\title{
Review Article \\ The Earliest Maya Farmers of Peten: New Evidence from Buenavista-Nuevo San José, Central Peten Lakes Region, Guatemala
}

\author{
Jeanette E. Castellanos ${ }^{1}$ and Antonia E. Foias ${ }^{2}$ \\ ${ }^{1}$ San Carlos University of Guatemala, 3 a Calle “A” 2-65, Z. 6, SMP, Colonia Villa de los Alamos, Guatemala City, Guatemala \\ ${ }^{2}$ Department of Anthropology \& Sociology, Hollander Hall 309, Williams College, 85 Mission Park Drive, Williamstown, \\ MA 01267, USA \\ Correspondence should be addressed to Antonia E. Foias; afoias@williams.edu
}

Received 27 June 2016; Accepted 26 September 2016; Published 15 February 2017

Academic Editor: Laura Del Puerto

Copyright (c) 2017 Jeanette E. Castellanos and Antonia E. Foias. This is an open access article distributed under the Creative Commons Attribution License, which permits unrestricted use, distribution, and reproduction in any medium, provided the original work is properly cited.

\begin{abstract}
The origins and cultural affiliations of the first sedentary agricultural and pottery-producing communities in the southern Maya lowlands remain hotly debated. Here, we describe the discovery of a new early farming settlement at the small site of BuenavistaNuevo San José on Lake Peten Itza in northern Guatemala. Evidence for a pre-Mamom occupation (1000-700 BC) at this site was found in the deepest fill layers overlying bedrock, including pottery diagnostic of this time period and the remains of a postin-bedrock dwelling. Because the evidence for this early settlement is from secondary contexts and because four radiocarbon dates cover a broad chronological range, the best evidence for the pre-Mamom occupation consists of the ceramics recovered in the excavations. The closest links of the pre-Mamom pottery at Buenavista-Nuevo San José are with the Eb complex at Tikal and the Cunil complex of Cahal Pech, Belize, suggesting strong interactions between these early groups. The discovery of preMamom pottery at Buenavista also suggests that the early farmers were more widespread than previously suggested. Furthermore, the presence of Olmecoid symbols incised on the pre-Mamom pottery at Buenavista-Nuevo San José indicates that these early communities were immersed in broad pan-Mesoamerican spheres of interaction.
\end{abstract}

\section{Introduction}

The origins of the first fully sedentary Maya communities of the southern Maya lowlands have garnered recent attention, as well as much debate [1-7]. In spite of recent efforts, evidence for the earliest agricultural pottery-making villages in central Peten, the heartland of Maya civilization, remains spotty and elusive. This has engendered discussion of the cultural affiliation of these first farmers and of their pottery traditions. Until the 1990s, the earliest Maya agriculturalists were thought to enter the empty Peten lowlands, expanding rapidly along rivers and lakes, starting around 1000 to 900 BC [8]. Such late dates for the transition to sedentism, agriculture, and pottery-making in the central Peten lowlands, in comparison to the rest of Mesoamerica, reinforced a general perspective that this region was last to be settled and tardy in adopting agriculture and pottery. The causes for this proposed late development were obscure although early scholars thought that the tropical forest environment was not conducive to agriculture and therefore permanent human habitation.

This early perspective on the first farmers of the central Maya lowlands has come under question. Here we will discuss several problems with this reconstruction and present new evidence from an early Middle Preclassic farming village at Buenavista-Nuevo San José on the north shore of Lake Peten Itza to shed further light on this debate. First of all, much recent environmental research contradicts such negative views of the Peten lowlands, pointing to the wealth of wild resources in a landscape that was dotted by lakes and marshes (present-day bajos, or seasonally flooded depressions) [9-12] .

Second, recent projects on the Archaic Period in Belize have shown that the region was populated, albeit sparsely, long before the first millennium BC $[1,7,13,14]$. Lohse 
et al. [14] summarize the record for the Paleoindian and Archaic occupation in Belize, while Lohse [1], as well as Clark and Cheetham [7], provide excellent reviews for the entire Maya lowlands (see also Rosenswig [15] for a review of the Archaic period for all of Mesoamerica). Pertaining to the three millennia between ca. 11,000 and 8,000 BC, a small number of fluted points (of the types called fishtail and flutedlanceolate, known broadly in North and South America) attest to the presence of highly mobile Paleoindian groups in north and south Belize $[7,14,16]$. New evidence from Western Belize caves, such as Actun Halal, has also been critical in supporting the presence of people from early on, at least in the eastern Maya lowlands [1,14]. Even more evidence for human presence comes from the Late Archaic Period (3400-900 BC) in Belize, suggesting increased population levels $[1,7,13,14]$ (see further discussion below). More recent evidence for early human occupation during this time period also comes from Blue Creek, northern Belize, where Beach et al. report that the earliest levels with lithics are directly above the oldest paleosol, are accompanied by abundant charcoal, and date to 2475-2195 BC ([17]: 171).

Third, the peopling of the lowlands before $1000 \mathrm{BC}$, is supported by paleoecological studies. At Cobweb Swamp in northern Belize, Jones [18] reports the appearance of manioc and maize pollen by $2500 \mathrm{BC}$, together with evidence for forest burning. At Pulltrouser Swamp, also in northern Belize, Pohl and her colleagues [19] recovered similar evidence of cultigen pollen and forest disturbance between 3400 and 3000 BC, with frequent maize pollen by 2400 BC. These scholars were able to establish that the earliest farming occurred in an environment still dominated by tropical forest, while more major forest disturbance and burning occurred much later, after 1500 BC ([19]: 362-363, 17; see also discussion in [1]:320). More recently, Lohse has excavated the Actun Halal rock shelter in the karstic uplands of the Macal river in western central Belize and encountered early maize and cotton pollen dating to 2210-1380 BC ([1]: 321-323). Dunning and colleagues [20] have identified a similar major environmental disturbance in their core in the Laguneta Tamarindito in the Petexbatun river valley between 4000 and $3000 \mathrm{bp}$ (or 2000-1000 BC), with jumps in grass pollen, significant carbon, decline in forest pollen, and some Zea pollen.

Paleoecological evidence for early occupation and agriculture in the Central Peten Lakes area has been available since the 1960s: lake coring in both Lake Petenxil and Quexil (south of Lake Peten Itza) documents Zea mays pollen together with an increase in grass pollen as early as $2000 \mathrm{BC}$ [21-25]. However, few radiocarbon dates, the possible "hard water lake error," and reliance on correlations with archaeological periods make this early placement of agriculture less reliable [26]. More recent paleolimnological studies from Lake Peten Itza have provided more fodder for debate. Curtis and his colleagues originally reported the first signs of forest removal around Lake Peten Itza as early as 3830 $\mathrm{BC}$, and more substantial forest disturbance (suggested by an increase in plant disturbance taxa and declining high forest pollen) beginning c. $2250 \mathrm{BC}$ ([27]: 146, 154; see also [28]). However, Mueller et al. [29] have revised this conclusion because, in the absence of Zea mays pollen (which first appears in their lake cores around $1000 \mathrm{BC}$ ), they argue that the vegetation change was caused by the "onset of climatic drying" (138) or what Rosenswig [15] discusses as the 22001900 BC drought. Nevertheless, Anselmetti et al.s soil erosion study of Lake Salpeten (directly east of Lake Peten Itza) records a tenfold increase in soil erosion rates starting at $2200 \mathrm{BC}\left(134 \mathrm{t} / \mathrm{km}^{2} \mathrm{yr}^{-1}\right)$ over the previous average in the preMaya gyttja (16.3 t/ $\left.\mathrm{km}^{2} \mathrm{yr}^{-1}\right)$ ([28]: 916). Although a drying episode leading to the disappearance of some high forest cover would have encouraged soil erosion, it is doubtful that it would have led to such a major increase by itself ([28]: 917; see also [30]). Hillesheim et al.s soil erosion study of Lake Peten Itza found a similar tenfold jump in soil erosion beginning $\mathrm{c}$. 3000 BC ([31]: 368). Beach et al.'s assessment of soil erosion rates in the central Peten lake cores also support a human role: "the early pollen evidence could be from the natural drying of the later Holocene, which was more conducive to savannas; yet as early as $1400 \mathrm{BC}$, upland erosion is finding its way into the lake basins and vegetation change shows widespread disturbance indicators" ([17]: 173). Thus, in spite of the lack of Zea pollen, other environmental indicators suggest anthropogenic environmental disturbance around the Central Peten Lakes previous to the first millennium BC (see similar discussion in [26]).

Furthermore, Wahl and Estrada-Belli have found maize pollen during the second millennium $\mathrm{BC}$ in the Holmul region of eastern Peten ([1]: 320), and, in a separate study, Wahl and his colleagues [11] discovered Zea pollen as early as 2650 BC in the Mirador Basin of northern Peten. Although only one grain was identified at this early date, it was associated with pollen of the Ambrosia genus, which consists of agricultural weeds like ragweed ([11]: 384-385). Mueller et al. [29] note a similar increase in Ambrosia associated with a radiocarbon date of 3470 cal yr BP (1520 BC) in their Lake Peten Itza cores ([29]: Figure 6). According to Wahl et al. ([11]: 385), the late appearance of Zea pollen in the Lake Peten Itza cores may be due to the pollen's larger size, which impedes it from travelling far from its source, so that lake cores removed from the shores or areas of cultivation may not preserve any sign of agriculture at this early time when much less agriculture was taking place. The presence of Zea mays pollen in both the Mirador Basin and the Holmul region not only attests to early human presence, but also implies that the opening of the Peten tropical lowland forest during this episode of climate drying in the Late Holocene may have made this zone more accessible to early farmers [11].

Contrary to the views of the Maya lowlands as vacant until $1000 \mathrm{BC}$, these paleoecological studies point to the presence of horticulturalists as early as 3000-2500 BC in some areas and by 1500 BC in other parts of the Peten lowlands. Northern Belize is the only region of the Maya lowlands from where we have substantial information on these early farmers (see below). Because domesticated plants are present in Belize from the fourth millennium BC on, Iceland [13], Clark and Cheetham [7], and Lohse et al. [14] refer to this period of the Late Archaic as the Early (3400-1900 BC) and the Late (1500900 BC) Preceramic. 
These scholars distinguish between the two time periods based on changes in lithic technology. The Early Preceramic is characterized by the introduction of macroblade technology which continues into Preclassic and Classic Maya times, supporting cultural continuity between the Archaic and Formative peoples [1, 13, 14, 32]. The Early Preceramic in Belize is also characterized by a particular point type tradition, called Lowe, and possibly also by Sawmill points $[7,13,14]$. These points have been discovered at a dozen sites in northern Belize $[7,13,14]$. Clark and Cheetham argue that the pattern of retouch on Lowe points suggests that they were hafted knives, a tool best suited to hunting ([7]: 304).

The Late Preceramic (1500-900 BC) is distinguished by the appearance of constricted unifaces which were used as general agricultural implements possibly for forest clearing and/or soil hoeing ([7, 14, 33], [1]: 327). These constricted unifaces/adzes are supplemented by a much larger variety of tools than in previous times, including scrapers, ground stone, hammer stones, small blades, and small oval bifaces discovered at numerous sites all over Belize $[1,7,13,14,19,34-$ 36]. Colha's Operation 4046 has substantial deposits from the Late Archaic [13, 14, 34]. The continuity in tool technologies at Colha from these preceramic levels into the Formative and Classic periods sustains the argument made by Iceland $[13,32]$ and Lohse [1] as well as Clark and Cheetham [7] for population continuity from Archaic into Preclassic times (see further discussion below). The shift in dominant tools from the Early Preceramic hafted knives to the Late Preceramic unifaces or adzes, together with the presence of ground stone in the latter period, indicates that subsistence turned heavily towards agricultural pursuits and should be described as collecting-horticulture $[7,15]$.

Even more recently, Rosenswig and his team have excavated additional Archaic settlements along the Freshwater Creek in northern Belize $[35,37]$. Rosenswig describes a Late Preceramic possible living site with patinated lithics, pits, and postholes associated with a buried orange aceramic soil stratum from Caye Coco in northern Belize [35]. Early AMS dates were obtained from carbonized wood in Pit Feature 2 in this stratum, 8320-6560 BP (6370-4610 BC), while Pit Feature 1 provided a more recent date 2790-2740 BP (840790 BC) [37]. More importantly, Rosenswig and his team extracted maize starch grains from all seven tested Archaic stone tools, with additional manioc, chili pepper, beans, and squash found only on some of these tools [37]. The presence of Zea starch on the Caye Coco tool associated with the dated Pit Feature 2 suggests that domestication was as early here as on the Gulf Coast and coastal Chiapas [37].

The mystery is that, elsewhere in the southern Maya lowlands beyond Belize, we have found rare traces of the settlements that correspond to these Late Archaic horticulturalists [14]. Outside Belize, Hansen and his team have excavated earthen floors overlying buried paleosols with postholes dug into bedrock at Nakbe in the El Mirador Basin, and the associated dates with this earliest occupation range from 1400 to 1000 BC ([38]: 55, Table 1). Hansen describes the ceramics found with these first constructions as "poor" which suggests that the pottery is rudimentary. Recently, Rice also reports early pottery and dates in association with the first construction episodes at Nixtun-Ch'ich' along the southwestern shore of Lake Peten Itza: in Mound ZZ1, the deepest fill level (Level AA) over bedrock was associated with two early radiocarbon dates of 1270-1010 BC and 1190920 BC (calibrated, 2 sigma) and contained 45 unslipped sherds, "much cruder than other pre-Mamom pottery" ([39]: 406). Clearly, with the presence of "rudimentary" pottery, these sites are at the transition between the Archaic and the Formative period, even though the radiocarbon dates still pertain to the Late Preceramic (which is why we describe these two sites in this section). Rosenswig [15] has put forth the possibility that the Peten horticulturalist-foragers may have been using wooden tools, which would make them archaeologically invisible.

One possible explanation for the rarity of Late Archaic sites outside Belize is that there were indeed few or no people in the rest of the Maya lowlands. However, we have argued against this position based on the overwhelming paleoecological evidence of environmental disturbance before 1000 BC. The rarity of Late Archaic archaeological sites in the rest of the southern Maya lowlands is understandable because these groups practiced agriculture within a broader huntingcollecting subsistence pattern and were probably mobile. This type of mixed subsistence (which combines collecting or foraging of wild resources with low-impact food production in small gardens with varied domesticated plant species) has been explored in much more detail beyond the Maya region [15, 40-42]. Any settlements pertaining to these horticulturalist-foragers or collectors would be small-scale, seasonal, and ephemeral. As such, these sites would leave few materials behind. These settlements would also lie deeply buried by later human activities and would have suffered major disturbances if not erasure at the hands of these later occupants, as several authors have pointed out $[1,17,35,37]$. In addition, at the moment, we have some evidence that these earliest lowlanders manipulated the bedrock to construct platforms [43], but such bedrock manipulations may be hard to identify in the small test pits that Maya archaeologists typically excavate down to bedrock. Another critical obstacle to the discovery of Archaic sites is that, in many parts of the southern Maya lowlands, substantial environmental changes at the beginning of the Holocene would have obscured early deposits under meters of sediments or water [19, 27, 44]. Pohl and colleagues [19] describe the consequences of global warming that characterized the early Holocene: rising sea levels caused a corresponding rise and alteration of inland rivers and shorelines; marine encroachment would have created more lagoons and marshes and would have increased sediment deposits along water courses and/or water bodies (see also [14]). For example, Anselmetti et al. have found that Lake Peten Itza has risen $56 \mathrm{~m}$ in height since the end of the last glaciation, suggesting that any early settlements may be underwater [44].

More importantly, the elusiveness of Late Archaic settlements in the Peten is comparable to the situation in other parts of Mesoamerica, including Laguna Catarina in central Veracruz and Laguna Pompal in the Tuxtlas Mountains, where the only evidence for these early inhabitants comes from Zea pollen in lake cores [15, 40]. Killion [40], Arnold 
III [41], and Rosenswig [15, 42] explain that the lack of settlements is due to the mixed subsistence pattern of these Late Archaic peoples whose mobility and low impact on the environment make them close to archaeologically invisible. These authors also suggest that such mixed subsistence continued much longer than previously believed, probably until the beginning of the Middle Preclassic c. 1000 BC when Mesoamerican peoples finally began to practice more intensive agriculture with maize as its staple. This transformation of the Mesoamerican subsistence system with maize as the central staple may have been predicated on the evolution of much more productive corn strains [15, 41, 42].

As the above short review suggests, we have many lacunae on the Late Archaic people in the southern Maya lowlands, which need to be filled by future research that targets specifically the earliest time periods of Maya history using appropriate geoarchaeological methods. In spite of these lacunae, substantial new research, both paleoecological and archaeological, suggests that the southern Maya lowlands were inhabited, albeit sparsely, by horticulturalist-foragers as early as the fourth millennium BC in some parts and as late as the second millennium $\mathrm{BC}$ in other parts. These horticulturalist-foragers were highly mobile, did not make pottery, and lived in small ephemeral settlements which would be hard to identify archaeologically.

\section{Continuity or Intrusion among the First Pottery Producers?}

The first ceramic-making, sedentary, agricultural settlements do not appear in the southern Maya lowlands until the transition between the Early and Middle Preclassic, c. 1100900 BC. Four pottery traditions identify these first sedentary farmers: the Cunil in the Belize Valley of central Belize; the Swasey of northern Belize; the Xe in the Pasion region; and the Eb of central and northern Peten. These four first ceramic traditions precede the well known pan-Maya Mamom ceramic horizon. They have been considered highly divergent and, in some cases, even proposed to be non-Maya by some authors [5, 45-48].

The Swasey complex from Cuello in northern Belize was originally championed as the earliest lowland Maya pottery from c. 2000 BC, but these dates were later revised to $1200-$ 1000 b.c. [49-55]. However, due to the presence of waxy slips and forms characteristic of the Mamom horizon (e.g., cuspidor), the Swasey complex is now placed by Clark, Cheetham, Inomata, and colleagues slightly later than the other three pre-Mamom traditions, around 850 b.c. [4, 7, 43]. Lohse ([1]: 330-336) also confirms this interpretation in his review of 32 radiocarbon essays from Cuello, which concludes that the pre-1000 BC dates probably pertain to the Late Archaic. The Swasey tradition is now recognized to encompass the pre-Mamom occupation not only at Cuello, but also at nine other sites along the river systems of northern Belize, including Colha, Nohmul, Blue Creek, Kichpanha, San Estevan, and Pulltrouser [7].

In the Pasion river valley, the earliest pottery was documented at Altar de Sacrificios and Seibal (also Ceibal) in their Xe and Real phases, respectively, generally placed between 900 and $600 \mathrm{BC}[46,56]$. However, both Adams and Sabloff argue that Altar's Xe complex began after Ceibal's Real occupation: Altar's Xe pottery is most similar to the Late Real assemblage at Ceibal, in that it has a higher frequency of waxier over dull slips, a preference for black slips over white slips, and common shallow vessels $[43,46,56]$. Few other sites in the Pasion region have Xe pottery, and then only a handful of sherds: Punta de Chimino, Itzan, and Caobal near Ceibal $[43,57,58]$.

More recent excavations at Ceibal by Inomata and his colleagues have dated the Real complex much more accurately between 1000 and $700 \mathrm{BC}$, based on a suite of new radiocarbon dates associated with dozens of building floors [2, 43]. Equally important, this new research has allowed Inomata et al. to divide the Real complex into three facets: Real 1 (1000850 BC), Real 2 (850-800 BC), and Real 3 (800-700 BC) [43]. Real 1 is distinguished by the high preference for dull whiteslipped (Huetche) and dull red-slipped (Abelino) pottery, the use of postslip incisions, and the production of simple forms (tecomates, round-side bowls, and necked jars, among which some have exteriorly folded or bolstered rims) [43]. Real 2 is marked by the continuation of these features, but whiteslipped pottery declines in frequency, and more thick-walled vessels appear [43]. This facet is also characterized by the appearance of bowls with wide everted and grooved rims, but in low frequencies [43]. Real 3 is transitional to Mamomsphere traditions: postslip incision is replaced by preslip grooving and chamfering, slips become more glossy, black slipped pottery increases in frequency, shallow plates are very common, and, finally, finger-nail impressions on unslipped or partially red-slipped vessels make their first appearance [43]. Due to these new excavations, for the first time, the Real time period is not an unchanging unitary time block, but, instead, we can examine internal dynamics within this early time period, at least at Ceibal (see further discussion below).

In the Belize Valley, the Cunil tradition was the last to be discovered among the four earliest pottery traditions. It was defined at Cahal Pech by Awe and Cheetham [4, 59-61] and later identified at other sites in the same region, such as Blackman Eddy, Xunantunich, Pacbitun, and Barton Ramie [4, 6, 7, 62-64]. The dates of the Cunil complex have varied, with some scholars reporting the range between 1100 and $900 \mathrm{BC}$ (calibrated, as given in 62 and 64). Lohse, Cheetham, and Clark favor a later starting date of 1000 BC $[1,4,7]$. Finally, Cheetham reports five calibrated dates from the Cunil building platforms at Cahal Pech which range (within 1sigma) between 1200 and 795 BC ([4]: 30, Table 3.1). These dates make Cunil close to contemporary with the Real-Xe ceramic sphere of the Pasion region.

The fourth and final tradition, the Eb, extends over central and northern Peten, including Tikal (where it was originally defined by Culbert) and Uaxactun; Ixtinto and Yaxha Hill near the Yaxha-Sacnab Lakes; Trinidad de Nosotros, Ixlu, and Nixtun-Ch'ich' near Lake Peten Itza; Holmul and Cival north of the Central Peten Lakes; and Nakbe in northern Peten [4, 7 , 23, 65-72]. The Eb tradition appears slightly later than Cunil because some of its forms and decorative attributes are closer to Mamom $[4,67]$. Here, we describe the discovery of another 
Eb settlement at Buenavista-Nuevo San José on the north shore of Lake Peten Itza.

The reporting of the chronology of these earliest ceramic traditions has been problematic, as both calibrated (marked by capital letters BC or BP) and uncalibrated dates (marked by lower case letters b.c. or b.p.) have been published without attention to this distinct notation. However, Lohse [1] provides a rigorous review of the pre-Mamom radiocarbon dates from Belize and their archaeological contexts. He concludes that claims for the beginning of pre-Mamom pottery traditions before $1000 \mathrm{BC}$ are unlikely because of stratigraphic inconsistencies, problematic contextual associations, and/or the probable mixing of old carbon in later deposits [1]. For example, at Cuello, the earliest dates from Burial 179 and 62 may be preceramic as these interments had no pottery nor were they clearly associated with dateable constructions ([1]: $330-336)$. The other pre-1000 BC assay from Cuello is from charcoal recovered in the lowest paleosol at the site, but this may be old carbon from presettlement natural fires which was reincorporated into this ancient stratum [1]. Blackman Eddy produced only one pre-1000 BC radiocarbon date of $1400-$ 1048 BC (Beta-122281), while the other pre-Mamom assays from this site cluster tightly between 1000 and 800 BC [62], so Lohse suspects that the earliest date may be from "old, perhaps Archaic carbon that was incorporated" into the later midden deposit found in the chultun BR-F3 ([1]: 337). The earliest dates from Cahal Pech (Beta 77207, 1307-996 BC; Beta 77204, 1214-537 BC) are more accurately associated with preceramic or precultural paleosols above bedrock, rather than from Cunil-phase deposits, so the foundation of the sedentary pottery-using settlement probably also begins after 1000 BC ([1]: 337-338).

Before the 1990s, when substantial new research revealed the Archaic roots of northern and central Belize (as described above), the dominant perspective was that these first ceramic traditions originated elsewhere, in the Chiapas, Guatemalan, or southeastern highlands from where proto-Maya or MixeZoquean speakers brought pottery, agriculture, and sedentism [45-48, 73]. For example, Andrews [45] points to ceramic similarities between Xe pottery and Isthmian ceramics (such as dull, powdery slips, an emphasis on white slips, and the presence of tecomates and other simple forms). Similarly, Sharer and Gifford [47] connect the Jenney Creek complex of Belize Valley with Chalchuapa pottery. Even more recently, Ball and Taschek have also argued that the Cunil and the subsequent Jenney Creek traditions of the Belize Valley pertain to non-Maya groups, possibly Mixe-Zoquean speakers, migrating from the southeastern Maya highlands [5]. These two authors point to the rarity of types and wares typical of the subsequent Mamom ceramic tradition and instead argue that the dominant types and wares (such as Jocotal Orange-Brown and Mars Orange) of the Jenney Creek complex have direct connections with Chalchuapa. They believe that these dominant wares represent non-Maya groups intermixed with Maya communities which produced the Mamom-tradition types [5].

Lohse has provided a recent review of these diffusionist arguments, concluding that the supporting evidence is weak or has been overturned ([1]: 315-317). For example, the identification of loan words from proto-Mixe-Zoquean into Maya dialects [74] and glottochronological studies of the timing of the splintering of the Maya language family around $1400 \mathrm{BC}$ [75] were thought to support the migration of the first Maya groups into the lowlands from the highlands, bringing with them both agriculture and pottery-making towards the end of the second millennium BC. More recent linguistic data have put into doubt these perspectives: the timing of the Mixe-Zoquean linguistic borrowing has now been placed in the Late Preclassic, and not around 1000 BC $[1,76]$, while the assumption behind glottochronology (that languages change at a steady rate) is now untenable $[1,77]$.

In opposition to the "diffusionists," Cheetham and colleagues argue that even though there are differences between these complexes (especially in their unslipped pottery), more similarities unite them and these similarities are the precursors to the full blown Mamom tradition, which all scholars recognize as culturally Maya $[4,7,60,61,67]$. In fact, Cheetham sees sufficient ties between $\mathrm{Xe}, \mathrm{Eb}$, and Cunil to identify them all as pertaining to a Cunil horizon $[4,60,67]$. Clark and Cheetham interpret these early traditions as tribal territories of groups of "similar language and culture," that is, Maya ([7]: 297). Although Culbert ([78]: 54) disagrees with Clark and Cheetham [7] and sees little connection between the four earliest ceramic traditions of the Maya lowlands, he does agree that these represent autochthonous developments within the Maya lowlands because there are no sufficient similarities connecting these complexes and the pottery of any other Mesoamerican region.

The connections between $\mathrm{Xe}, \mathrm{Eb}$, and Cunil (the earliest of the four pottery traditions) include the emphasis on unslipped pottery ( $>48 \%$ of these earliest traditions), a high preference for red slips (>16\%), and a lower preference for black, white, orange, and brown slips $[4,7]$. Altar de Sacrificios is exceptional in having a much larger component of black slipped pottery than the other complexes of the Cunil horizon: $24 \%$ versus $3-6 \%$ at Cahal Pech, Tikal, and Ceibal [4]. The two Pasion sites are also slightly different in having more white-slipped ceramics, probably due to stronger interaction with nearby Zoque groups in the Chiapas highlands where white pottery was dominant [4]. An additional link between $\mathrm{Xe}$, Cunil, and $\mathrm{Eb}$ is the nature of the slips: all slips are dull and less often have a low luster but are not waxy or highly polished as the later Mamom and Chicanel pottery [4]. Furthermore, slip color is generally uneven or variegated [4]. Nevertheless, it is important to note that this pottery, at least in the Cunil and $\mathrm{Eb}$ spheres, does not represent a rudimentary technology as most sherds evince a high-firing "metallic" sound when dropped. Other scholars have also pointed to a well-developed Cunil pottery technology, lacking signs of experimentation $[59,62]$. Shared vessel forms by the $\mathrm{Xe}, \mathrm{Eb}$, and Cunil traditions also suggest that they represent closely related cultural groups. All three regions produced '“mushroom stands', chalice-shaped censers, pot stands or ceramic stools, and plates, dishes, bowls and tecomates (neckless jars) with bolstered rims" as well as colander bowls ([4]: 30). Among these shared forms, the most distinctive is the plate or dish with a wide everted rim $[4,7,60,67]$. Inomata et al. note slight differences between the Real and 
Eb everted rims and the Cunil ones from Cahal Pech: the rims from the Pasion and central Peten tend to have sharper junctures with the walls, beaded lips, and circumferential grooving, while the Cunil examples tend to have a smoother juncture, direct lips, and postslip incised designs [43]. This kind of close connection between the $\mathrm{Xe}$ and $\mathrm{Eb}$ ceramic traditions suggests that strong interactions occurred between central Peten and Pasion settlements as much as between central Peten and the Belize Valley.

A final, but important, connection between these three early traditions is the use of postfire, postslip incision, generally of simple geometric designs, but sometimes of more complex ones, such as avian serpents, flame eyebrows, lightning, crosses, clefts, shark teeth, and music brackets $[4,60]$. These symbols are well known in Formative Mesoamerican archaeology because they are part of a pan-Mesoamerican symbolic complex, often associated with the Olmec sites of San Lorenzo and La Venta [4, 6, 60, 79-81]. The presence of these symbols on pre-Mamom pottery in the southern Maya lowlands testifies to the involvement of these early Maya in interregional interaction networks, contrary to previous interpretations of their isolation from the rest of Mesoamerica at this early time. Even though the incised symbols pertain to a pan-Mesoamerican interaction sphere, their precise form on the pre-Mamom pottery has a distinct Maya flavor, according to Cheetham [4], as well as Garber and Awe [6]. Although an important diagnostic of the pre-Mamom pottery traditions, postslip incision appears in only c. $3-5 \%$ of these assemblages ([4]: 30, Table 3.2). In spite of their low incidence, the specificity and similarity of these incised symbols across the Cunil, $\mathrm{Xe}$, and $\mathrm{Eb}$ communities speak to a high degree of integration between them: "Specific motifs bear an uncanny likeness from community to community, are usually the same size, and were ordinarily incised in the same place on the same kinds of vessels. This not only attests to a shared tradition and frequent interaction, it indicates a common belief system predating the Mamom era" ([4]: 31). This is strong evidence that all the pre-Mamom communities of the southern Maya lowlands pertain to one culture.

The Swasey tradition seems to be the least similar to $\mathrm{Xe}-\mathrm{Eb}$-Cunil and lacks the pan-Mesoamerican symbols and many of the other diagnostics of the Cunil horizon, but it is the one most similar to the later Mamom tradition, so it cannot be seen as non-Maya either [4, 7]. The similarities between the earliest $\mathrm{Xe}-\mathrm{Eb}$-Cunil traditions and their connections with the subsequent Mamom horizon suggest that their makers were culturally Maya and predecessors to the later pottery traditions of the Maya lowlands from Mamom on. Further supporting evidence is brought to bear by the figurine assemblages from these sites, which, according to Cheetham, "share several stylistic features, including overall size, hairstyles, jewelry, even body painting, scarification, or tattoos" ([4]: 34).

Coming from a different perspective, Lohse anchors his argument for autochthonous development in the southern Maya lowlands to the continuity of stone technology, settlement location preference, and subsistence patterns from the Late Archaic through the Cunil and Jenney Creek Mamom periods in the Belize River Valley (and to a lesser extent, lowland Guatemala) [1]. Such continuity supports the Maya cultural identity of the earliest farmers of the Eastern lowlands, without denying that the widely separated groups in Belize, the Pasion river valley and central-northern Peten, were isolated enough from each other and in contact with nearer non-Maya populations to produce some pottery unique to each group.

These scattered and scarce discoveries of pre-Mamom pottery across the Maya lowlands are generally interpreted as representing tribal societies consisting of simple egalitarian villages, lacking any kind of public architecture or social ranking [82-84]. This perspective has been overturned by the most recent research at Ceibal and Cahal Pech, where the preMamom Real and Cunil phases show clear signs of public architecture and/or differential access to resources, exotic goods, and pan-Mesoamerican symbols [2, 7, 60, 63, 85, 86].

The recent excavations of Inomata, Triadan, and their team at Ceibal have been the more spectacular $[2,43,86]$. They have discovered the earliest E-group in the Maya lowlands dated to the beginning of the Real phase, c. 1000950 BC. The E-group consisted of a western square building, nicknamed Ajaw (carved into the natural bedrock and covered by black clayey soil; measuring $2 \mathrm{~m}$ in height and $4 \mathrm{~m}$ in the eastwest direction at its summit), and an eastern long rectangular platform, nicknamed Xa'an (also carved out of the natural bedrock; measuring $1 \mathrm{~m}$ in height and $42-55 \mathrm{~m}$ in length in the northsouth direction) [43]. The back wall of Xaan was faced with limestone blocks, while two steps allowed access to its front summit [43]. The Ajaw building was renovated at least twice during the Real phase, reaching 3-5 m in height between 850 and $800 \mathrm{BC}$ and possibly as much as 6$8 \mathrm{~m}$ by $700 \mathrm{BC}$ [43]. Twenty caches, mostly of greenstone axes, were exposed beneath the multiple plaza floors of the Real phase E-group [2, 86]. Two additional large platforms were built during the Real phase to the southwest and northeast of the E-group. The SW mound (Sulul) was rebuilt at least 17 times during the Real phase, until reaching a height of $3.5 \mathrm{~m}$ by the end of the Real 2 phase ( $800 \mathrm{BC}$ ) and roughly $6 \mathrm{~m}$ by the end of the pre-Mamom period, and at least $34 \mathrm{~m}$ in width in the eastwest direction $[2,43]$. The NE platform (K'at) was renovated at least 15 times until reaching $2-2.3 \mathrm{~m}$ in height by the end of the pre-Mamom period [2, 43]. The K'at platform and possibly both the K'at and Sulul platforms may have supported residences of perishable materials [2, 43]. Also noteworthy is that both were built with dark clay that may have been brought from the nearby wetlands; if true, it would suggest considerable labor investment in their construction [2]. Such substantial building projects from $1000 \mathrm{BC}$ on do not hint at an egalitarian society but point to more complex hierarchical systems. Less than ten years ago, the earliest Maya of the Real, Xe, Swasey, and Eb phases was seen as a simple farmer living in modest houses in small villages. Now, based on the new Ceibal discoveries, this perspective is untenable. This does not mean that small simple villages did not exist; they did, such as the one at Cahal Pech, Blackman Eddy, Cuello, or Buenavista-Nuevo San José as described in this article.

In contrast to the early ceremonial architecture at Ceibal, Cahal Pech (the other archaeological site with substantial 
and well documented pre-Mamom occupation) was a small village of some 75 to 150 people during the Cunil phase ([63]: 108). The Cunil deposits were discovered deeply buried under Str. B4 and Plaza B. The first sign of occupation was a living surface overlying the buried paleosol which included quantities of chert debitage but lacked ceramics, except for small sherds on its top surface ([63]: 105-107). The first construction consisted of an oval platform, Str. B-4/13-sub, which was $0.48 \mathrm{~m}$ tall at its south end and merged with the natural hill at its north end; it was associated with a posthole and drain, suggesting that it supported a perishable structure on top [63]. The second platform (B-4/12-sub) rose $0.84 \mathrm{~m}$ high on its south side, was circular in plan, and had two small steps attached to its south end. The third stage of construction involved the formation of a patio to the south of Str. B-4/11sub which was connected to this courtyard via a $20 \mathrm{~cm}$ high riser which was plastered with lime, the earliest use of lime plaster at the site [63]. The fourth stage of construction took place in the Late Cunil and comprised four renovations to the lime-plastered building platform positioned along the north edge of the patio. While the first one (10a-sub) was equally simple as the previous ones, the subsequent three renovations became more elaborate: 10b-sub was bilevel, with its interior floor recessed $0.5 \mathrm{~m}$ lower than the exterior of the platform; $10 \mathrm{c}$-sub involved the elevation of the interior recessed floor by $30 \mathrm{~cm}$, the addition of lateral benches, and the decoration of its exterior superstructural walls with vertical red stripes; 10d-sub had two poorly preserved floors with only one posthole, so its architectural plan is unknown $[60,63]$. The domestic nature of these platforms is underscored by the amount of trash found within their fill, in their patios, and on their interior floors [87]. These residences disappeared at the end of the Cunil period when they were covered by temples built throughout the subsequent Middle Preclassic to Late Classic [63, 87]. Three other Cunil residences were excavated under Plaza B, but these had simpler architecture: no plaster, nor recessed interior floors, nor painted walls ([63]: 108). However, the interior floors of some of these structures and their patios were paved with limestone slabs or cobbles [63]. These residences also disappeared at the end of the Cunil phase to make space for the first lime-plastered version of Plaza B [63]. Aside from their architectural elaboration, the B-4 substructures also enjoyed more access to fine pottery incised with pan-Mesoamerican symbols and jewelry made of imported marine shell and jade, as well as figurines $[4,7,60,87]$. The high labor investment in the B4 substructures and their higher access to exotic goods and symbols mark their residents as higher status than everyone else at Cahal Pech. This points to the beginning of social inequality, although whether it was achieved or inherited remains unclear $[7,60,64]$.

Powis and Cheetham point out the important transformation that occurs at Cahal Pech at the end of the Cunil phase: the residences of the first elites become the site's first temples [87]. These scholars find this same pattern at other early sites (although more evidence for the nature of these earliest buildings would be welcome): at Blackman Eddy where Cunil-phase domestic platforms were found underneath Pyramid B1; at Xunantunich where a Cunil-horizon sheet midden was discovered above bedrock underneath Str. A-6; at Tikal where Eb materials were excavated in chultuns or "problematic deposits" underneath the North Acropolis and Mundo Perdido; at Uaxactun where Eb remains were identified under Str. A-1 in the South Court; and at Holmul, where Cunil ceramics were unearthed deep under Str. B in Group II. However, Ceibal represents a second pattern distinct from the one described by Powis and Cheetham: around $1000 \mathrm{BC}$, Ceibal was founded as a ritual center on virgin ground, or rather virgin bedrock, from which the first ritual buildings were shaped to form the earliest E-group known in the Maya lowlands [2]. Regardless of whether occupation at these early sites began as residences or religious architecture, evidence from both Ceibal and Cahal Pech suggests that life in these pre-Mamom communities was much more complex than previously described.

The general perception that the pre-Mamom Maya were sedentary has also come under scrutiny. Inomata and his colleagues have recently proposed that the nomadic lifestyle did not end abruptly at the beginning of the Real phase at Ceibal [43]. While the first version of the E-group was built at the beginning of Real $1(1000 \mathrm{BC})$ and rapidly rebuilt to larger dimensions during the Real 1 and 2 times (1000-800 BC), no residences were found to belong to these two centuries in spite of significant fieldwork by both the Harvard project in the 1960s and Inomata and Triadan's project in the 2000s ([43]: 4272). The only possible exception is the SW platform Sulul, but it is unclear if its function was ritual or domestic at this time [43]. Even if we accept Sulul as residential, it implies that, between 1000 and $800 \mathrm{BC}$, only a small group became sedentary, while the rest of Ceibal's population maintained their more mobile lifestyle. As no other site in the whole Pasion region shows ceramic use until the Real 3 phase (800$700 \mathrm{BC}$ ), it is quite likely that, for the first two hundred years of the first millennium $\mathrm{BC}$, the Maya of this region continued to practice their mobile horticultural-foraging lifeways [43]. The kind of post-in-bedrock simple dwellings that are found in these early settlements represents such little labor investment that Inomata and his colleagues conclude that "inhabitants moved their residences frequently" in the pre-Mamom times [43]. One could argue that this does not necessarily mean that they were mobile, but it does support Inomata et al's interpretation that it represents a higher level of mobility than in subsequent time periods when the Maya began to build and rebuild their houses on platforms and in the same locations [43]. The slow development of sedentism in the Pasion region stands in contrast to Belize, where villages like Cahal Pech and Cuello were sedentary from early on, possibly as early as the beginning of the Cunil phase or right after, with rapid evolution from postin-ground dwellings to house platforms $[7,50,60]$. The picture painted by these discoveries at Ceibal and the Belizean sites is that the Agricultural Revolution was an uneven and slow process in the Maya lowlands: small sedentary groups coexisted with larger mobile groups for longer periods of time than originally believed, minimally 200 to 300 years [43]. A second important conclusion of Inomata et al.s research at Ceibal is that the first Maya ceremonial architecture was built 
mostly by mobile horticulturalist-foragers, rather than sedentary agriculturalists [43].

In spite of these recent discoveries and paleoecological studies, the earliest farmers of central Peten are still poorly known as most of the new research has taken place in the Pasion region and the Belize River Valley. We contribute to this scholarship by describing a newly discovered preMamom Eb-sphere site at Buenavista-Nuevo San José on the north shore of Lake Peten Itza. In an effort to make this time period better known, we focus on the early pre-Mamom pottery discovered at this site, and its affinities with the first pottery traditions in central Peten, Pasion, and Belize. We also report new radiocarbon dates for this early time period in central Peten. Although neither the radiocarbon dates nor the stratigraphy of the site permit us to claim that this village marks the beginning of the sedentary pottery-producing Mayas of Central Peten, there are enough diagnostic ceramic markers to suggest that our excavations uncovered remains from such an early occupation disturbed by the later Maya of the Middle and Late Preclassic periods.

\section{Buenavista-Nuevo San José}

The archaeological site of Buenavista-Nuevo San José, in Peten, Guatemala, was first identified in 2000 in the settlement survey of the southern periphery of Motul de San José by the Motul de San José Archaeological Project (MSJAP) of Williams College, directed by Antonia Foias (Williams College) and Kitty Emery (Florida Museum of Natural History, University of Florida-Gainesville) [88-91]. The earliest excavations at Buenavista took place in 2001 and showed that the site had a lengthy occupation from the Middle Preclassic (c. 600-300 BC) until the Early Postclassic (c. 1000-1200 $\mathrm{AD})[88,92]$. The discovery of Mamom pottery in the lowest levels led the senior author to expand excavations at the site in $2005[93,94]$. The 2005 field season recovered significantly more data on the first settlers of the region through excavations of the Middle Preclassic substructures identified in 2001 underneath the Late Classic occupation in the largest structure at the site, Str. 4, as well as in the deepest levels on the perimeter of the site, behind Strs. 2, 7, 8, and 11 .

The small site of Buenavista-Nuevo San José is located $0.5 \mathrm{~km}$ north of the northwestern shore of Lake Peten Itza in northern Guatemala (Figure 1), at the UTM coordinates N1881550 and E1991250. It was part of a larger settlement which was partially destroyed by modern construction in the hamlet of Nuevo San José and by the intensive agricultural and cattle ranching activities of its inhabitants. The site is positioned on a high hill above Lake Peten Itza: from the top of Str. 4, one can see a considerable portion of the lake, as well as the Twin Pyramids of Motul de San José towards the north. The location of Buenavista-San José conforms closely to the settlement location preferences of Middle Preclassic groups across the southern lowlands, and especially in the Central Peten Lakes region, where Rice has also found the earliest settlements in the Lakes Yaxha-Sacnab on high hills around the two lake depressions [23].

In its final Late Classic form, Buenavista-Nuevo San José was composed of 14 mounds, divided into two formal plaza

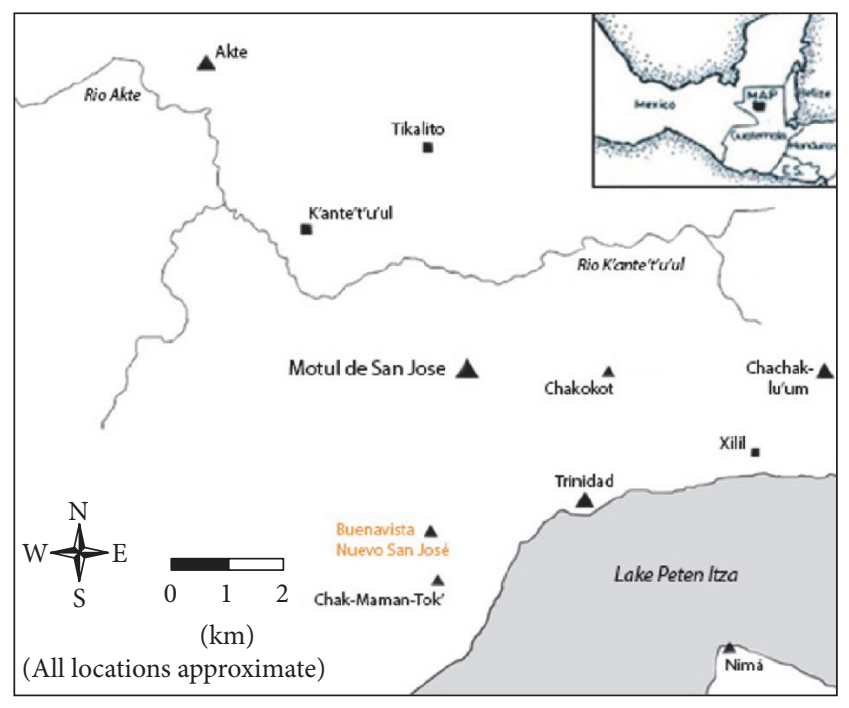

FIgURE 1: Map of the Motul de San José region, showing the location of Buenavista-Nuevo San José (modified after Moriarty [90]: 32, Figure 5).

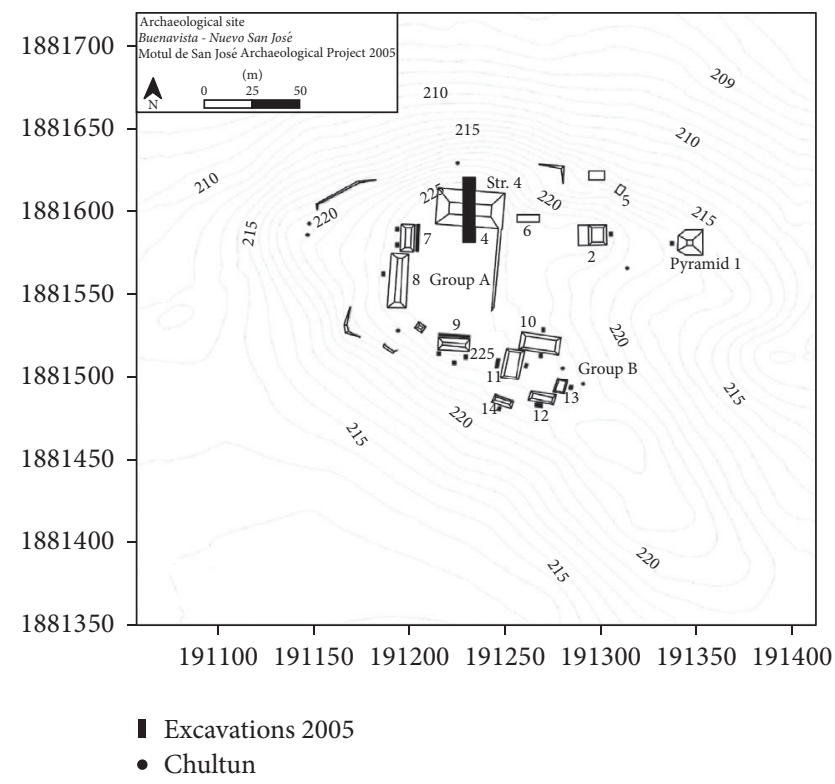

Figure 2: Map of Buenavista-Nuevo San José, Peten, Guatemala, showing structures and excavations (Moriarty et al. 2005).

groups (Group A to the northwest, and the smaller Group $\mathrm{B}$ to the southeast) and a few additional isolated mounds to the northeast of Group A (Figure 2). The only temple-shrine identified at the site (Str. 1) lies to the far east of Group A, in an isolated down-hill position, quite distinct from the usual Late Classic pattern, and was built during the Late Classic to Early Postclassic times [94]. It contained a looted mortuary chamber, as expected of eastern shrines during Late Classic times. Seven chultuns surround the mounds. The generous size of Plaza A suggests that it had a more public role, while the small scale and more private nature of Group B indicates a more residential function. None of the mounds surrounding 
TABle 1: Radiocarbon AMS dates from Buenavista-Nuevo San José (Calibration based on Stuiver and Reimer [149], Reimer et al. [150] and using OxCal internet vers. 4.2).

\begin{tabular}{|c|c|c|c|c|c|}
\hline Sample number & Provenience & Material & $\begin{array}{l}\text { Uncalibrated } \\
\text { date }\end{array}$ & $\begin{array}{c}\text { Calibrated } \\
\text { date, } 2 \text { sigma }\end{array}$ & $\begin{array}{c}\text { OxCal } \\
\text { calibrated } \\
\text { date, } 2 \text { sigma }\end{array}$ \\
\hline AA72325 & $\begin{array}{l}\text { Fill used to level } \\
\text { bedrock }\end{array}$ & Carbon & $2493 \pm 34$ & $780-420$ BC & $788-508$ BC \\
\hline AA72323 & $\begin{array}{l}\text { Below and within } \\
\text { 4Sub-1 }\end{array}$ & Carbon & $2467 \pm 35$ & $760-415$ BC & $766-430 \mathrm{BC}$ \\
\hline AA72324 & $\begin{array}{l}\text { Fill above stuccoed } \\
\text { floor of } 4 \text { Sub-1 }\end{array}$ & Carbon & $2500 \pm 35$ & $790-420 \mathrm{BC}$ & 791-511 BC \\
\hline AA75154 & Fill of 4 Sub-3 & Carbon & $2449 \pm 34$ & $750-410$ BC & $755-410 \mathrm{BC}$ \\
\hline
\end{tabular}

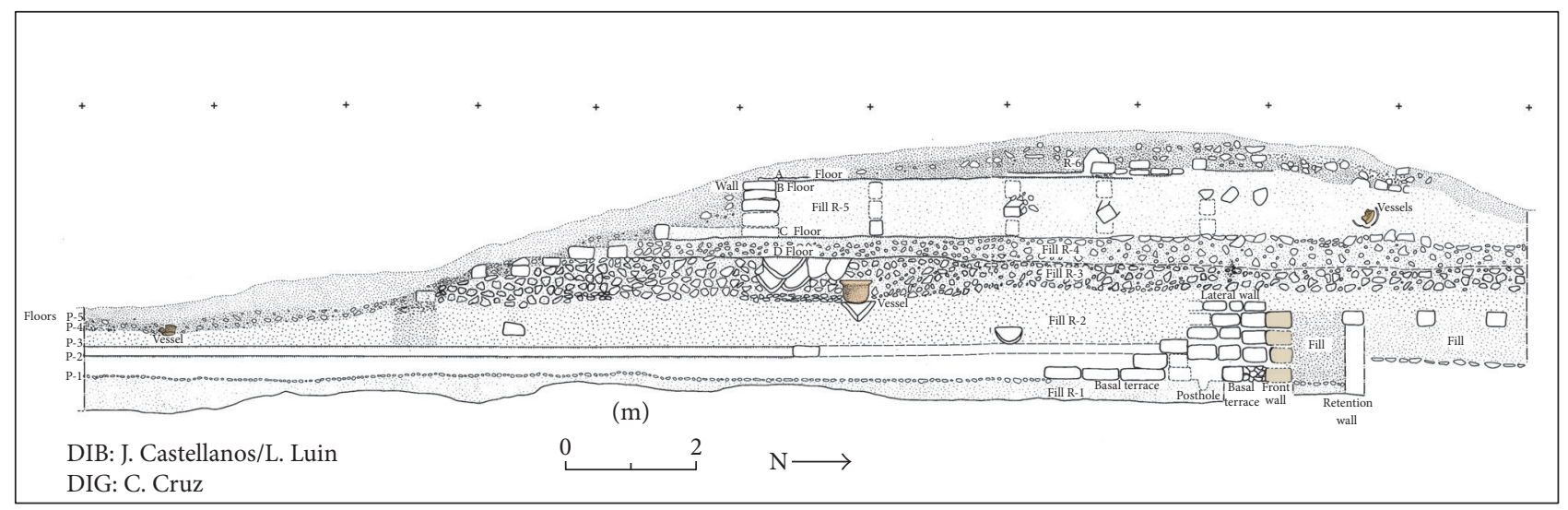

FIGURE 3: West profile of trench in Str. 4.

these plazas are monumental. Str. 4 is the largest and sits along the northern limit of Group A. It measures $22 \mathrm{~m}$ long by $16 \mathrm{~m}$ wide and $4 \mathrm{~m}$ high. Slightly higher than Str. 4 , the eastern pyramid, Str. 1, measures $20 \mathrm{~m}$ long by $20 \mathrm{~m}$ wide and $6 \mathrm{~m}$ high. The rest of the mounds are less than $1 \mathrm{~m}$ in height.

\section{Excavations of the Early Architecture in Structure 4}

Because details of the excavations at the site have been presented elsewhere $[93,94]$, we will focus here on the major locus that produced the majority of evidence for the preMamom occupation, Structure 4, which was excavated by the operation TBV1A. Four AMS radiocarbon dates were analyzed at the University of Arizona and anchor the ceramic analysis in absolute time (Table 1). The excavation of Str. 4 was carried out using an axial trench oriented northsouth, $22 \mathrm{~m}$ long by $1 \mathrm{~m}$ wide and $4 \mathrm{~m}$ deep, which ended at bedrock (Figure 3). This trench encompassed units 115 through 126. The excavation uncovered three substructures within the final Late Classic mound, as well as three postholes in the bedrock at the base of the trench.

The first evidence of human occupation consists of three postholes dug into bedrock. These were found directly in front, or to the south, of the first stone-and-earth platform, substructure 4Sub-1 (Figures 3 and 4). These postholes may be the remains of an ephemeral post-in-ground dwelling of the pre-Mamom phase because they are too close to the edge of 4 Sub- 1 to have been part of 4 Sub-1. In addition, they are not arranged in a line as would be expected if they were connected to 4 Sub-1. Due to time limitations, we were not able to explore further the bedrock surrounding these three postholes.

The first major construction episode at this locus was the leveling of the hill's irregular limestone bedrock, with a layer of fill (R-1), consisting of brown clay with few small stones, approx. $6 \mathrm{~cm}$ in thickness. The topmost surface of this fill was a highly compacted earthen floor (Figure 3 ). The radiocarbon date AA72325 places this initial major construction between 780 and 508 BC (see Table 1). This layer of fill, R-1, contained significant amounts of pottery diagnostic of the pre-Mamom $\mathrm{Eb}$ and Cunil ceramic traditions but mixed with Mamom pottery types, the latter approximating $5 \%$ of these lots (see Table 2).

On top of this earliest fill R-1, the ancient Maya initiated the building of the first substructure, 4Sub-1, on the highest point of the hill. The section of substructure 4Sub-1 that we excavated is a segment of the front of the platform which sits on top of a $20 \mathrm{~cm}$ high basal bench extending out approx. $50 \mathrm{~cm}$ (Figure 4). The platform is built using roughly cut limestone blocks, and then lime plastered. It is approximately $1.5 \mathrm{~m}$ high.

In the west profile of the trench, we uncovered another segment of 4Sub-1, a later addition, which consisted of a terrace extending southward from the façade of 4 Sub-1, and 
TABle 2: Frequencies of Mamom and pre-Mamom groups and wares in the deepest levels of units TBV1A-115 to 125 (lots included: Unit 115-7,8,9,10; U.116-7,8,9; U.117-8,9; U.118-7,8,9,10; U.119-8,9; U.120-6\{2\},7,8,9,10; U.121-8,10,11,12; U.122-9; U.123-9 to 17; U.124-6,7,8,9\{1,2\}, $10\{1,2\}, 11\{1,2\} ; \mathrm{U} .125-3,4)$.

\begin{tabular}{cccccccccc}
\hline & Unslipped & $\begin{array}{c}\text { Mamom } \\
\text { waxy types }\end{array}$ & $\begin{array}{c}\text { Mars } \\
\text { Orange }\end{array}$ & $\begin{array}{c}\text { Uck } \\
(\text { Red })\end{array}$ & $\begin{array}{c}\text { Cocoyol } \\
(\text { Cream })\end{array}$ & $\begin{array}{c}\text { Chi } \\
(\text { Black })\end{array}$ & $\begin{array}{c}\text { Ainil } \\
(\text { Orange) }\end{array}$ & Other minor types & Total \\
\hline$N$ & 2663 & 293 & 40 & 668 & 176 & 963 & 596 & 139 & 5538 \\
$\%$ & $48.1 \%$ & $5.3 \%$ & $0.7 \%$ & $12.1 \%$ & $3.2 \%$ & $17.4 \%$ & $10.8 \%$ & $2.5 \%$ & $100 \%$ \\
\hline
\end{tabular}

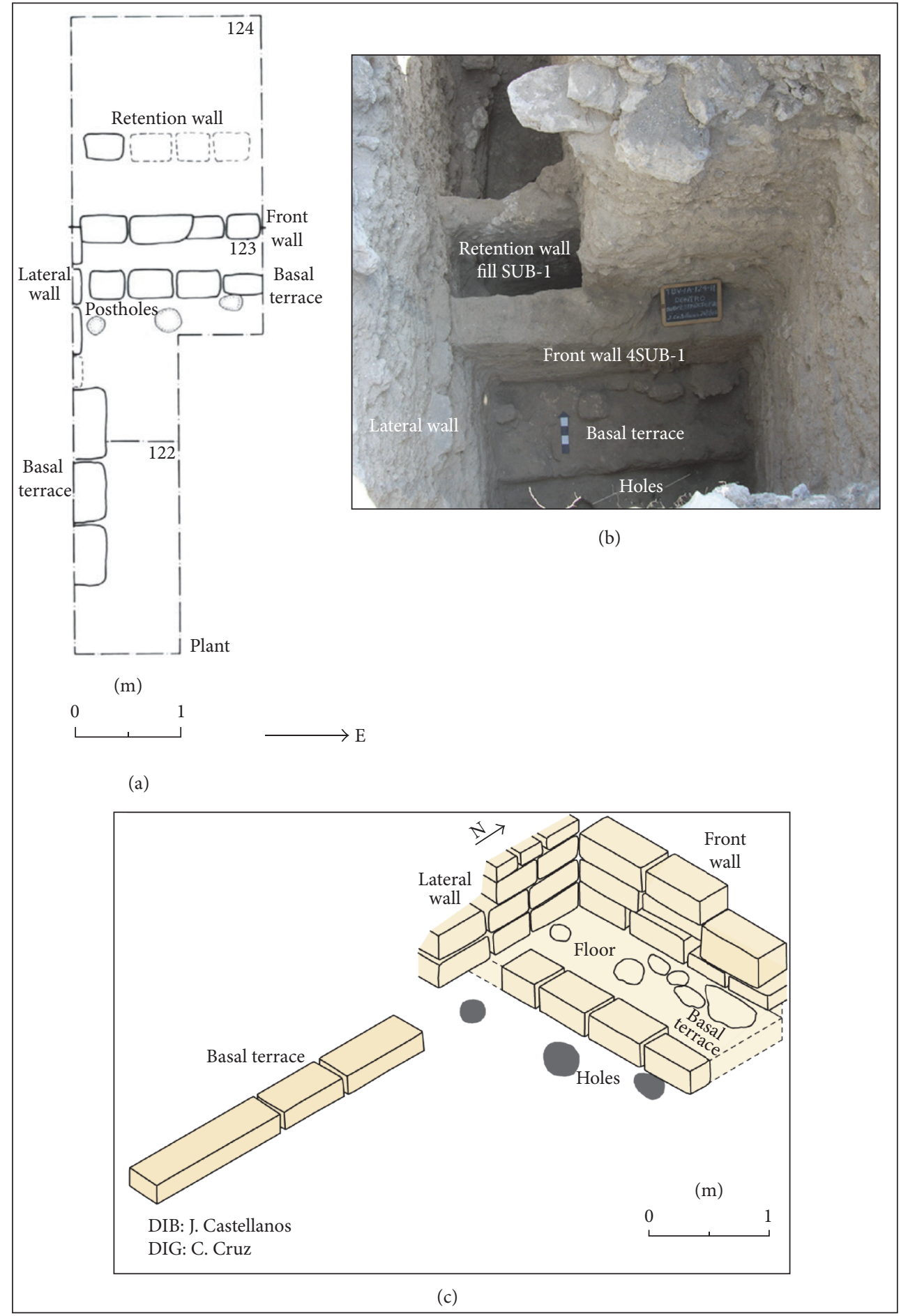

Figure 4: Substructure 4Sub-1: (a) plan; (b) photograph showing architectural features of 4Sub-1 and the three postholes excavated into bedrock in front of the substructure; (c) reconstruction. 


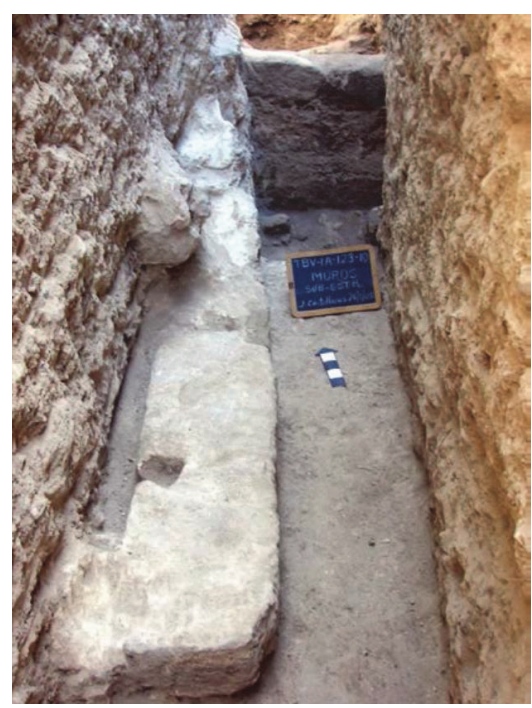

FIGURE 5: The lateral platform and lateral basal bench or moulding of 4Sub-1.

was also placed on top of a basal bench extending almost $2 \mathrm{~m}$ out from 4Sub-1; four enormous limestone blocks formed the eastern edge of the lateral basal bench (Figures 4 and 5). Alternatively, this lateral bench may represent the remains of a dismantled outset staircase that provided access to the top of 4Sub-1.

Excavations within 4Sub-1 revealed a construction technique based on fill boxes (see Figures 3 and 4). This first substructure was associated with a plaza approximately $72 \mathrm{~m}^{2}$, which was stuccoed during two renovations (Floors P-2 and P-3 in Figure 3). The first renovation covered the earlier earthen plaza floor with a thick stucco floor, approx. 30$40 \mathrm{~cm}$ thick, which was extremely hard and compact. This stucco floor buried the lateral and frontal basal benches of substructure 4Sub-1. A third stucco floor was added, also thick $(20 \mathrm{~cm})$ and hard, at some later point during the Middle Preclassic.

The architecture of this first platform building, 4Sub-1, indicates that these early farmers had already developed (or acquired) sophisticated knowledge of engineering, limestone quarrying, stucco production, and so on. The architectural style of substructure 4Sub-1 is similar to Middle Preclassic architecture at Nakbe [38, 72]. Hansen describes similar small platforms at the latter site where the architecture from 800 BC (or later centuries) "consisted of low, vertical stone walls forming small platforms with roughly shaped, flat, rectangular stones. These walls range from three to five courses high and about half a meter in height" ([38]: 56).

The excavation of the fill of substructure 4Sub-1 recovered a carbon sample (AA72323) which was dated to cal. 760-415 BC (see Table 1). This fill had the highest density of preMamom pottery, underscoring the presence of early human activity at this site, even though our evidence is from later Middle Preclassic fill deposits. Together with the pre-Mamom pottery, we also encountered fragments of solid modeled figurines (none complete) (Figure 6), lithic fragments, and a broken bark beater (Figure 7(c)).
The exact dimensions of substructure 4Sub-1 are unknown as our excavations were limited. The platform was at least $2.14 \mathrm{~m}$ wide in the northsouth direction. Nevertheless, we suggest that it was $\mathrm{T}$-shaped because of the additional terrace extending southward in front of the structure (which we are calling the lateral terrace in Figure 5). Its height for the Middle Preclassic (Mamom horizon) of $1.5 \mathrm{~m}$ and the presence of a large stuccoed plaza in front of it suggest that 4 Sub-1 had a nonresidential function.

Substructure 4 Sub- 1 and its plaza were then covered by another substructure 4 Sub-2 and a new plaza Floor P-4 (see Figure 3). This second substructure was built using two different fill layers. The first fill, R-2, covered the previous 4Sub-1. It consisted of yellowish sand mixed with clay, which was tightly compacted. This type of fine fill suggests that 4Sub-1 was intentionally and carefully buried rather than dismantled. We recovered a carbon sample from this layer which was dated to cal. 788-508 BC (sample AA72324, see Table 1). The second fill, R-3 (lacking any floor separating them), was composed of medium and large stones contained within construction boxes and sealed by stuccoed Floor D (see Figure 3). In total, these two fill levels raised the height of the mound by another $1.3 \mathrm{~m}$. Under Floor D, we found a dedicatory cache which consisted of a complete deep unslipped bowl, approx. $50 \mathrm{~cm}$ high, with a similar diameter placed along the northsouth axis of the building (visible in Figure 3 below slab stones in R-3 in the middle of the profile; see also Figure 8). This bowl is of the pre-Mamom Eb type Calam Buff, which is very common at Tikal. However, this cache pertains to the Mamom phase, suggesting that Calam Buff continues to be used in Mamom times, or that this new building 4Sub-2 dates to the transition from pre-Mamom to Mamom times. Within the R-2 and R-3 fill layers, faunal remains were recovered, including Strombus pugilis, Oliva sayana, Pomacea flagellata, and Unionidae bivalves which regularly only appear in Middle Preclassic contexts [93]. We also recovered modeled solid figurine fragments, ceramics pertaining to the Mamom horizon, and a number of chert instruments such as hammerstones, utilitarian bifaces in celtiform or triangular form, abundant used chert flakes, and fragments of prismatic obsidian blades, possibly from the El Chayal and San Martin Jilotepeque sources in the Guatemalan highlands [93]. An almost complete bark beater was also found in this fill level (Figure 7(b)). Although their main function has been suggested to be paper production, more recently, McAnany has proposed that they may have been used to make cloth at least during the Preclassic when they are much more frequent and more broadly distributed than in the Classic period [95].

Substructure 4Sub-2 underwent an additional modification during the Middle Preclassic, where fill level R-4 raised the height of the platform, and was sealed by stucco Floor C (see Figure 3). The fill of 4Sub-2 also had a good amount of pre-Mamom pottery. The quantity of early pottery in the fill of substructures, 4Sub-1 and 4Sub-2, reaching over 5,000 sherds, suggests that the pre-Mamom occupation at Buenavista-Nuevo San José was substantial.

In the posterior section of substructure 4Sub-2, we found a possible termination cache, consisting of two partial and 

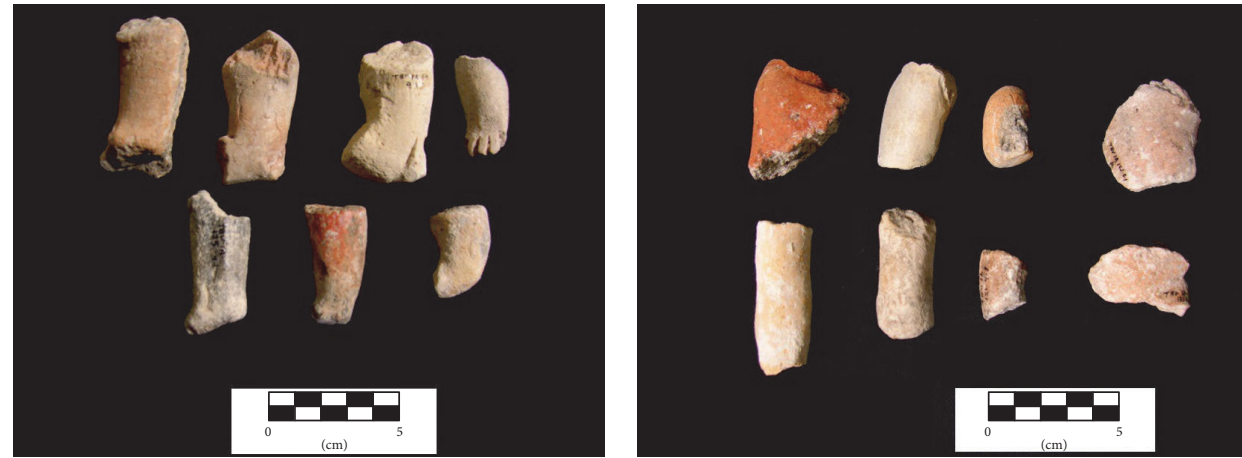

FiguRE 6: Figurine fragments from the deepest fills in Str. 4.
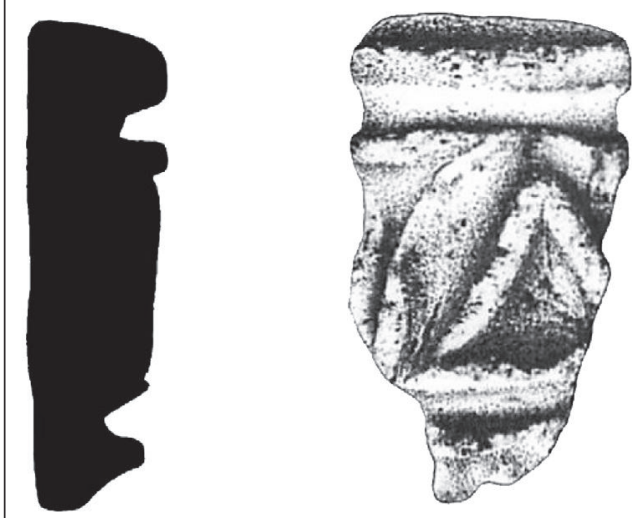

DIB: L. Luin

DIG: C. Cruz

FOTO: J. Castellanos
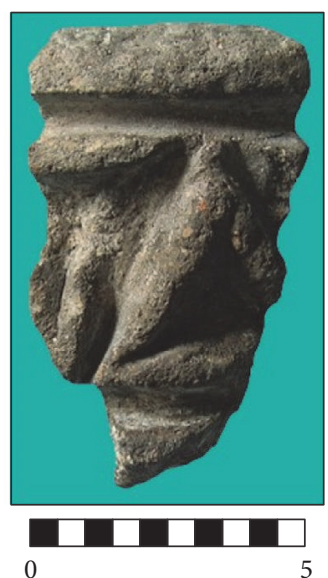

$(\mathrm{cm})$

(a)

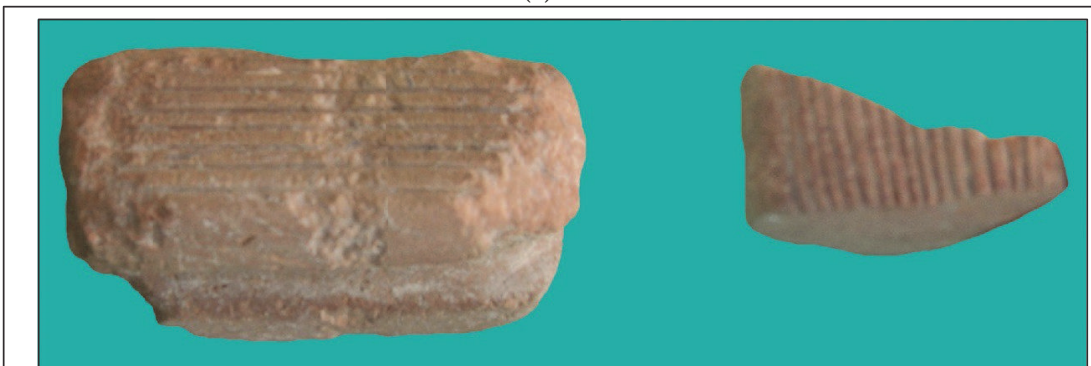

(b)

DIB: L. Luin

DIG: C. Cruz

FOTO: J. Castellanos

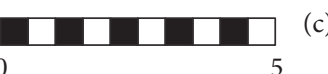

(cm)

FIGURE 7: Other artifacts found in the deepest fill levels: (a) stamp; (b), (c) bark beaters from fill of 4Sub-2 and from fill of 4Sub-1, respectively.

highly fragmented vessels of the Middle Preclassic types Desprecio Incised and Pital Cream (Figure 9; see also Figure 3). Neither the façade of this substructure nor its extent could be observed in the profile of the excavated trench, possibly because it was dismantled during antiquity. Substructure 4 Sub-2 reached a height of approx. $1.7 \mathrm{~m}$ above the plaza floor
(Floor P-4) and extended minimally $16.9 \mathrm{~m}$ in the northsouth direction.

The presence of the two caches associated with 4 Sub-2 is of particular interest. Garber [96] discusses ancient Maya traditions of including whole vessels and other valuables in dedicatory rituals to buildings, while termination rituals 

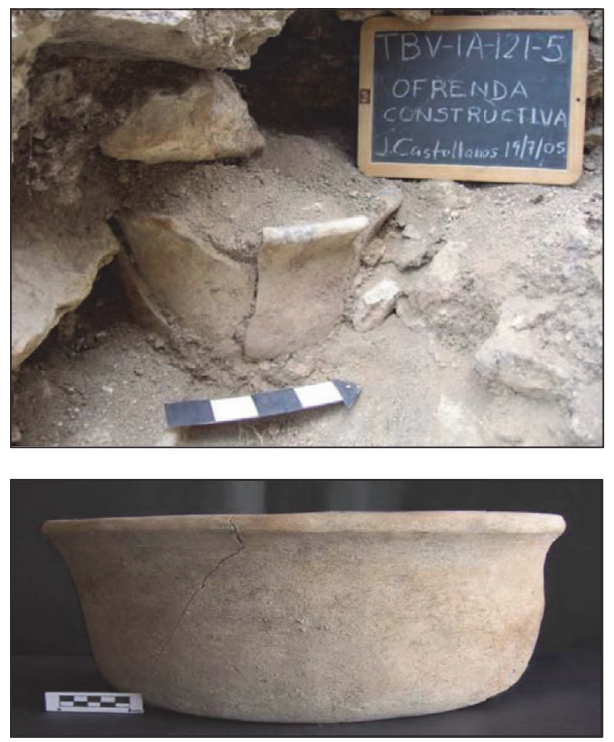

FIGURE 8: Dedicatory cache of substructure 4Sub-2 and its vessel Calam Buff.
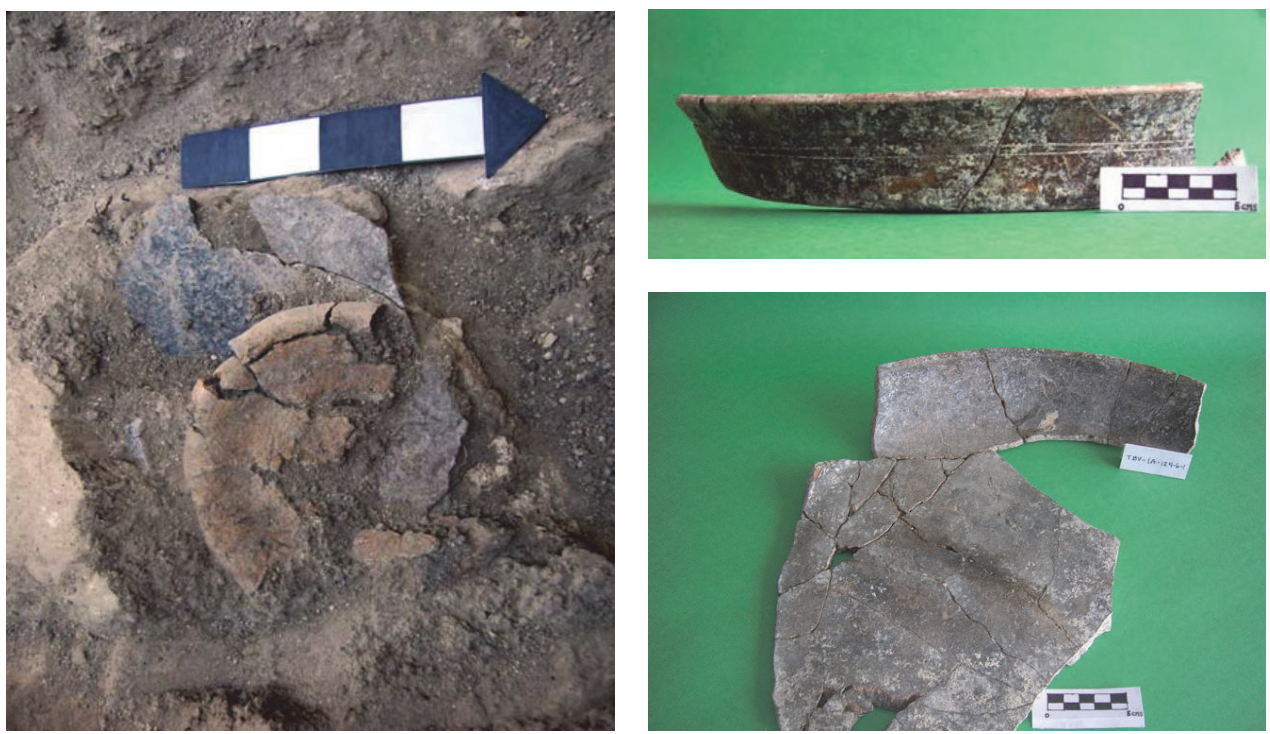

FIGURE 9: The termination cache of substructure 4Sub-2 and one of its two vessels, a Desprecio Incised dish.

included incomplete vessels, a tradition that is characteristic of the Classic period but has deep roots [97-100], as seen in this Middle Preclassic construction at Buenavista-Nuevo San José. The two caches indicate continuity in such rituals from the Middle Preclassic through the Postclassic.

Probably towards the end of the Middle Preclassic, the mound underwent a third construction, 4Sub-3, which raised the mound at least another meter, with a front wall of 5 courses of stones that varied from well-cut to amorphous (approx. $1.4 \mathrm{~m}$ high), and whose fill (R-5) was sealed by stucco Floor B (see Figure 3). The ceramics found in this layer of fill included diagnostic types of the Mamom horizon although, in the top part of the level, there were also a few examples of the Sierra, Polvero, and Flor ceramic groups of the Late
Preclassic Chicanel horizon. A carbon sample from the fill R5 of substructure 4Sub-3 (AA75154) provided the fourth date for the site, calibrated to 2 sigma, 750-410 BC (see Table 1).

The exact dimensions of substructures 4 Sub- 2 and 4 Sub3 are unknown due to the limited scope of our excavations, although both appear to have been rectangular in shape. Both were modified during the Late Classic through the addition of a staircase along the front of the mound and of several walls and two stucco floors on top of the mound. These were minor modifications and most of the height and volume of this structure pertains to the Middle Preclassic.

Apart from the three substructures of Str. 4, other deposits pertaining to the Middle Preclassic were identified under the Late Classic buildings, based on their associated 


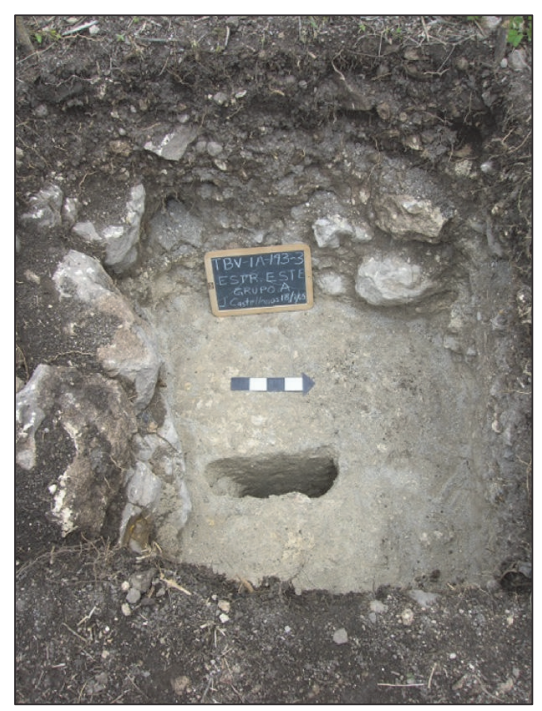

(a)

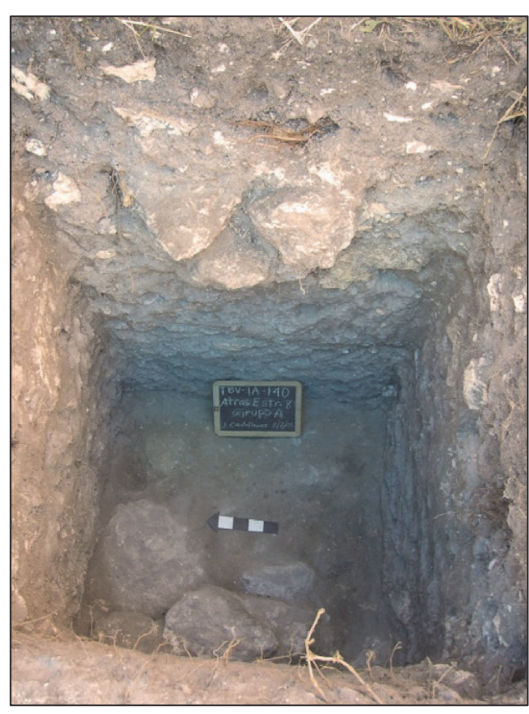

(b)

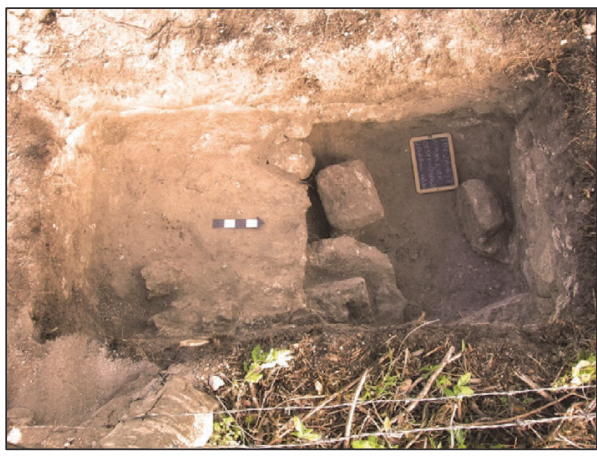

(c)

Figure 10: Remains of deeply buried Middle Preclassic platforms behind Structure 2 (a), Structure 8 (b), and Structure 11 (c).

ceramic materials. Strs. 2, 8, and 11 all had low Middle Preclassic platforms in the deepest sections of the test pits $[93,94]$ (Figure 10). Two noteworthy artifacts were recuperated from these excavations, found in the lowest fill deposits overlying bedrock. Although unclear if it is of pre-Mamom or Mamom date, half of a hollow cylindrical seal attests to the decoration of bodies, clothing, and/or paper using this instrument, which is very similar to an example from Uaxactun in the Ceramoteca of the Institute of Anthropology and History, Guatemala City (Figure 7(a)). In addition, a segment of the flat base of a Chi incised plate with a black-brown dull slip was found. This plate is extraordinary because its interior base is decorated with a postslip, finely incised quadripartite motif (Figure 11), a symbol which appears at Tikal during the Eb phase and which pertains to a pan-Mesoamerican ideological interaction sphere, often associated with the Olmec culture $[4,6,60,67]$.

All four radiocarbon dates from the excavations of Str. 4 pertain to the time period between the eighth and fifth centuries BC. These dates suggest that the site underwent a major transformation at the beginning and/or during the Middle Preclassic, with the construction of three structures along the north edge of the largest plaza at the site, Plaza $A$, and four other smaller structures around this plaza. However, the presence of postholes in the bedrock below the lowest substructure of Str. 4 and the ceramics found in the construction fill of this same structure tell us that a settlement of pottery-producing farmers existed at this site earlier based on the presence of significant diagnostic pre-Mamom types, and we now turn to this topic in the rest of the article.

\section{The Pre-Mamom Pottery of Buenavista-Nuevo San José}

The first level of the analysis of the pottery from this site follows the framework of the type-variety-mode classification system established by Gifford and his colleagues and used broadly in the Maya lowlands to establish cultural chronologies and interaction between sites [101-108]. Due to the fragmentary nature of the pre-Mamom pottery of Buenavista-Nuevo San José, we prefer to describe the ceramic assemblage by ceramic group. A significant obstacle to quantifying the frequency of the pre-Mamom pottery is that eroded body sherds of the waxy Mamom types are indistinguishable from body sherds of the matte pre-Mamom types. Here, we base our description on rims and bases. The identification of the types and groups of the pre-Mamom pottery was facilitated by an evaluation of the BuenavistaNuevo San José collection by Cheetham in Guatemala in 2006 and to his careful comparative study of the ceramic complexes pertaining to this time period, including Cunil, Eb, Ah Pam, $\mathrm{Xe}$, and Swasey in the southern Maya lowlands [4, 60, 67].

Due to the close similarities between the BuenavistaNuevo San José and Tikal early pottery, we have retained as much as possible the names of the types given to the Early Eb phase at Tikal by Culbert $[65,66]$ and Laporte and Fialko $[109,110]$, although some of the types have been reclassified by Cheetham to more accurately represent their fit within the pre-Mamom Cunil sphere [4, 61, 67]. We propose to define a pre-Mamom Eb ceramic sphere to which the earliest pottery at Buenavista and Tikal belongs. This Eb ceramic sphere has close connections with the Cunil ceramic tradition in slips and ceramic forms, but not in pastes $[4,5,68]$, and we leave it to future scholars to determine whether the Eb and Cunil ceramic traditions are close enough to belong to one larger ceramic sphere as Cheetham suggests [4]. We also see connections between the Buenavista pottery and the Pasion region as suggested originally by Rice for other Central Peten Lakes sites $[68,69]$. We feel it is very important to present a more extended discussion of the diagnostic types of the pre-Mamom phase found at Buenavista-Nuevo San José for a number of reasons. First, because the pre-Mamom pottery has been defined recently, it is not well known. Second, because this material is scarce and often mixed 

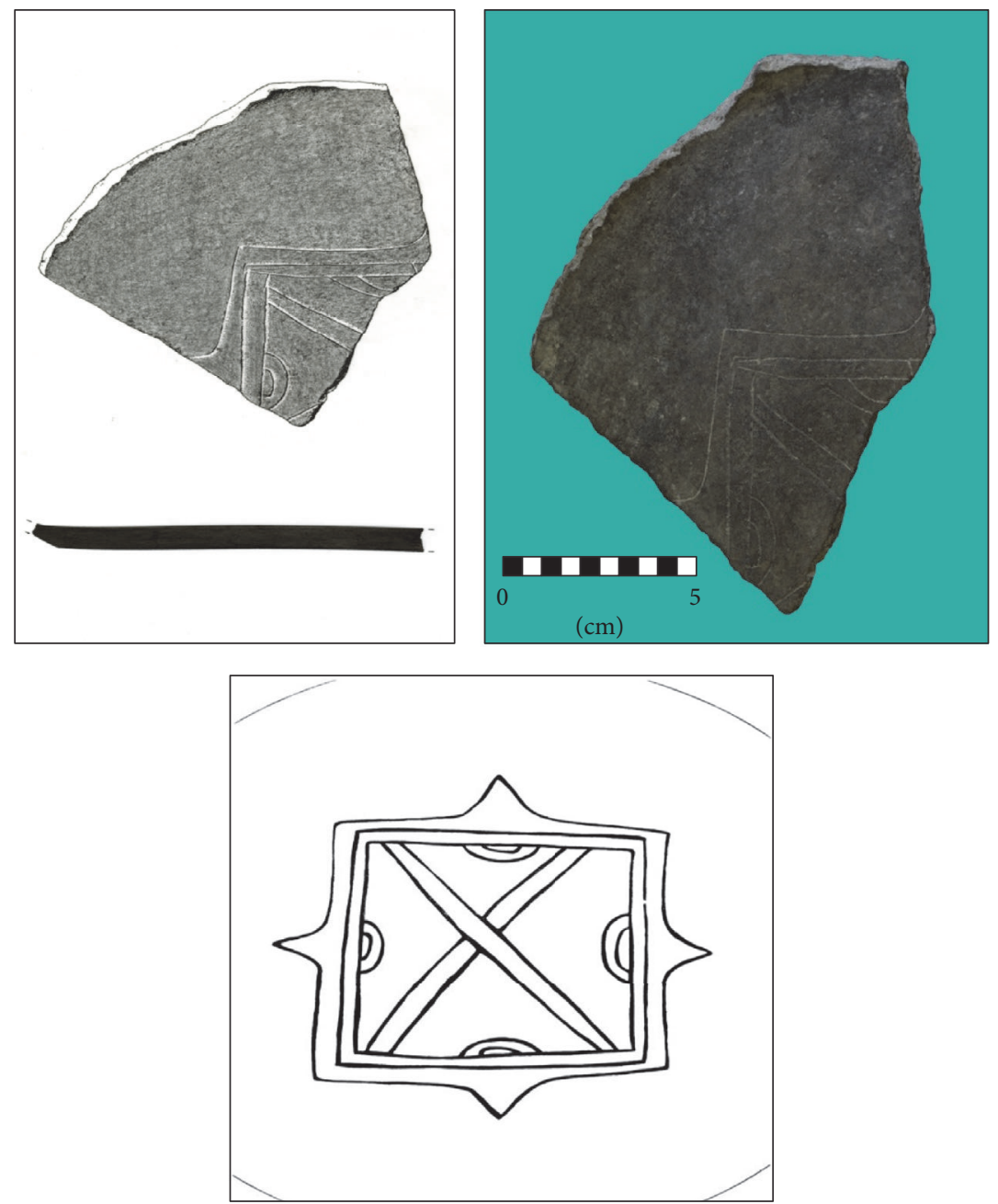

FIGURE 11: Fragment of a Chi incised plate with a postslip incised quadripartite motif and its hypothetical reconstruction.

with later Mamom materials, at least in central Peten, its detailed description will help other scholars identify it in their excavations. Finally, there is a great deal of confusion about this pre-Mamom phase in the central-northern Peten because in the original description of this pottery at Tikal, Culbert, assigned the collection the same names as the Mamomsphere types (but see reclassification in Cheetham [67]).

\subsection{General Characteristics of the Buenavista Ceramic Com-} plex. The pottery pertaining to the pre-Mamom horizon at Buenavista-Nuevo San José has been named the Buenavista ceramic complex. It was found mixed with Mamom types in the deepest fill layers on top of bedrock, as well as in the fill of the first two substructures of Str. 4 (4Sub-1 and 4Sub-2). The pre-Mamom pottery represents $95 \%$ of the pottery in the deepest fill deposits, with Mamom types encompassing the other $5 \%$ (Table 2).

The pre-Mamom Buenavista ceramic complex consists of sherds with red, black, streaky orange, cream to white, and buff slips which have an opaque-dull quality, varying from matte to slightly polished. These nonwaxy slips are the most important distinguishing feature from the later Mamom pottery. This slip quality is not due to erosion but rather to the intentional production of such slips as suggested by the fact that most of the early pottery is fired to a high temperature evidenced by the metallic sound the sherds make when dropped. In spite of the high temperature firing, the preMamom assemblage from Buenavista is also characterized by uneven firing as the pottery presents frequent black clouds, streakiness, discolorations, and uneven slip color. These features indicate that this pottery is not the work of the earliest inexperienced potters, but rather of those who have had time to experiment and become accomplished, as noted by other scholars $[4,7,60-63,67]$. This pre-Mamom Buenavista ceramic complex also included unslipped pottery, although, at Buenavista-Nuevo San José, it was not always easy to distinguish it from the later Mamom Achiotes group. Finally, the assemblage also included a unique group of sherds with volcanic ash and gray-orange in color. Due to its rarity at Buenavista-Nuevo San José, it may be an import, possibly from the Belize Valley [61]. It should be made clear from the outset that apart from these few sherds that may be imports from Belize Valley, the rest of the assemblage has distinct pastes from those of the Cunil complex at Cahal Pech, and 


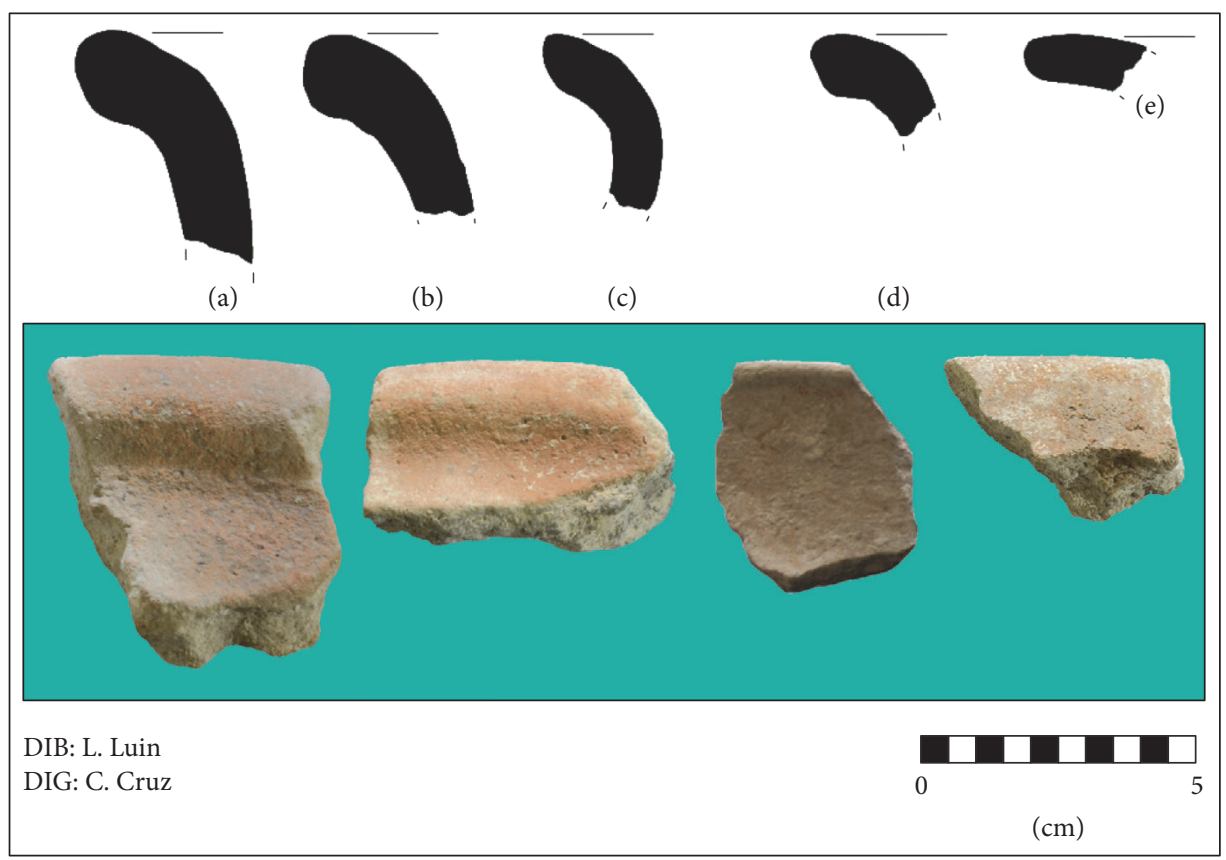

FIGURE 12: Canhel Unslipped.

we think that they were locally made, although we have yet to carry out chemical sourcing studies.

The decoration found on some of this pre-Mamom pottery consists of postslip fine incision, although there are also preslip incisions, grooving, and fluting/chamfering but less frequently. While postslip, postfire incision is characteristic of the Cunil ceramic tradition, the latter four decorative modes are characteristic of the end of pre-Mamom ceramic traditions and the transition to the Mamom horizon. The presence of all five decoration techniques among the pre-Mamom pottery at Buenavista-Nuevo San José suggests that the site may have been occupied throughout pre-Mamom times (1000/950 to $700 \mathrm{BC})$.

Only a small number of shapes are represented in the preMamom assemblage at Buenavista-Nuevo San José: plates and dishes with wide everted rims; bowls or dishes with bolstered rims, flared or incurved walls, and flat or rounded bases; vases with direct rims, vertical walls, and flat bases (more rare); jars with bolstered rims and long outcurved necks; tecomates with direct or bolstered rims, strongly incurved walls, and flat or rounded bases; a ritual mushroom stand, with nail impressions on its superior surface. All these forms are characteristic of the pre-Mamom Cunil ceramic tradition as defined by Cheetham and his colleagues $[4,7,60$, $61,67]$ and closely resemble the forms of Early Eb at Tikal as defined by Culbert and refined by Cheetham [65-67].

The overall impression of the pre-Mamom pottery from Buenavista is that it is decorated less frequently than early materials at Tikal and Cahal Pech, especially among the unslipped pottery where incision, excision, zonal brushing, grooving, and partial red slip on rims are found on a good number of the unslipped vessels [61]. Also, in contrast to Tikal, the Buenavista-Nuevo San José early pottery tends to have specific forms produced in only one type with only one paste, and different from other types (compare the forms and pastes of Canhel, Calam, and Unnamed Thin Red Paste, in the descriptions below).

Two wares are found at Buenavista-Nuevo San José: Uaxactun Unslipped [111] and Belize Valley Dull [59, 61]. The first ware is slightly more dominant than the second (Table 2), a feature typical of pre-Mamom assemblages in the Maya lowlands [4]. Five ceramic groups fall within the Uaxactun Unslipped Ware: Canhel (Unslipped); Calam (Buff); Cabcoh (Striated); Unnamed Unslipped Thin Red Paste (probably Kolok Red); and Unslipped Impressed. The Belize Valley Dull encompasses the slipped serving ware pottery and has been divided into six ceramic groups: Uck (Red), second most common; Ainil (Orange), frequent; Chi (Black), most common; Boolay (Brown), rare; Cocoyol (Cream), rare; and Unnamed Volcanic Ash (Gray-orange) Group, very rare. The frequencies of the pre-Mamom wares and/or groups found at Buenavista-Nuevo San José are given in Table 2.

5.2. Unslipped Pottery. The Canhel (Unslipped) ceramic group was established by Culbert $[65,66]$ at Tikal (Figure 12). Like most pottery in the unslipped ware, it has a coarse paste that includes coarse crystallized calcite in the majority of cases. The paste is light pinkish-brown-buff (5 YR 5/8, 6/4, 6/6; 7.5 YR $6 / 3$ to $7 / 4$ ), with red and black ferruginous inclusions, although some examples also have quartz. A good portion of these vessels have a thin dark core. Some closed body sherds had black clouding on their exterior, possibly from their use for cooking, or due to uneven firing. No decoration was discerned on the Canhel pots. Surfaces were smoothed, but not very carefully, as on some examples, we noted light marks from the smoothing instrument used. Unfortunately, 
we were not able to distinguish well between Canhel and the Mamom type Achiotes Unslipped, so this description probably is narrower than the true range of this type at the site.

Basically, two forms were found at Buenavista-Nuevo San José: a deep bowl with everted rim, $22 \mathrm{~cm}$ in diameter and very thick walls $(1.3 \mathrm{~cm})$, and, most commonly, jars with exterior-thickened (or bolstered) rims (diameters between 18 and $30 \mathrm{~cm}$ ), thick walls $(1.2 \mathrm{~cm})$, tall slightly flared necks (4.5$5.3 \mathrm{~cm}$ ), globular bodies, and flat bases. Due to the presence of a very thick rim, $26 \mathrm{~cm}$ in diameter, with quartzite temper, and deeply burnt interior, we speculate that there must have been some censers also.

Canhel Unslipped is a type of high frequency in PNT-017 at Tikal, during the Early Eb phase ([65]: E-16; [66]: Figure 119 d-e; [109]: 68; [67]). However, it is not reported from other sites in central Peten. It is a rare type at Cahal Pech, probably imported from central Peten ([61]: 626). The Early Jenny Creek phase at Barton Ramie, Belize, included similar forms to Canhel ([103]: Figures 15a, f, 20e, 21d; [63]). The large jars with tall necks of Canhel Unslipped, although not identified, may be present at Seibal and Altar de Sacrificios among the Achiotes Unslipped jars with similar forms ([112]: Figure 33a-g; [46]: Figure 1c; [67]), underscoring the difficulty of separating body sherds of the pre-Mamom Canhel type from the Mamom Achiotes type [67]. The dominant unslipped type of the Cunil phase at Cahal Pech is Sikiya Unslipped, which has a coarse paste, burnished surfaces, highly variable colors, extensive fire clouding, and dominant jar forms with short outcurved necks and direct rims ([64]: 165). Clark and Cheetham point to these differences in the pre-Mamom horizon jar forms of the Belize Valley vis-àvis those of the central Peten, suggesting that they may be explained by tribal differences between the Maya inhabitants of the two regions [7].

Buenavista-Nuevo San José does not have all the forms found at Tikal in the type Canhel Unslipped or in Achiotes Unslipped, probably because our sample is limited. Nevertheless, the Buenavista forms are close to Tikal. Although Cheetham [67] believes that Canhel is the precursor of Achiotes, the paste, forms, and surface finish of the Buenavista-Nuevo San José Canhel sherds are distinct, as the Canhel jars are of coarse paste, with bolstered rims and tall necks, while the Achiotes jars are of medium pastes, with direct rims and short outcurved necks. Nevertheless, we do see similarities between the whole unslipped assemblage at Buenavista and the subsequent Achiotes group.

The second most frequent unslipped pottery belongs to the Calam (Buff) group (Figure 13) which was also established at Tikal by Culbert $[65,66]$. Like Canhel, the paste of the Calam vessels includes coarse crystallized calcite mixed with thick fragments of opaque calcite. It is a compact paste of a yellowish-buff color (7.5 YR 6/6, 10 YR 5/3, 6/3, 6/6). The majority of the sherds lack a dark core. Some examples present firing clouds on the exterior. The few partial vessels that we have found also show clouding on bases and exterior walls. The surface finish of these vessels corresponds to a type of self-slipping (from burnishing and/or polishing) or, less likely, an eroded buff slip (7.5 YR 6/6, 10 YR 5/3, 6/3,
6/6), similar to the color of the paste. One example had a type of grooved everted lip (or hooked rim) as well as a circumferential groove on the exterior below the rim (Figure 13(a)).

By far the most common Calam Buff form present at Buenavista-Nuevo San José is a bowl or dish with bolstered or slightly outcurved rim, thick flared walls, and thick flat bases. Two bowls (Cat. 200,937 A and B) recovered in the deepest fill in units excavated behind Str. 7 had diameters of 19 and $34 \mathrm{~cm}$, heights of 4.4 and $5.5 \mathrm{~cm}$, and walls between 0.8 and $1 \mathrm{~cm}$ in thickness. These Calam Buff vessels were found together with a fragment of a Chi incised plate or dish (described above, Figure 11), and this context may represent a dedicatory cache associated with the earlier version of Str. 7. A third bowl was quite large: it measured $43 \mathrm{~cm}$ in diameter, $5.5 \mathrm{~cm}$ in height, and $1.2 \mathrm{~cm}$ in thickness. It had a slightly flaring rim with labial grooving. All these are open forms, generally considered to be used to serve food. Their forms are similar to those found in the slipped types, except that these are larger and thicker. Such large platters could have been used to serve large quantities of food, or, in other words, for feasting.

Apparently Calam Buff is a local type of medium frequency at Tikal in the Early Eb phase where there are a variety of forms ([65]: E-17; [66]: Figure 117a-d; [109]: 55, Figure 29 , Figure 30, 68; [67]). The bowl form found at BuenavistaNuevo San José is similar to the one identified in the Eb-phase problematic deposits ([66]: Figure 117a-d; [109]: Figures 2930). Rice notes that they only found one Calam Buff sherd at Nixtun-Ch'ich' in the unit N1100/E200, Level 12, near Str. 183 ([69]: 266). However, Cheetham ([67]: 147) believes that examples of this type, although not formally identified, are placed by their excavators in other wares and groups and are probably present at Uaxactun, Ixtinto, and various other sites in the Yaxha-Sacnab Lakes ([68]: 17, Figure 5j; [69]: 266, 273, Figure 146t-v).

A possible equivalent from the Tayasal-Paxcaman Peninsula in the Central Peten Lakes region is the Mamom horizon Temchay ceramic group which is defined by A. Chase as a "burnished buffware of tecomate variant form" ([113]: 29). It is possible that Calam Buff appears as far east as Barton Ramie under Jocote Orange-Brown: Ambergris Variety ([103]: 67, Figure 20a), although this variety is dated to the Early Jenney Creek (Early Mamom) phase. However, the Calam Buff type is absent from the rest of the Belize River Valley or from the Pasion region. This contrasts with how frequent Calam is at Buenavista-Nuevo San José and at Tikal. If indeed the function of these large platters was for feasting, it suggests that this activity was frequent at Buenavista in pre-Mamom times. It is surprising that although this tradition continues into Early Mamom, it then disappears [67].

Calam Buff's cream surface may connect it with the white-washed Huetche White of the Pasion region, a possibility broadly suggested by Inomata et al. [43]. However, our observations of Tikal's Proyecto Nacional Tikal Eb collections show that Calam Buff (both at Tikal and at Buenavista-Nuevo San José) generally fits better with the unslipped pottery, with its medium paste, and thick-walled and large vessel forms. 


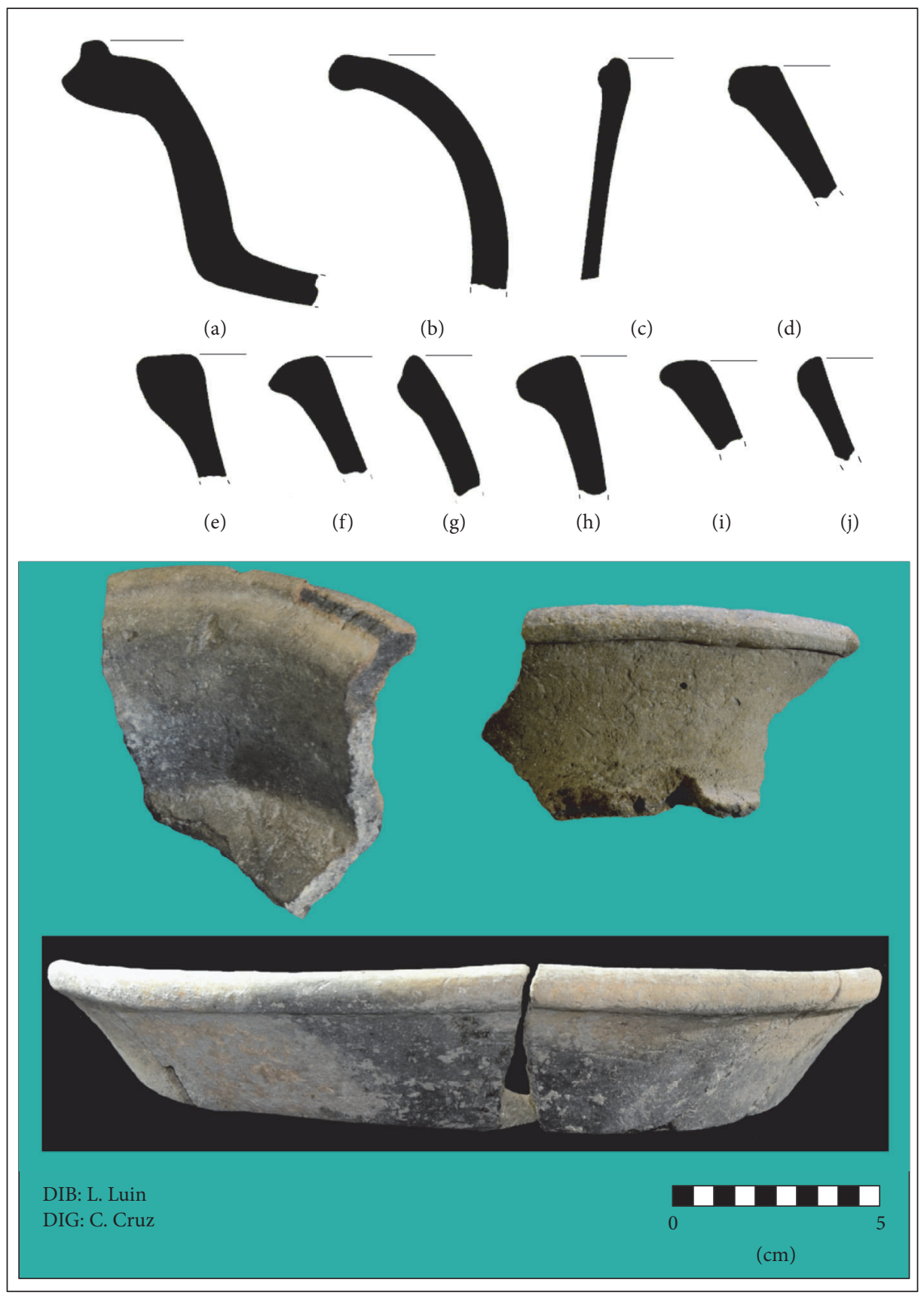

FIgURE 13: Calam Buff.

The third group among the unslipped pottery, Cabcoh (Striated), is less common than the two just described (Figure 14). However, we are unsure that we could distinguish between Cabcoh and the subsequent Zapote Striated, so the frequency of this type may be higher than we think. Cabcoh Striated was first described by Culbert at Tikal $[65,66]$.

The paste is similar to that of Canhel Unslipped, with crystallized calcite, from coarse to medium in size, of a light pinkish-brown color (7.5 YR 6/6 y 7/4, 10 YR 6/3), as well as black and red ferruginous inclusions. Both grayish dark cores and fire clouding appear on the interior and exterior of sherds and vessels. As the name indicates, these vessels are striated, generally on the neck. One example was decorated with light diagonal striations, which seem to be the marks of the smoothing instrument, along the exterior between the rim and neck. Two jars had horizontal light striations inside the rim just before the inflection of the curved neck. Another example of this type had a blackened circumferential band from the lip down half of the neck inside and out, with asymmetrical striations only on part of the interior of the neck. Additionally, some unslipped jar necks and closed bodies also display very fine striations, asymmetrically placed on their 


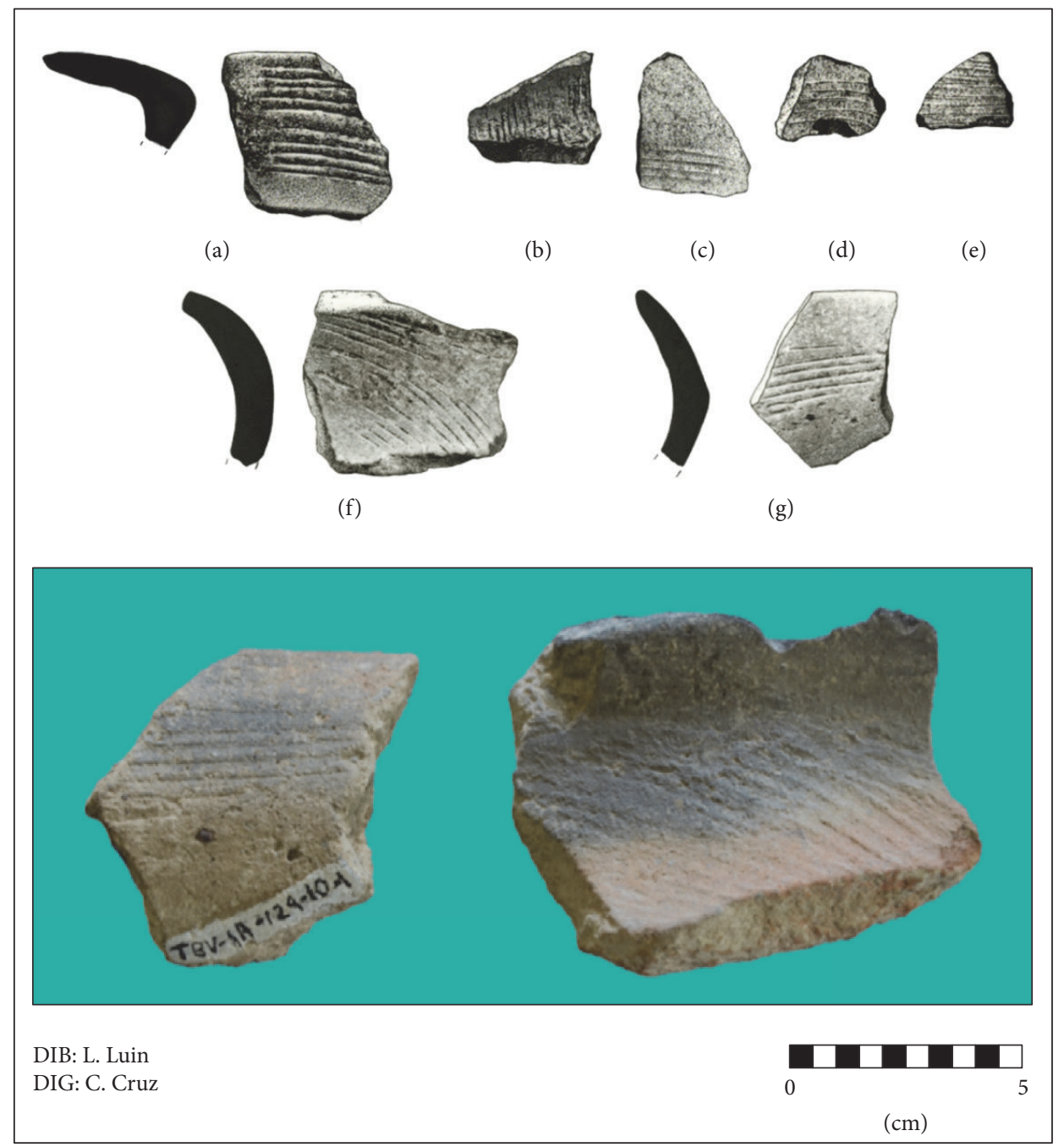

Figure 14: Cabcoh Striated.

exterior. There is an only form, jars. Three thick rims (0.9$1.4 \mathrm{~cm}$ ) in the Buenavista-Nuevo San José collection probably belonged to jars with slight flaring to everted rims, and short necks without a well-defined collar. These rims range between 16 and $20 \mathrm{~cm}$ in diameter.

This type is found in Tikal where it has a high frequency, and it is placed at the transition between the Eb and Tzec Mamom complexes ([65]: E-16; [66]: 5; [109]: 54-55; [67]). Culbert writes that it is possibly present at Uaxactun, during the Mamom phase, although it is not formally identified. Rice describes similar jars with lightly striated necks from the lowest level (Level 12) in a pit behind Str. 183 at NixtunCh'ich', but she places them in Achiotes Unslipped ([69]: 266). Because of its association with other types of the preMamom horizon and its architectural context, we prefer placing the examples from Buenavista-Nuevo San José in the Eb ceramic sphere. No striated pottery was identified in other sites of central Peten, in the Belize River Valley, or in the Pasion region, so it appears to be a local tradition of the $\mathrm{Eb}$ sphere.
A fourth group of unslipped pottery was easily distinguishable from the other ceramic groups based on its unslipped to self-slipped, smoothed red surface, and thin walls, which we called Unnamed Unslipped Thin Red Paste (Figure 15). Although previously identified as Kolok Red (a type defined by Rice [68] in the Lakes Yaxha-Sacnab region), further discussion distinguishes the Buenavista material which is unslipped to self-slipped, while Kolok Red has a dull eroded red slip. The paste and forms of this Unnamed Unslipped Thin Red Paste are different from Canhel Unslipped and Achiotes Unslipped. Although Cheetham ([67]: 147) has placed the Kolok Red type as Uck Red in his reexamination of the Yaxha-Sacnab pottery, a coarse paste distinguishes this material at Buenavista from Uck Red which has finer pastes.

The coarse paste of this ceramic group includes granular calcite, but the temper appears to be most frequently fine sand or quartz. The paste color is in the orange-red range (2.5 YR 4/2, 4/6, 5/4; 5 YR 5/4 5/6; 7.5 YR 5/6, 6/4), and sherds are usually well fired, without a dark core. Surfaces are coarse, of the same color as the paste, having received only a poor 


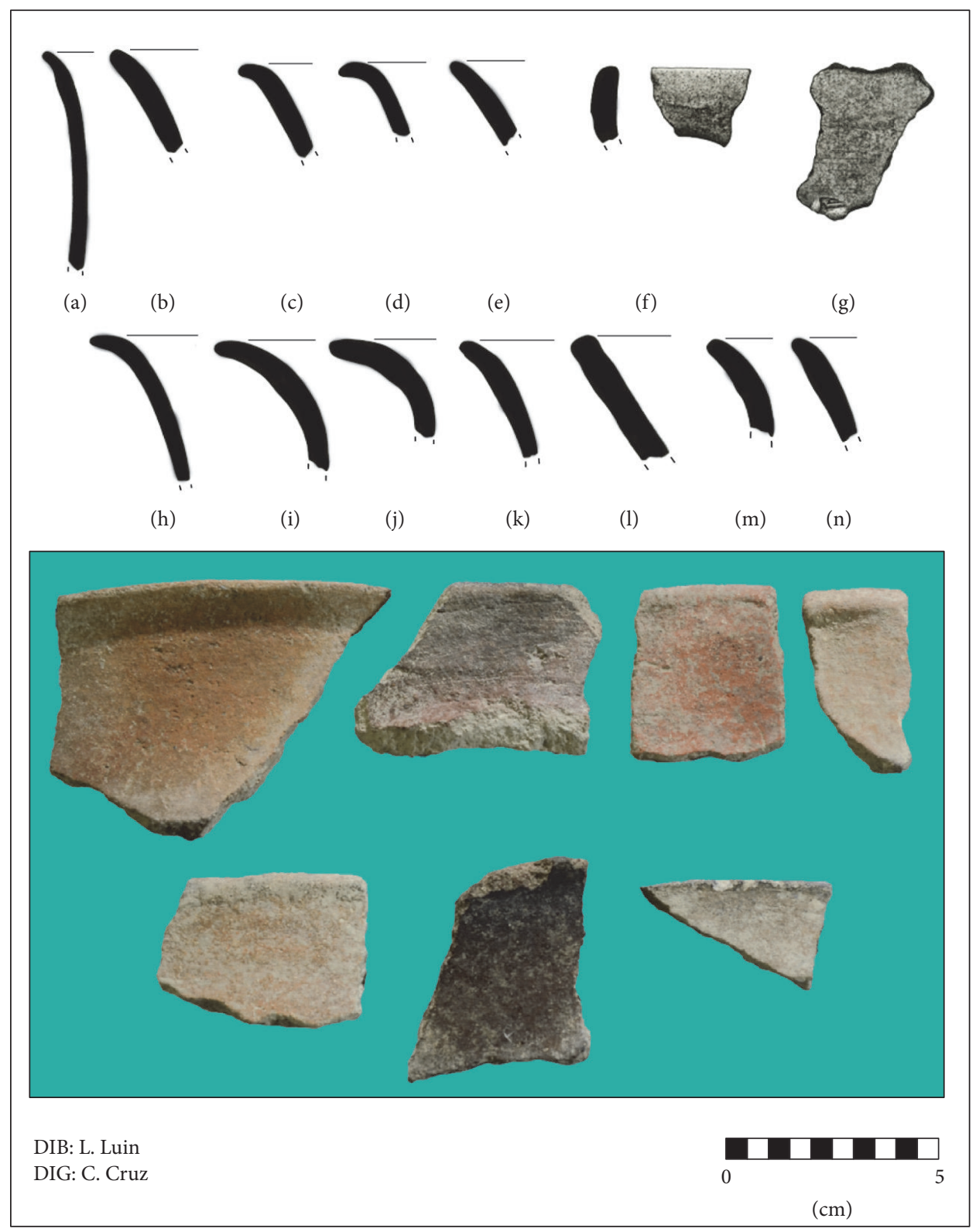

FIGURE 15: Examples of the Unslipped Thin Red Paste (originally called Kolok Red).

smoothing, with the paste revealed in some spots. However, in some cases, there may be a reddish wash or possibly selfslip. One sherd had nail impressions on its exterior, possibly pertaining to a mushroom stand. The predominant form is a jar with direct rim, diameter varying between 13 and $18 \mathrm{~cm}$, and slightly outcurved neck (more rarely, tall flared necks). The collar or the joint between the neck and body is almost unnoticeable in some cases. The jar body was globular, but of small dimensions because the sherds are relatively thin (6$8 \mathrm{~mm}$ ) in comparison with the other unslipped types. It is possible that some had flat thin handles, as we found one example of such a handle.

These could be similar to unslipped types found in the Belize Valley as, among these, reddish pastes predominate, but for now we have left this group unnamed, as this may be a very local type.

A final group of unslipped pottery has been left as Unslipped Impressed although it may be the type Baldizon Impressed from the Pasion region, or its equivalent produced in central Peten. It is very rare at Buenavista-Nuevo San José (Figure 16). In contrast to the other unslipped pottery, this paste is finely granulated, with small calcite inclusions, and varies in color between yellowish-brown and reddish-brown (2.5 YR 5/4, 5/6, 10 YR 6/3). Additional inclusions are red and black ferruginous. Underfiring and uneven firing are attested by dark cores and fire clouding on the exterior walls. The unslipped surfaces were decorated with nail or finger impressions. Two examples had double rows of nail 


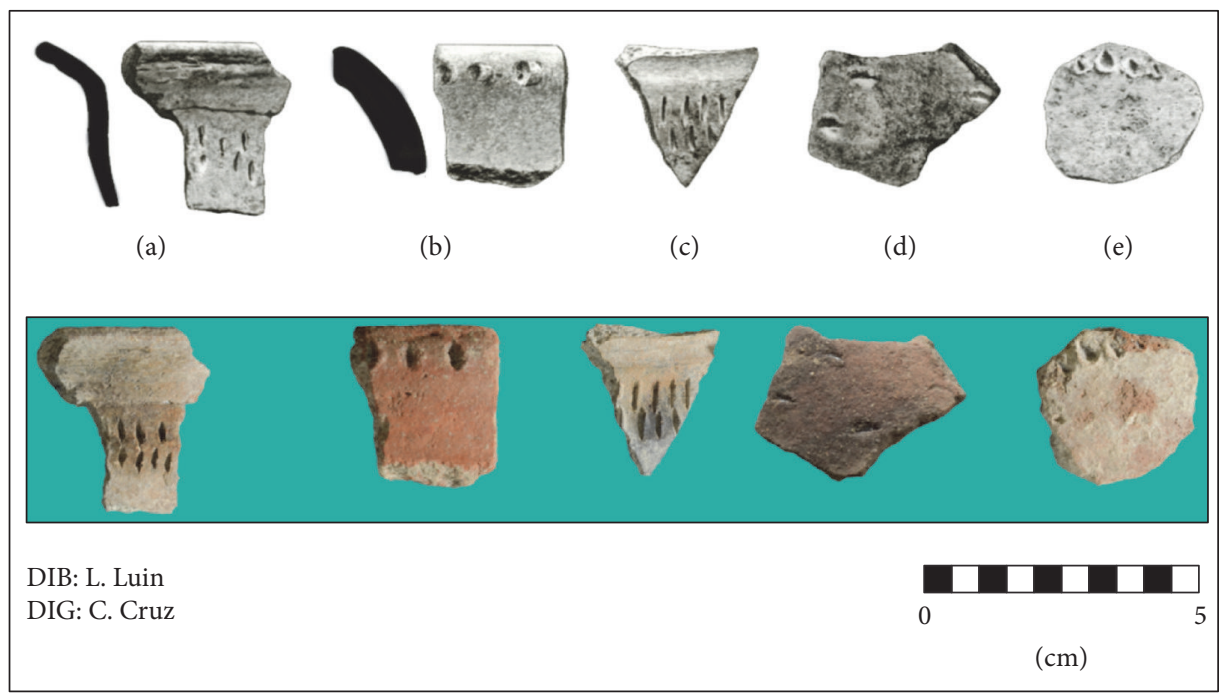

FIGURE 16: Unnamed Unslipped Impressed.

impressions, while a rim and two body sherds had digital impressions. None of these impressions were on fillets. The sample is very small, with few rims, but there must have been small bowls as well as small jars since we recovered a collar and several body sherds from jar forms.

In Tikal, there are a few such examples, but they are included in Canhel with nail impressions ([109]: Figure 30). Cheetham [67] also observed 5 sherds in Tikal's PD 6 y 12, which were similar to Baldizon Impressed, and he dates these sherds to Late Eb and Early Tzec Mamom. The majority of the examples from Buenavista-Nuevo San José are comparable to Baldizon [Punctated] Impressed of the Xe phase at Altar de Sacrificios ([46]: Figure $1 \mathrm{~m}$ and 2a, n), and to the same type of the Real phase at Seibal ([56]: Figures 27-30), although, at the latter site, the impressions occur on small fillets more often than directly on the vessel body. The similarity between such early impressed vessels and the Pasion type has also been noted by Rice at sites in the Yaxha-Sacnab basin and at Ixlu in the Ah Pam phase ([68]: 21, Figure 5e; [69]: 273, 284, Figure 1451), where the examples illustrated by Rice are close to our potsherds. Baldizon Impressed was also identified in low frequency in Southeast Peten, although it is placed in the Resumidero phase of the Late Mamom to Early Chicanel ([114]: 48, Table 4). Finally, Inomata et al. see the appearance of such impressed pottery as characteristic of the Real 3 subphase at Seibal ([43]: S1, p.2).

5.3. Slipped Pottery. Among the most distinct of the six groups of slipped pottery is the Ainil (Orange) pottery (Figures 17, 18, 19, and 20). This group was first defined by Culbert $[65,66]$ at Tikal. At Buenavista-Nuevo San José, the paste of Ainil Orange is fine, hard, and compact, with rare calcite inclusions, and a color that varies from yellowish-red to grayish-brown to yellowish-brown (7.5 YR 5/4, 5/6 6/6, 7/6; 10 YR $5 / 2,5 / 4,6 / 4$ ). Occasionally, there is a small quantity of volcanic ash and red or black inclusions. The majority of sherds are well fired (with a clear clinkiness), generally lacking dark cores; in the few cases where a dark core is present, it is very thin. The majority of these sherds present a hard matte or dull slip, generally yellowish-orange to yellowish-red to buff (10 YR 5/4, 6/6; 7.5 YR 4/4, 5/6, 6/6, $6 / 8$ ), present on both sides of the sherds. The slip is variegated, mottled, and with frequent fireclouding. A few examples have polished slips, almost lustrous, like Classic period pottery. The variegation sometimes appeared to be the result of experiments in resistance. In these cases, it is possible that the color variegation was created using a cream slip stained with orange or yellow. On a few sherds, the slip is much more reddish on both interior and exterior surfaces, again possibly due to experiments involving differential firing or resist. The principal decoration consists of one or two circumferential postfire grooves on the rim or close to the rim on the exterior of the vessels (type Xpokol incised). There were also some examples with horizontal circumferential shallow fluting (type Xtoyil Fluted). Even rarer is chamfering, one case with digital impressions, and one example with excised lines.

The majority of rims represent small plates or dishes with direct, squared, or slightly outcurved rims, with diameters between 14 and $20 \mathrm{~cm}$. The walls are very low $(2.5-4 \mathrm{~cm})$ and almost vertical in the case of plates and incurved in the case of bowls. These are thin walled vessels $(7-8 \mathrm{~mm})$. Plates have flat bases and bowls have rounded bases. There is an exceptional example of a plate with higher walls $(5.5 \mathrm{~cm})$. The dimensions of these plates and bowls are smaller than similar forms of the Mamom and Chicanel horizons. There were also rare rims of tecomates, with direct rims and diameters between 5 and $8 \mathrm{~cm}$, and strongly incurved walls. In addition, the presence of jars is also suggested by a few necks and closed body sherds.

Ainil Orange is a minor type in Tikal, rare in the $\mathrm{Eb}$ phase, and more frequent in early Tzec Mamom ([65]: E22E23; [66]: 5; [63]). Cheetham estimates that Ainil Orange is less than $1 \%$ of the Eb ceramics at Tikal ([4]:30). Its higher presence at Buenavista-Nuevo San José (10.8\%) together with the presence of grooving, fluting, and chamfering suggests that the site was mostly intensively occupied during the latter 


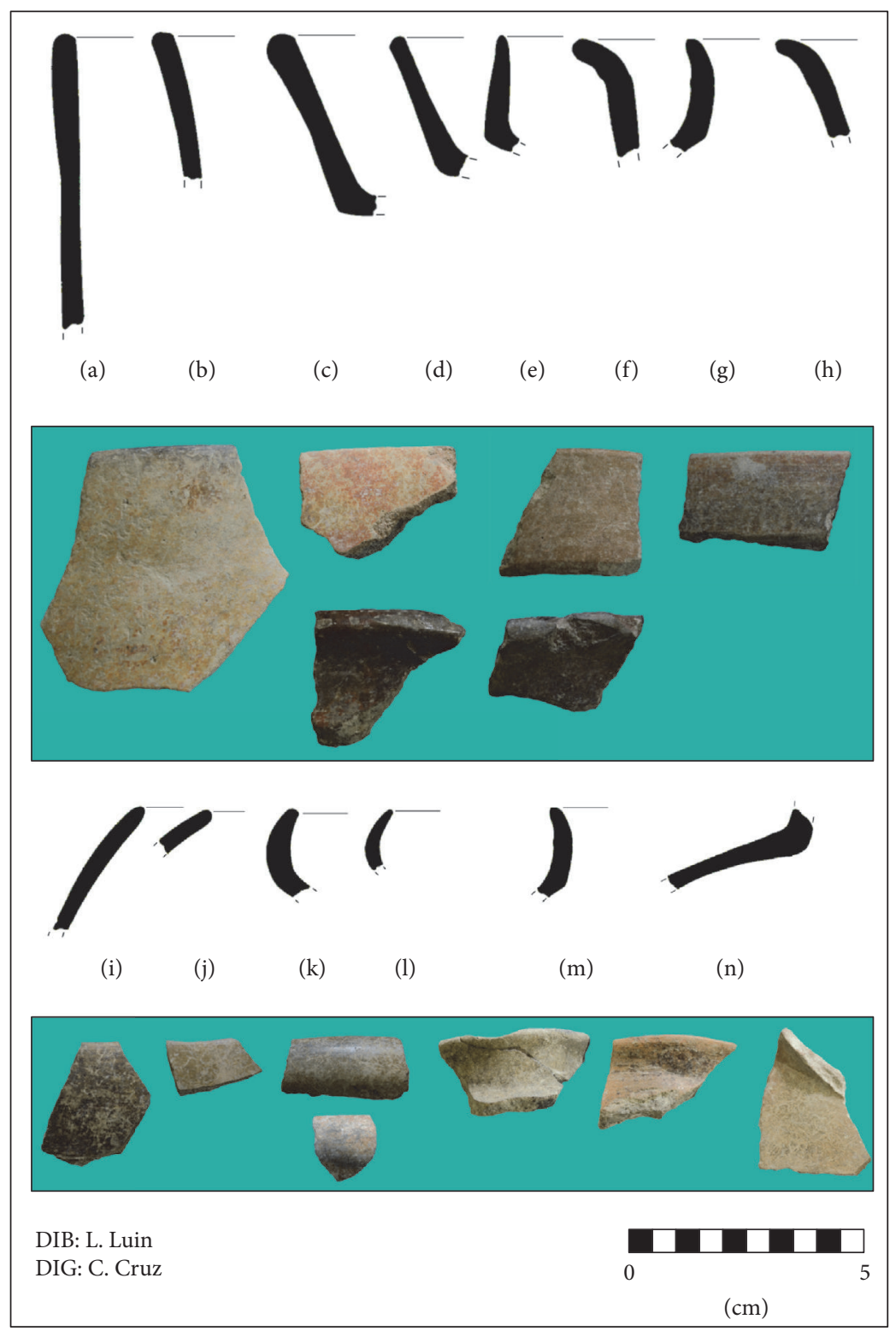

FIGURE 17: Ainil Orange.

half of the pre-Mamom time period, perhaps close to 800700 BC Our examples with their fine paste are closest to the Fine-Inclusions Variety of Ainil Orange at Tikal ([65]: 23). Cheetham suspects that this type is characteristic of central Peten, with no parallel in the Belize Valley ([67]: 60-62). Orange slipped pottery is found at Cahal Pech in larger proportions than at Tikal, but as the type $\mathrm{Cu}$ Orange, a precursor to Mars Orange [4, 61]. Cheetham places the frequency of this type at Cahal Pech at 3\% ([4]: 30, Table 3.2). Rice mentions one Xtoyil Fluted sherd at Ixlu ([69]: 282, Figure 146r), where it must have been a rare type as it is not mentioned in the general descriptions. In contrast to the situation at Tikal and Ixlu, the Ainil ceramic group is the second most common in the pre-Mamom-to-Early Mamom Nix complex at Nixtun-Ch'ich', a site also on Lake Peten Itza ([39]: 408). Although Ainil is not present in the Pasion region, the tradition of orange slipped pottery is frequent at Altar de Sacrificios as Yaltata Orange in the Xe phase (9\% of the whole Xe complex) [4]. Both Ainil Orange and Xpokol Incised have been identified in Southeast Peten, but they are placed in the Resumidero complex of Late Mamom to Early Chicanel times ([114]: 48, Cuadro 4). Although Ainil Orange is not present at Cuello during the Swasey phase, an orange-slip tradition, the Chicago group (29\% of the Swasey complex), is strong there $[50,55]$.

Another slipped group is Boolay (Brown) although it is not common at Buenavista-Nuevo San José (Figure 21). Established at Tikal by Culbert $[65,66]$, this group is often placed in the Mamom sphere, but we follow Cheetham et al's classification in which Boolay pertains to the Eb phase of the Cunil horizon [61]. Similar to Ainil Orange, the paste is fine, hard, and compact with few inclusions. The paste color 


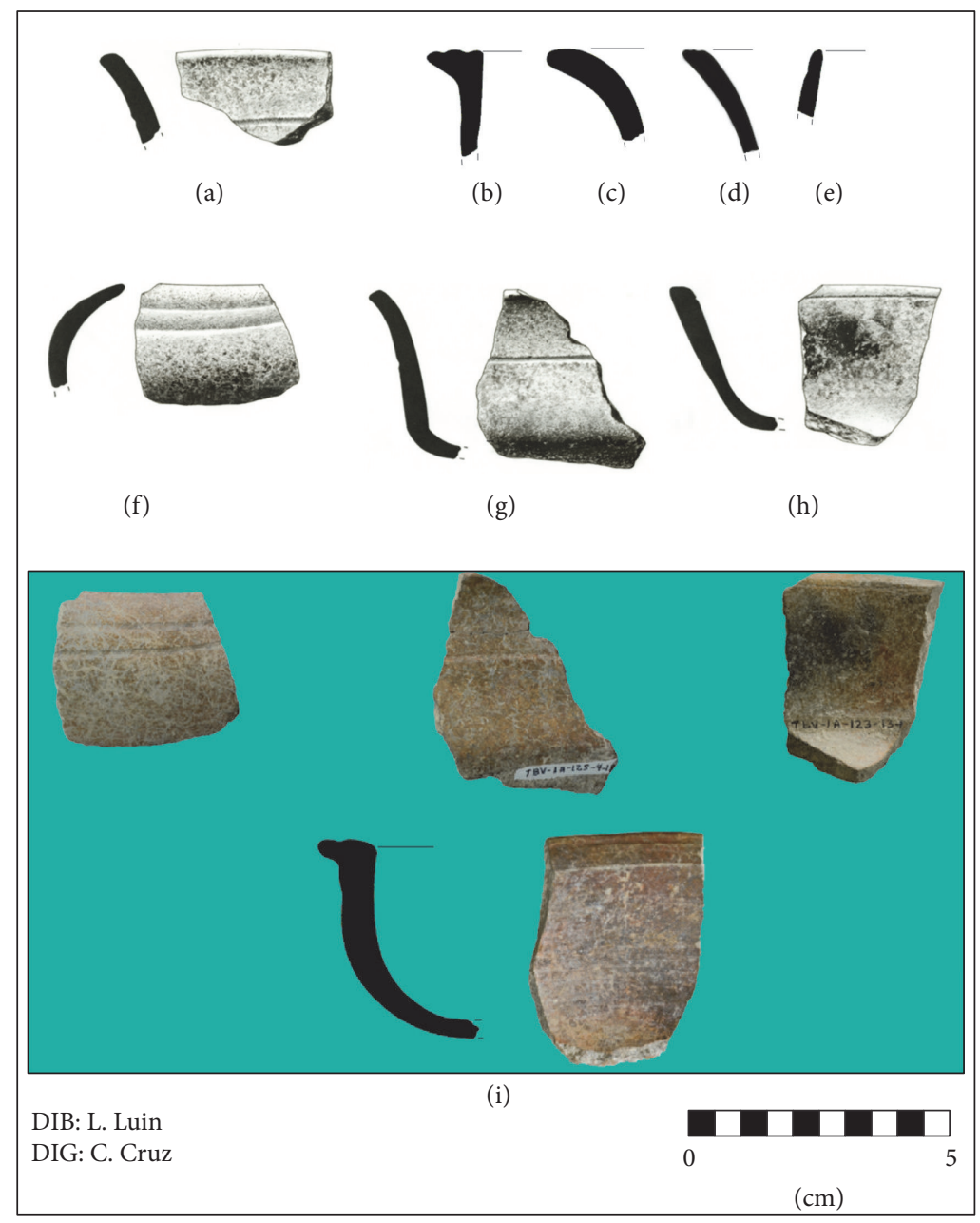

FIgURE 18: Xpokol Incised in the Ainil ceramic group.

varies from brown to yellowish-brown (7.5 YR 5/4, 5/6 6/6, 7/6; 10 YR 6/3 6/4, 6/5). There are few examples with black cores. The mottled-variegated brown slip is generally reddishbrown (5 YR 3/3, 3/4 4/4, 4/6, 5/6, 5/8) and covers all parts of the vessels, including bases. Some examples present fire clouding. These sherds are placed in this type because they are distinct from the black-to-brown slipped materials (Chi ceramic group) and from the dark red or mottled red vessels (Uck ceramic group). It is worth noting though, as other scholars have done, that this type grades into the reds, mottled oranges, and black-brown. For these reasons, it is hard to say if the brown slip color was intentional or a mistake in firing. The sample from Buenavista-Nuevo San José is extremely small, and we provisionally place it in this group. Decoration consisted as in Ainil Orange only of simple, single, or multiple circumferential incised lines (Bechh Incised) mostly preslip. On one rim and on some bodies the incisions range into grooving. Only one form dominates at Buenavista-Nuevo San José: a bowl with direct or exterior-thickened rim, with diameters between 18 and $23 \mathrm{~cm}$, and slightly to strongly incurved sides. Bases may have been flat.

This is a minor group at Tikal ([109]: 63, 68; [65]: E23-25; [66]: 5). Cheetham lists brown slipped pottery as reaching $6 \%$ of the Eb complex [4]. Although not formally recognized by the original excavators, Cheetham has identified this type at Uaxactun and Seibal [67]. It is also found in the Central Peten Lakes region mostly as the incised and grooved decorated types ([69]: 262-263, Figure 138i-m, 278-279, Figure 144ae). Rice explains the difficulty of classifying material into this type [69]. She follows Chase who first defined the Vecanxan group in the Chunzalam Mamom complex of the Tayasal peninsula as a variegated cream-slipped type but whose slip ranges from black to red, gray, brown, and cream $[113,115]$. In her analysis of the Nixtun-ch'ich' and Ixlu pottery, she preferred to put the sherds with reddish-brown or blackbrown slips into Boolay, brown-gray into Vecanxan, and light brown into Baadz. We did not make such fine divisions, as our sample was too small and slip color varied among these colors on the same sherds. Apparently the Boolay group permeates Early Mamom at Topoxte, where the group is a major one, but problematically placed in the Flores Waxy ware ([116]: 166). The type is also identified in Southeast Peten, but, as in Topoxte, it pertains to the Mamom horizon and even early Chicanel horizon ([114]: 48, Cuadro 4). The BuenavistaNuevo San José material is not waxy (as Flores Waxy ware), but rather dull, matte, and sometimes polished to low luster. 


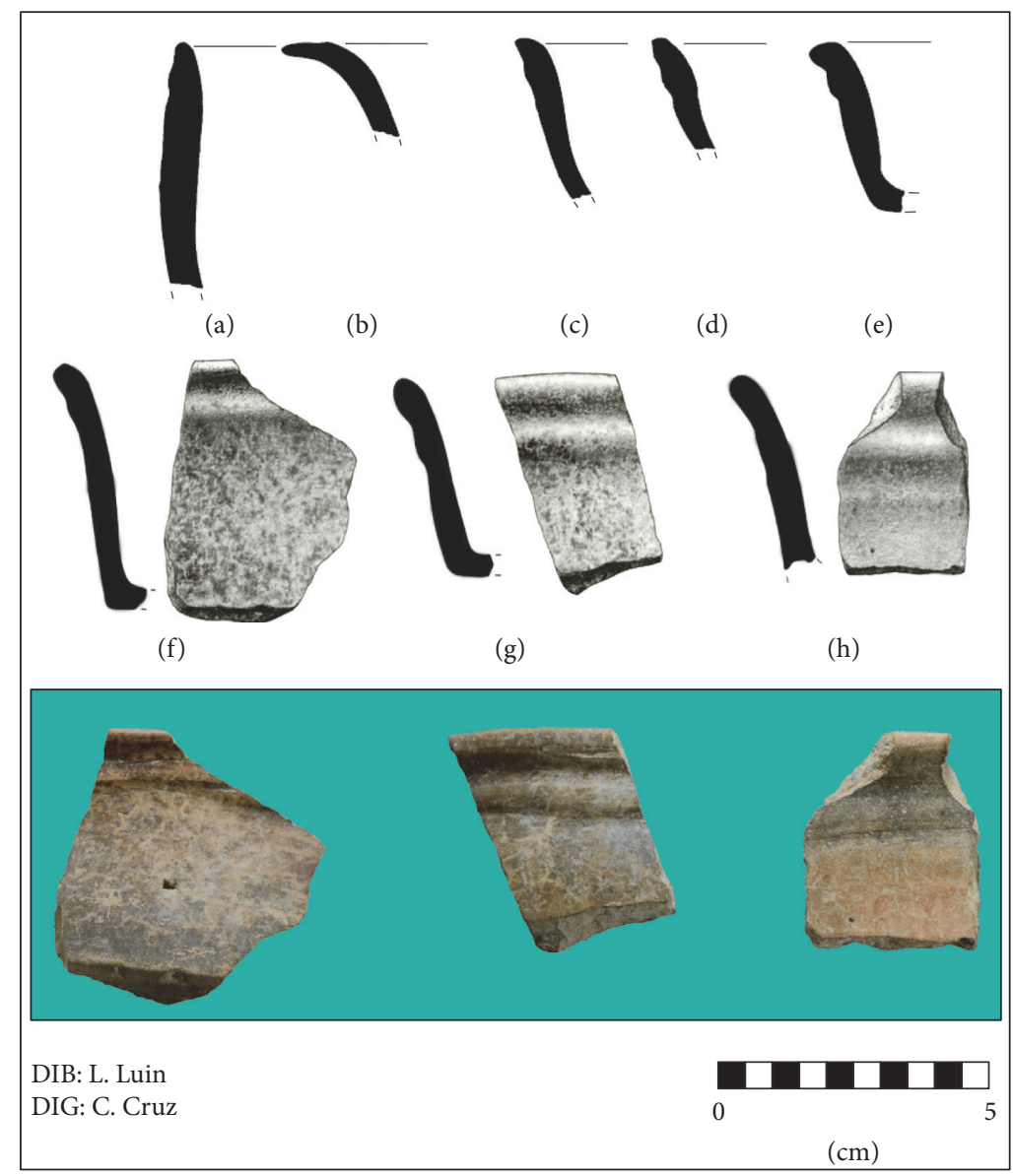

FIgUre 19: Xtoyil Fluted in the Ainil ceramic group.

Boolay Brown is absent from the Cunil complex at Cahal Pech [61]. However, Cheetham [4] identifies brown slipped pottery as a rare tradition in Cunil, with frequencies less than $1 \%$, but he does not identify the types. Sullivan et al. do not describe a formal group of brown slipped pottery in the Cunil complex at Cahal Pech but mention that the Cocoyol Cream-slipped group includes slips that vary to pale brown ([64]: 164).

The second most common group among the slipped pottery at Buenavista-Nuevo San José is the Uck (Red) group (Figures 22-29), originally defined at Cahal Pech by Awe and Cheetham $[59,61]$. Similarly to Ainil and Boolay, the paste is fine with small to medium calcite inclusions, as well as volcanic ash which, when present, gives the slips a darker red color. The paste varies from dark brown to gray (2.5 YR 4/0, 4/6, 7.5 YR 4/6, 5/6, 6/4; 5 YR 5/6, 10 YR 6/2, 6/6), with black and red ferruginous inclusions, and in some cases mica. The paste is hard, probably fired at a high temperature. Generally, there is no dark core, but those examples, which have volcanic ash temper, tend to have dark thick cores. The presence of volcanic ash is similar to the Cunil material at Cahal Pech, but the more common fine calcite inclusions connect the material with the Eb complex at Tikal.

The majority of the sherds present just a low luster to matte red slip (2.5 YR 4/6, 10 YR 4/4), on both sides. In some cases, there is a gray background to the red slip, which may be due to the presence of volcanic ash, or some type of fire clouding which gives these a darker red color than most examples. Some sherds have on one side a red slip variegated with black. There are also brilliant red slips, possibly because of the presence of a cream or white underslip or underwash. It is noteworthy that the Cunil ceramics from Cahal Pech also tend to have a pseudobichrome effect as the majority of the monochrome vessels have unslipped exteriors ([7]: 322).

A good number of vessels (Kitam Incised) were incised with fine lines, postslip, and postfire, present on the rim or on the exterior of the body. Most of these were too fragmentary to identify the incised motifs. Among the identifiable designs, appear an inverted crosshatched triangle (Figure 26(e)); two partial avian serpent motifs (Figures 26(a) and 26(f)); and spirals and crisscrossing interlaced "threads" incised on the interior and exterior of the same vessel (Figure 26(g)). The avian serpent motif is identified by Cheetham $[4,60,67]$ and Garber and Awe [6] as part of a pan-Mesoamerican terminal Early Formative symbolic complex (see discussion below).

A form diagnostic of the pre-Mamom horizon, although rare at Buenavista-Nuevo San José, is a plate with a wide, completely everted rim on which two circumferential lines were incised after firing (Figures 23(c) and 26(b)); these examples from Buenavista are very similar to examples from Tikal and Cahal Pech (see discussion of this form in the Cunil 


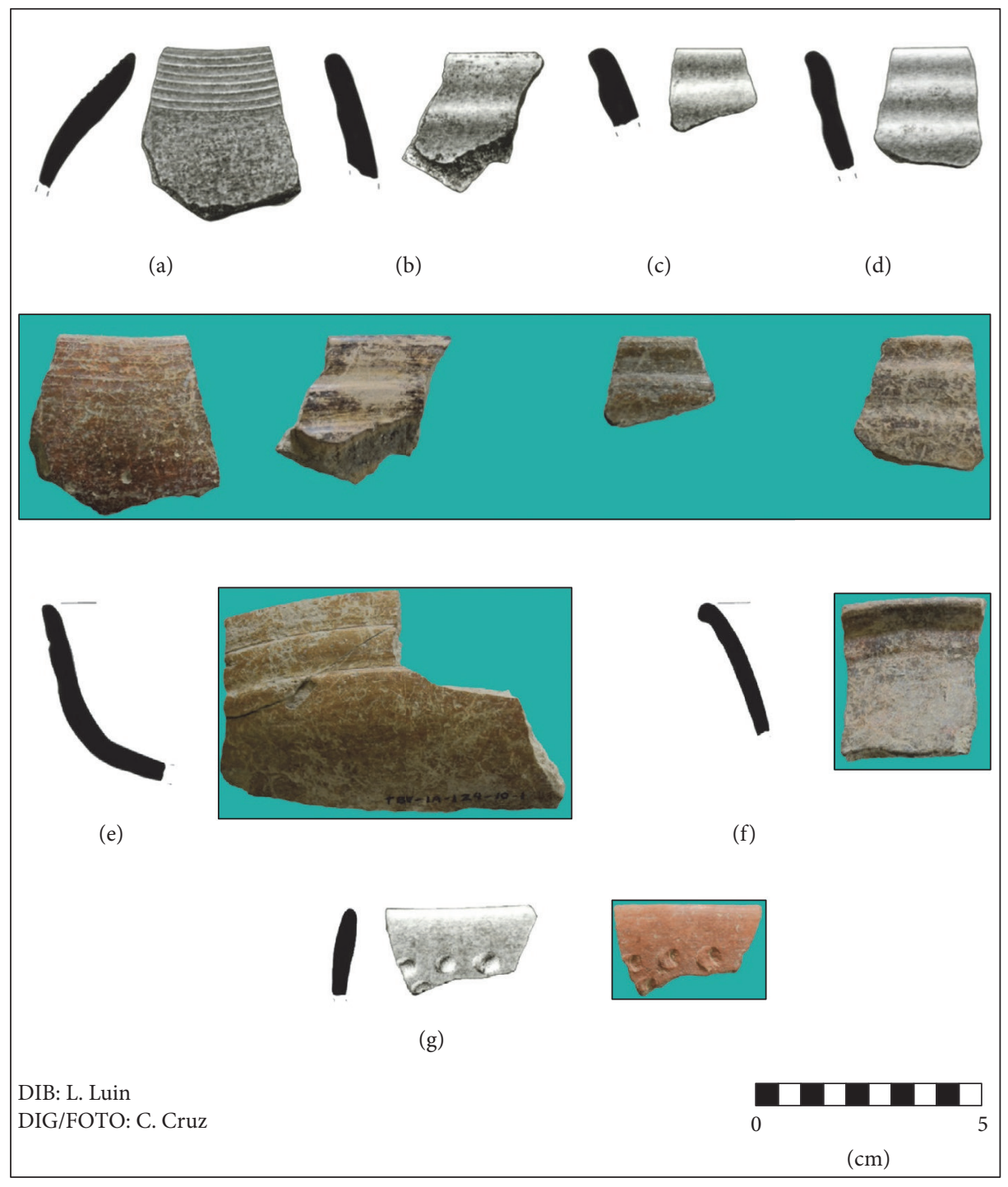

FIgURE 20: Other more rare types of the Ainil (Orange) group.

horizon as defined by Cheetham [4]). Similar examples also appear in the black slipped (Figure 31(e)) and cream-slipped (Figure 32(d)) groups. The form of these widely everted rims recovered at Buenavista are closer to the shapes found in the Real and Eb complexes, rather than the Cunil examples: the Buenavista examples have an angled juncture between rim and wall in lieu of a sharp one seen at Cahal Pech, and they are generally decorated with circumferential grooving rather than more complex designs as seen at Cahal Pech [43]. For Cheetham, this form is characteristic of the whole Cunil time period [4].

Two examples of Kitam Incised (Figures 26(a) and 26(g)) show a similar pattern of a row of short vertical incised lines along the rim or on the exterior at the junction with the base. However, the majority of the sample had one or two circumferential lines of a thick incision or groove $(4-6 \mathrm{~mm})$ made after fire, near the rim (similar to the type Pico de Oro Incised from Real and Xe complexes at Seibal and Altar de Sacrificios, resp.) (Figure 27). There were also several rims with horizontal circumferential light fluting, similar to the type Setok Fluted from the Pasion region (Figures 28(a)28(i)). Two other examples had digital impressions on the unslipped exterior and red slip on the interior (possibly Cob Red-Impressed) (Figures 28(j) and 28(k)).

Finally, a fragment of a mushroom stand was identified by the fine and dense nail (fish-scale) impressions on its unslipped superior side, although the body section had residues of red slip (similar to examples of Cob RedImpressed from Tikal). It is worth mentioning that mushroom stands appear in other sites close to 700 b.c., although they are not produced throughout the Mamom horizon, and only reappear in Chicanel times. Its presence at BuenavistaNuevo San José suggests that this form was more popular during pre-Mamom to Mamom times than previously believed, as they are found in both the Eb complex at Tikal and in Cunil assemblage at Cahal Pech [4].

Sherds from indeterminate miniature vessels with modeled decoration were also present. One final exceptional case 


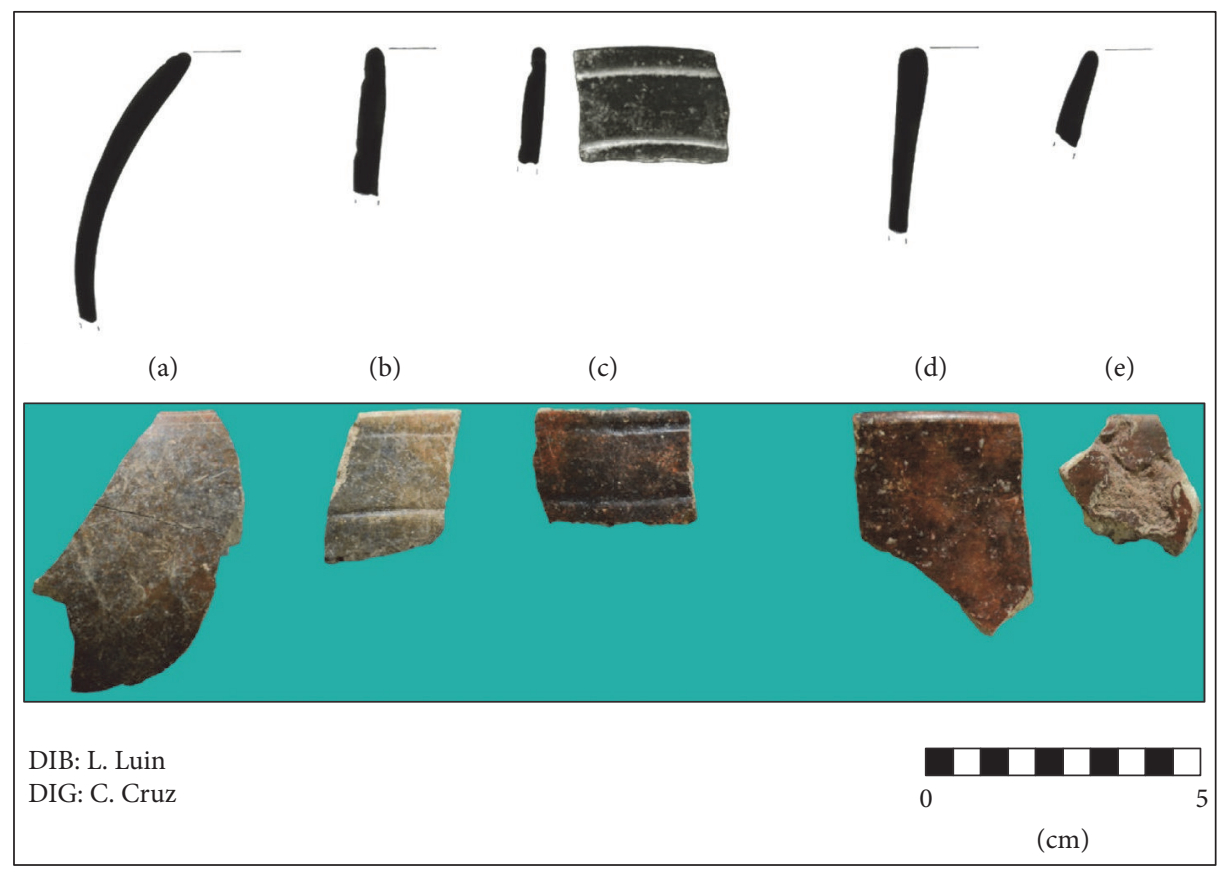

Figure 21: Examples of the Boolay (Brown) ceramic group.

(Figure 23(o)) was a red-slipped fragment with extremely thick walls of an indeterminate form, although it might be a stirrup spout, similar to one illustrated by Garber et al. from the Kanocha Cunil phase at Blackman Eddy ([62]: 36, Figure 3.5a).

A few exceptional and rare sherds (maybe imports) present cream slip on the rim and red slip on the body where zones of vertically grooved designs (possibly crosshatched triangles) are placed (Figures 29(a)-29(c)). A few other sherds have red slip on the rim and cream slip on the rest of the body (Figures 29(d)-29(e)). These bichromes could be Haleb Red-on-Cream (from Tikal) or Toribio Red-on-Cream (from the Pasion region). Alternatively, they may represent the initiation of a local tradition, precursor to the type Muxanal Red-on-Cream characteristic of the Mamom horizon, but the matte slips of our sample are very different from the waxy slips of Muxanal.

The majority of the Uck (Red) sherds represent plates with a variety of lip forms: direct, beveled, square, and slightly bolstered towards the exterior. Walls are outflared, and bases are flat. One example has a wide completely everted rim, diagnostic of the early part of the Cunil phase (as discussed above). A less common form is the bowl with a similar variety of lip-rim shapes, slightly incurved walls, and bases either flat or rounded. The diameters of these plates and bowls are smaller than Mamom or Chicanel examples. They range between 14 and $26 \mathrm{~cm}$, with very low walls $(2.5-4 \mathrm{~cm})$ and are very thin (7-8 mm). A few examples showed higher walls of $5.5 \mathrm{~cm}$. Although few, there were also sherds that belonged to tecomates with direct rims, diameters between 9 and $25 \mathrm{~cm}$, and strongly incurved walls. Another rare form consists of small jars, with diameters of $8-9 \mathrm{~cm}$, and necks relatively straight ( $4.4 \mathrm{~cm}$ tall) and thicknesses of 7-8 $\mathrm{mm}$. One jar had a slightly exterior-thickened rim, and a tall neck with signs of a handle between the rim and neck.

There are a few modeled sherds for which the form could not be determined, although it is possible that they belong to censers. Finally, we have an exceptional example of a modeled fragment with matte red slip which may be a clay mask (Figure 25(b)).

According to Cheetham [61, 67], the sherds identified by Culbert as Joventud Red of the Early Eb phase excavated from the chultun under the North Acropolis and the Chultun 5G-15 are Uck Red. Tikal also has the Haleb Red-on-cream Fluted-grooved type ([65]: E27), which is similar to our examples of grooved red-and-cream bowls and dishes, but Culbert places this type in the Late Eb facet which Cheetham identifies as Early Mamom $[4,61,65,67]$. It is possible that the Uck group corresponds to the Kolok Red defined in the Ah Pam phase at Yaxha-Sacnab ([68]: 17), but there is no extensive description of this type, and it is not mentioned again in Rice's ceramic analysis of Early Ah Pam levels at Nixtunch'ich' and Ixlu [69]. Cheetham's restudy of the Yaxha-Sacnab pottery does indeed reassign Kolok Red to Uck Red [67]. Personal observation of the earliest pottery at Nixtun-Ch'ich' by Foias shows close similarities with the Buenavista preMamom pottery, with the same slip qualities and technological features (of high temperature firing). The NixtunCh'ich' assemblage differs from Buenavista in having low frequencies of the Uck Red group, in favor of cream slips (which dominate) and black slips (less common than cream slips).

The Uck Red group is very frequent in the Cunil phase at Cahal Pech, Pacbitun, and Blackman Eddy, according to 


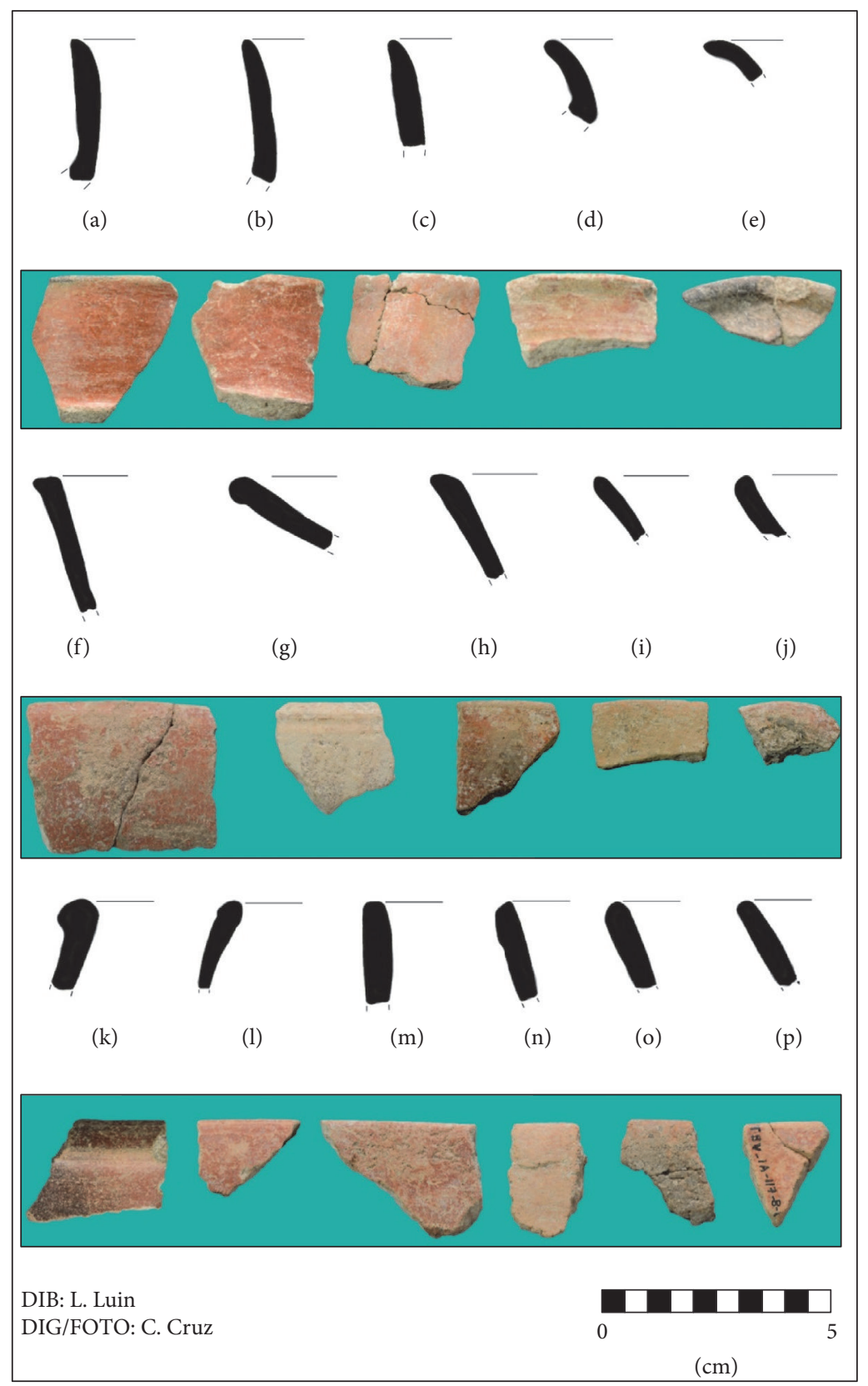

FiguRE 22: Uck Red.

Cheetham [67], where plates with wide horizontally everted rims show contemporaneity or overlap with the BuenavistaNuevo San José early pottery. Three examples of such plates from Buenavista are shown in Figures 26(b), 31(e), and 32(d). More recent presentations of the Cunil complex at Cahal Pech split the Uck Red type into two separate ones: the mottled or variegated red slips are placed into the Mo Mottled type, while only the pure red slips remain in Uck Red; Kitam Incised then becomes the incised version of Mo Mottled, while Baki Incised is the incised version of Uck Red ([64]: 164). The Buenavista-Nuevo San José examples were sometimes mottled, although variegation was more characteristic of the Ainil and Boolay groups.
The Consejo (Red) group from Swasey complex at Cuello includes lustrous, low luster slips, and occasionally waxy slips ([7]: 322), so it is distinct from Uck Red, and closer to the Mamom slips. Kosakowsky and Pring observe that the Consejo Red has a dark vermilion-red slip placed over an underslip which varied in color from pinkish, tan, and white to gray, but they still see it similar to Abelino Red from Ceibal and Altar de Sacrificios ([117]: 62-63). The Swasey complex also included vessels with red-and-cream slips, which are very close in form and color to Muxanal Red-and-Cream of Early Mamom ([117]: 323). During the subsequent Bladen phase at Cuello, Tower-Hill Red-on-Cream appears, and this tradition parallels the Buenavista red-on-cream examples. Inomata et 


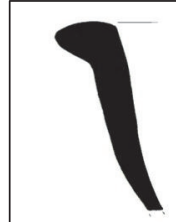

(a)

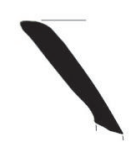

(d)

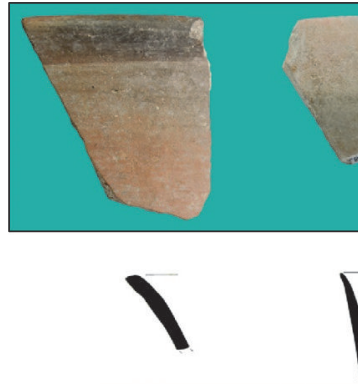

(e)

(f)

(g)

(h)
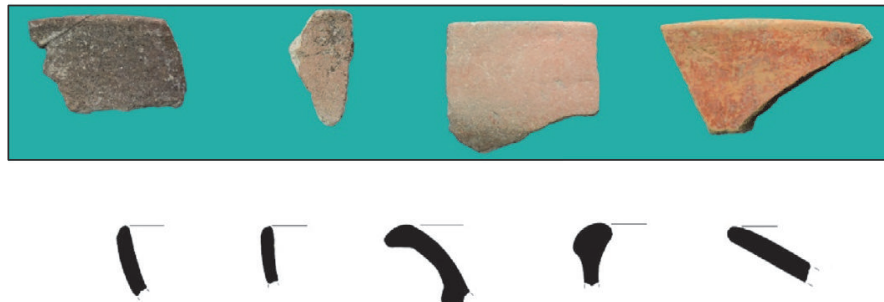

(i)

(j)
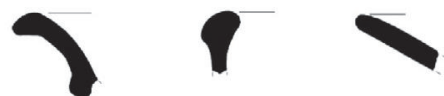

(k)

(1)

(m)
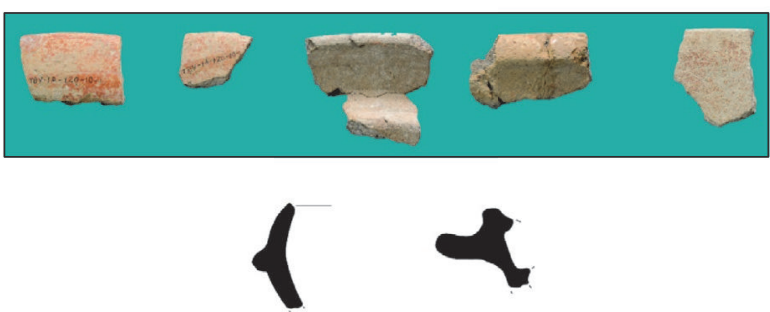

(n)

(o)

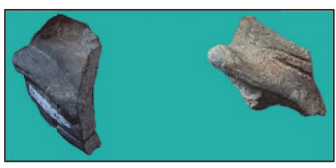

DIB: L. Luin

DIG/FOTO: C. Cruz

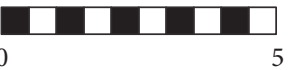

(cm)

Figure 23: Additional examples of Uck Red.

al. notes that red-on-cream/white pottery first appears at Ceibal in the Real 2 phase, correlating with its late appearance in the second half of the Cunil phase, so this type of bichrome decoration is a marker of the Real 2 or Late Cunil periods [43].

In K’axob, Northern Belize, McAnany and Lopez Varela illustrate Abelino Red and Toribio Red-on-Cream, but place them in the Early Chaakax Mamom complex ([118]: 151, Figure 3). This brings up the question of the relation between
Abelino Red of the Pasion region and Uck Red of Central Peten and Western Belize. Based on observation of the Pasion collections at Harvard and at the IDAEH Ceramoteca in Guatemala City, these two types are closely related in forms and slip qualities. Although some scholars consider these types highly distinct, in our opinion, they are part of closely linked traditions and show cultural continuity between the Real-Xe and the Eb-Cunil potters, as other scholars have also stressed $[1,4,6,7,60,67]$. 


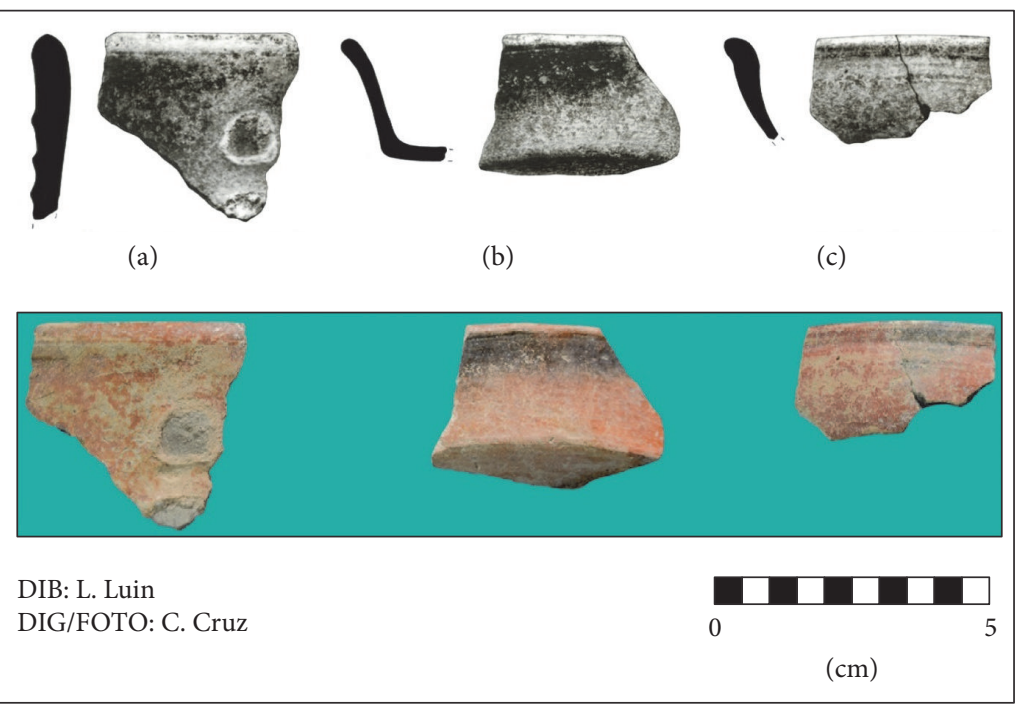

FIgURE 24: Examples of Uck Red.

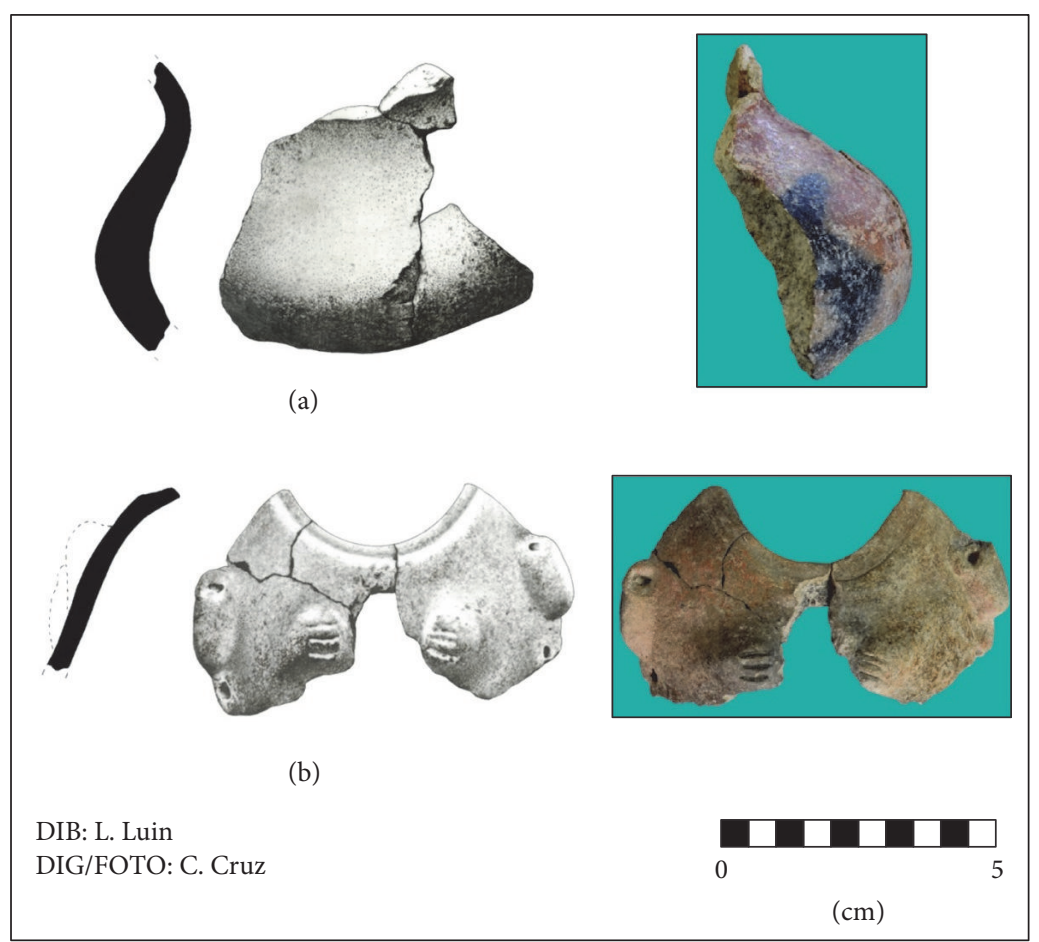

FIGURE 25: Specials in the Uck (Red) ceramic group.

The most common group of pre-Mamom slipped pottery at Buenavista-Nuevo San José is the Chi (Black) group (Figures 11, 30, and 31), originally defined by Awe and Cheetham at Cahal Pech $[59,61]$. The high incidence of the Chi group at Buenavista is atypical for the pre-Mamom horizon which is characterized by a higher preference for red slips [4]. However, the Xe complex at Altar de Sacrificios (which corresponds to the second half of the pre-Mamom horizon) also has significant black slipped pottery, more than red-slipped ([46]; [4]: Table 3.2). In addition, based on the recent excavations at Seibal, Inomata and colleagues have also found that black slipped pottery becomes more popular in the Late Real phase [43]. If this is true, the high frequency of Chi at Buenavista suggests that most of the early occupation at this site is from the second half of the pre-Mamom time period.

At Buenavista, the Chi paste is similar to that of Uck Red in being fine with fine to medium calcite, or volcanic ash temper, which makes the paste dark in some cases, but most often it is a yellowish-brown (7.5 YR 6/6). The pastes have wide black cores, suggestive of underfiring which may have allowed for the creation of the black slip. 


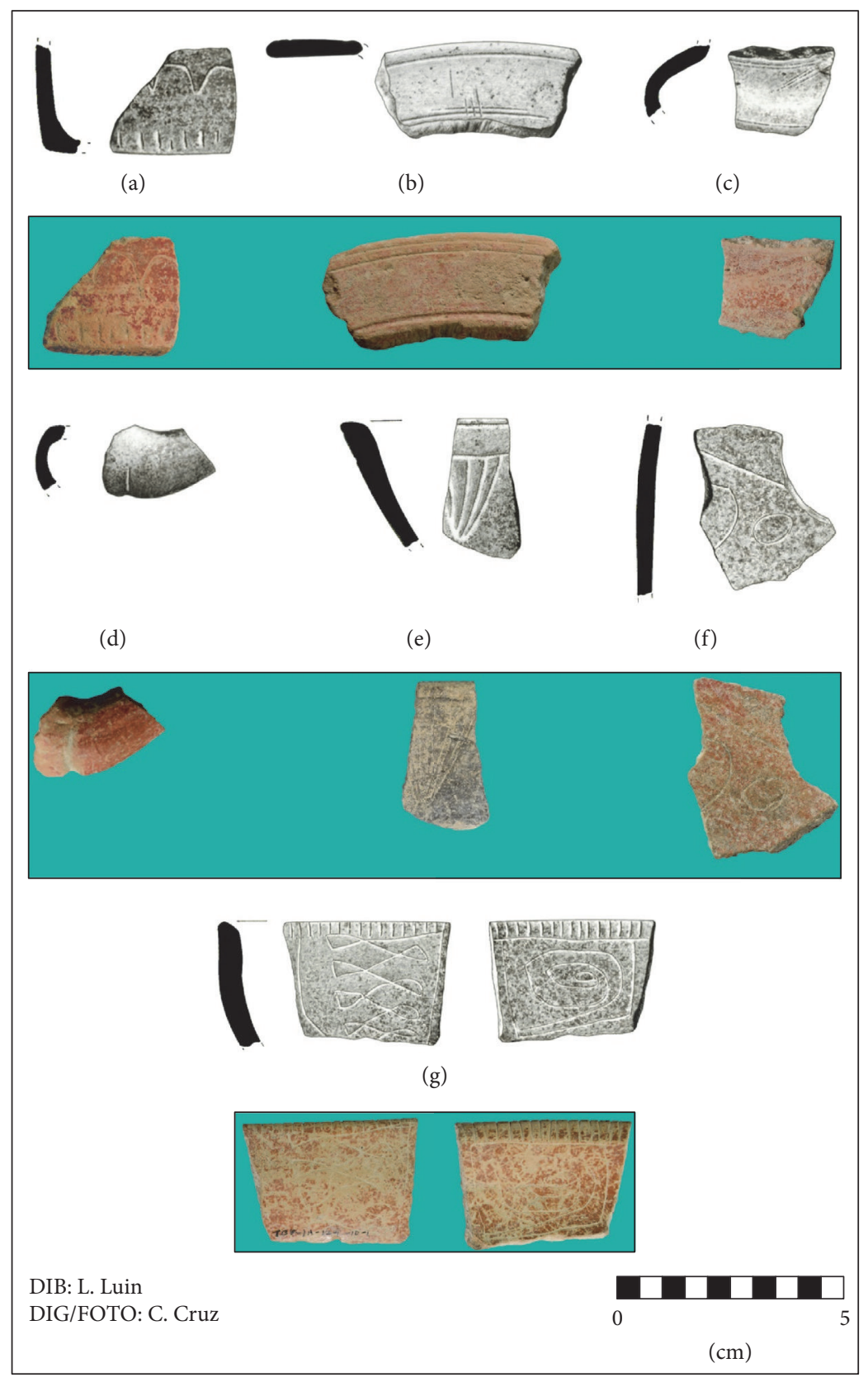

FIGURE 26: Kitam Incised of the Uck (Red) ceramic group.

The slip is dull grayish-yellowish-brown, matte, and milky (7.5 YR 5/3) and tends to dark brown-black (10 YR 3/1), found on both sides of the vessel. A few examples exhibited a more lustrous polished black slip. A fragment of the rim, neck, and collar of a jar had residues of specular hematite on the lip and collar. This brown-black slipped pottery has frequent postslip incised fine lines (Chi incised), at least at BuenavistaNuevo San José (Figures 30-31). The majority of the sample has one or two postslip incised or grooved ( $1 \mathrm{~mm}$ wide) lines below the rim on bowls and tecomates. A jar collar also had a circumferential postslip incised line on the body near the joint between the neck and body (Figure 31(c)).
More complex incised designs consist of inverted halfmoons, which may be parts of the avian serpent motif (Figures 30(b) and 31(a)), as well as inverted crosshatched triangles (Figure 30(c)). The most extraordinary example of Chi incised is a fragment of a flat base of a plate, on which a quadripartite symbol is incised after slip (Figure 11). This symbol represents the four directions or corners of the world, with the center of the cross representing the axis-mundi of the cosmos [119-122]. The quadripartite symbol also appears at Tikal [67], providing a direct connection between these two sites.

There were also more rare exemplars with light horizontal grooving (Chi Black: Grooved Variety), including a rim 


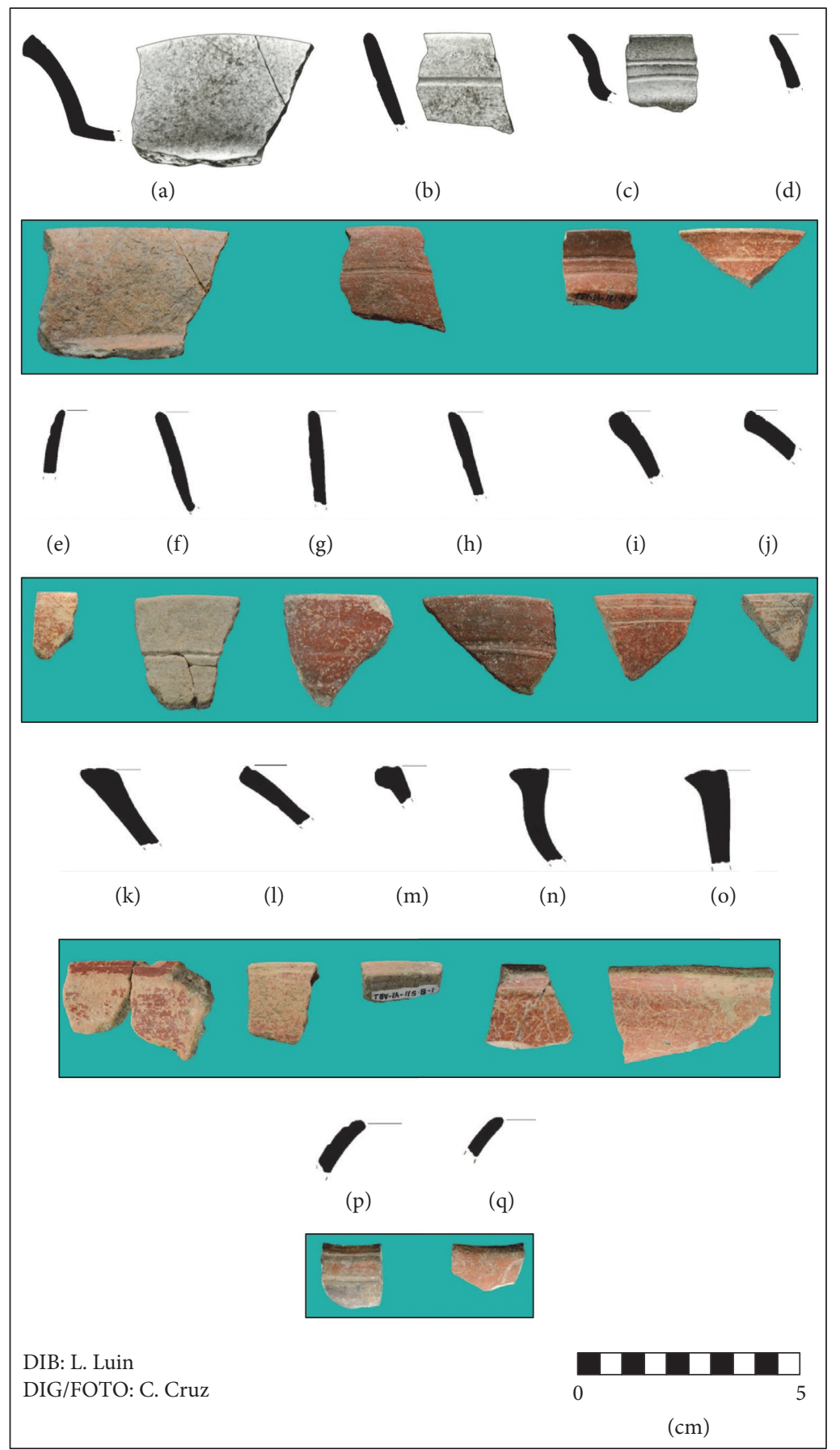

FIgURE 27: Additional examples of Kitam Incised (including grooved-incised).

grooved and painted red. Another example of a plate rim combines a circumferential groove with a circumferential incision directly below the rim on the exterior. Although rare, there were also sherds with chamfering. A unique rim had a perforation similar to an eye and a possible flame eyebrow.

The principal form of the Chi ceramic group is a plate with direct, beveled, or exterior-thickened rims; diameters between 10 and $26 \mathrm{~cm}$; heights between 2.4 and $4 \mathrm{~cm}$; flared thin $(7-8 \mathrm{~mm})$ walls; and flat bases. A few examples are deeper with heights reaching $5.5 \mathrm{~cm}$. Generally, these vessels are smaller and certainly shallower than comparable forms of the Mamom and Chicanel horizons. There are also bowls with direct, beveled, or exterior-thickened rims, slightly incurved sides, and very thick bases, either flat or rounded. Three examples of these bases show heavy use wear. Although rare, tecomates also appear; these have direct rims, diameters between 19 and $23 \mathrm{~cm}$, and strongly incurved walls. One example (Figure 31(b)) is similar to the tear-shaped tecomates described at Cahal Pech $[4,61]$. Also rare are small jars with rims between 6 and $16 \mathrm{~cm}$, sharp collars, and short necks 


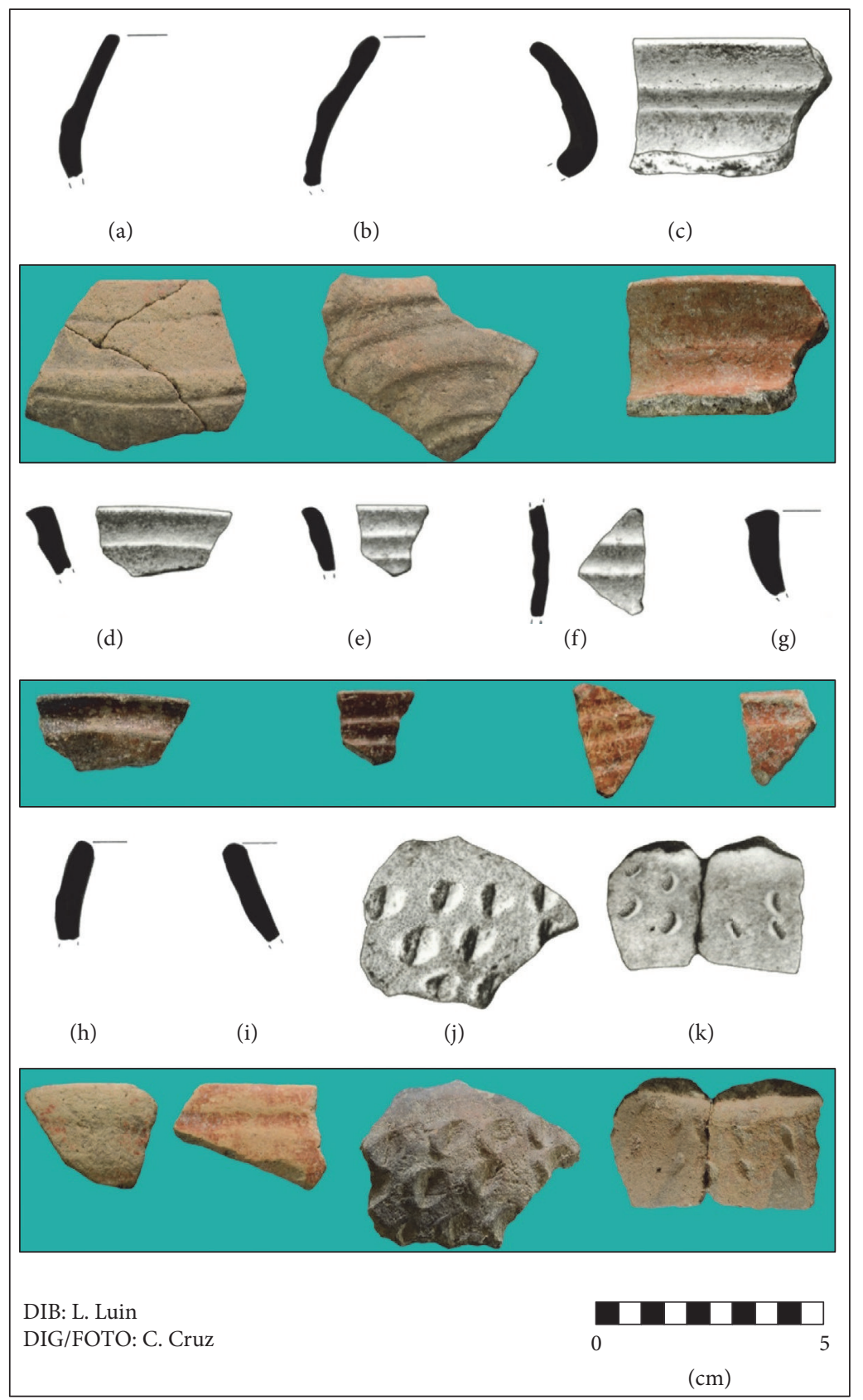

FIGURE 28: Other examples of the Uck (Red) ceramic group, including chamfering and impression/punctuation.

slightly outcurved (2.8-4.4 cm in height) and a wall thickness between 7 and $9 \mathrm{~mm}$.

Cheetham's recent reclassification of the Eb complex at Tikal has placed most of the black slipped Chunhinta material into the Chi (Black) group [67]. At least one sherd pertaining to this type but reported as Desprecio Incised from the Ah Pam collection of the Yaxha-Sacnab Lakes was published by Rice ([68]: Figure 4cc; [67]: 138).

Based on our sample, the Chi (Black) pottery of Buenavista-Nuevo San José is close in forms, surface finish, and decoration to the Crisanto group of the Real-Xe complexes in the Pasion region ([112]: 341-344, Figure 26; [46]: Figure laa, bb), where at least at Altar de Sacrificios it is a significant portion of the Xe complex (approximately $24 \%$ according to Cheetham ([4]: 30, Table 3.2)).

Most scholars see Chi Black as the predecessor of Chunhinta Black and Desprecio Incised of the Mamom horizon $[65,67]$. The slips of Chi Black are distinct from the glossy black slips of Machaca Black and Chacalte Incised of the contemporary Swasey complex at Cuello, although the latter type has similar incision to Chi, postslip, and postfire ([55]: 20, Figure 3.8b). Kosakowsky and Pring remark that Chacalte Incised: Chacalte Variety "is virtually indistinguishable from Chompipi Incised: Chompipi variety at Altar" ([117]: 63), a 


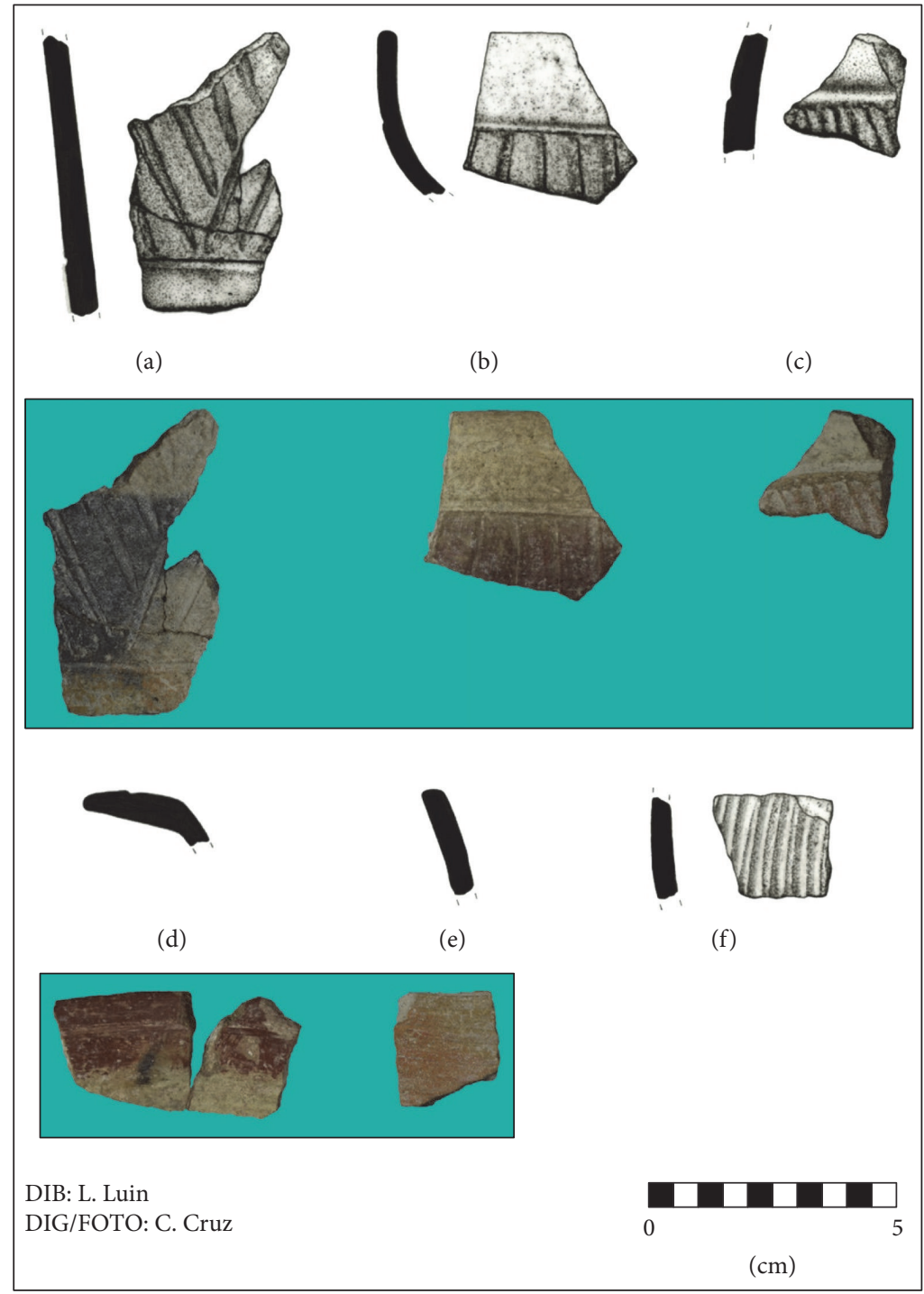

FIGURE 29: Rare Red-and-Cream Grooved pottery in the Uck ceramic group.

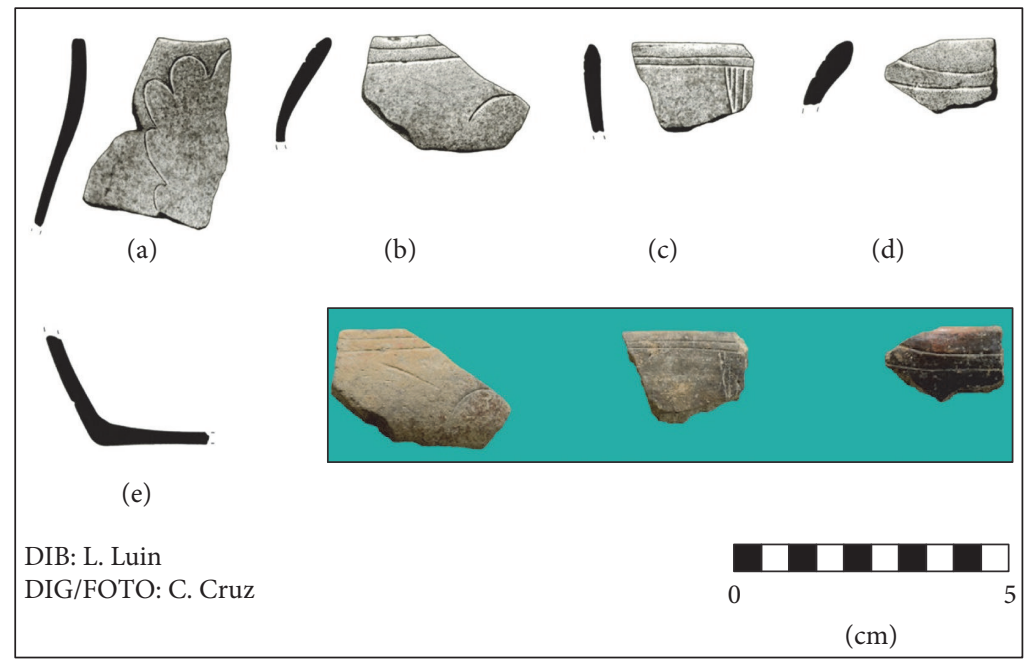

FIGURE 30: Examples of incised pottery of the Chi (Black) ceramic group. 


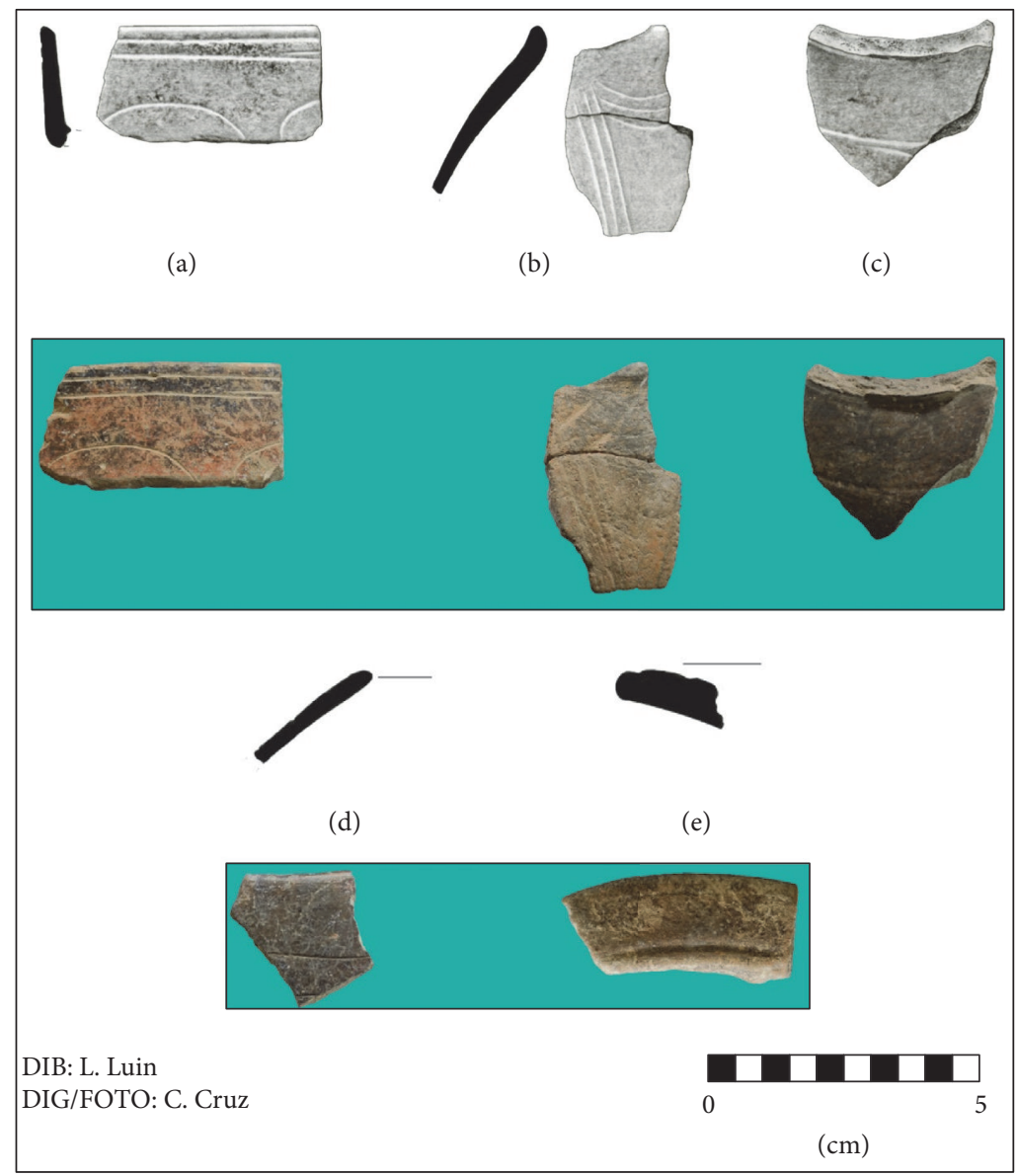

FIGURE 31: Additional examples of incised pottery of the Chi (Black) ceramic group.

type characteristic of the pre-Mamom Xe and Real complexes of the Pasion region. Such statements suggest that there are close connections between all pre-Mamom complexes in the southern Maya lowlands, as suggested originally by Cheetham [4].

The fifth group of slipped pottery, the Cocoyol (Cream) group, is much less frequent at Buenavista-Nuevo San José (Figures 32-33). It was defined by Awe and Cheetham at Cahal Pech $[59,61]$. Similar to Uck and Chi, the paste is fine and compact, with very fine calcite, and in some cases volcanic ash. Paste color varies from dark brown to reddish-brown (2.5 YR 4/6, 6/4, 7/3; 7.5 YR 4/6). All examples are well fired as none have dark centers. The Cocoyol group is characterized by a matte or dull slip generally yellowish-cream (10 YR 7/3 $8 / 2,8 / 3)$. The slip is thin and generally covers both sides of the vessels. Sometimes the slip appears to be simply a cream wash $(2.5 \mathrm{Y} \mathrm{8/2)}$, maybe due to erosion, through which the reddish paste is visible, creating a pinkish-cream or skin color. The main decoration consists of postslip fine incised lines in indeterminate designs. Some are clearly simple parallel lines, either horizontal or vertical, on the exterior and/or close to the rims of the vessels. On a plate with everted rim, two incisions are placed on the rim and a third below the rim on the interior (Figure 32(d)).
A more complex incised design appears on the exterior of a vase (Figure 32(a)), but it is geometric, combining horizontal and vertical lines, diagonal lines, downturned or "break" lines, and a circle. This design includes a partial music bracket or motif 11 (see description of this motif in [60]). A few extraordinary examples of the Cocoyol group (Figure 33) combine the cream slip on the exterior with specular hematite (10 R 4/4, 7.5 R 3/4) on the interior (or vice versa) and with fine postslip incisions $(1-3 \mathrm{~mm})$. The slips on these few examples are distinct from the cream and red slips described in the Uck group because the red slip is mixed with hematite and makes it sparkle. Only one vessel, a bowl or dish with flared walls and slightly rounded base, may be incised with the flame-eyebrow avian serpent design (Figure 33(b)).

Finally, a unique rim of a cream-slipped (10 YR 7/4) tecomate has a black $(2.5 \mathrm{Y} 4 / 0)$ rim created by differential firing (Figure 34 ). This could be a foreign import. We could observe similar examples from Altar de Sacrificios in the IDAEH Ceramoteca in Guatemala City.

Buenavista-Nuevo San José has few examples of the Cocoyol group, so it is hard to characterize its vessel forms. Nevertheless, among the sherds we found, we identified a plate with a wide everted rim, a tecomate with an interiorthickened rim, a bowl with direct rim and slightly incurved 


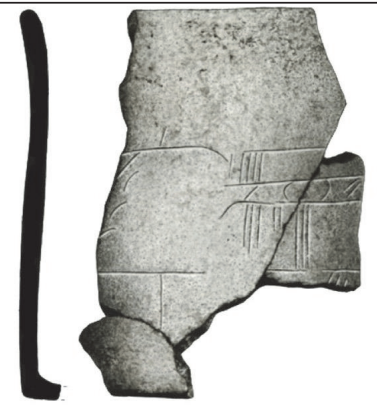

(a)

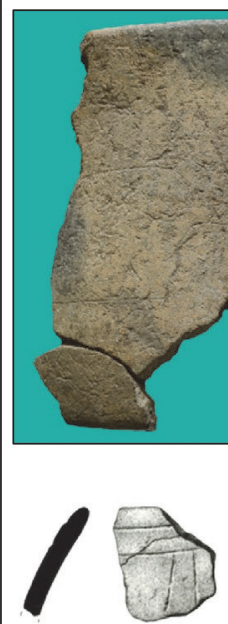

(c)

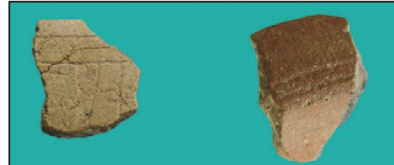

DIB: L. Luin

DIG/FOTO: C. Cruz

(d)

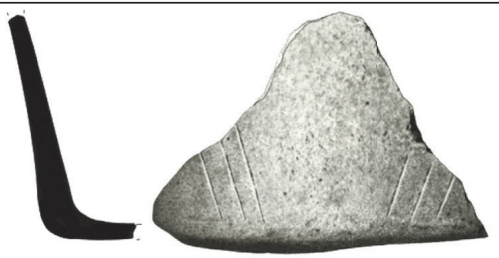

(b)
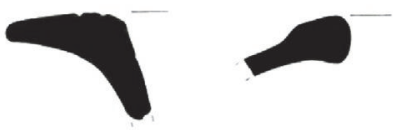

(e)

(f)

(g)
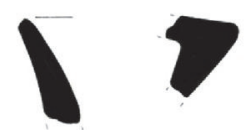

g)
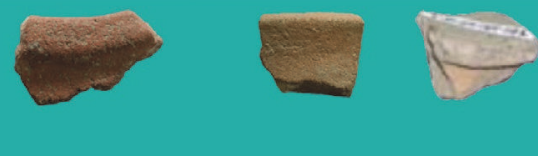

0

FIgURE 32: Examples of the Cocoyol (Cream) ceramic group.

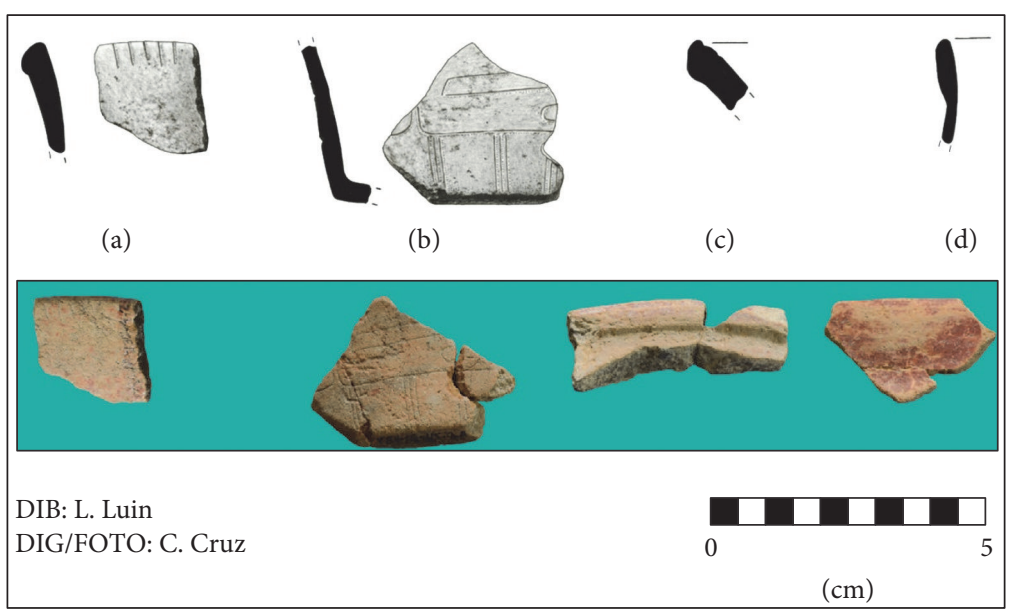

FIGURE 33: Specials from the Cocoyol (Cream) ceramic group: Hematite-and-Cream sherds. 


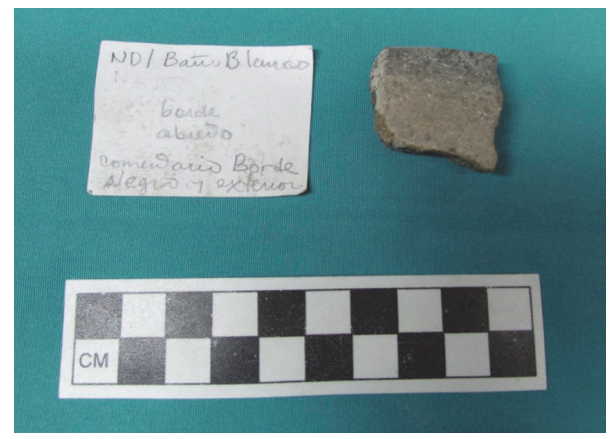

FIGURE 34: Specials from the Cocoyol (Cream) group: differentially fired black-and-white rim.

walls, and a dish or bowl with slight flared walls and rounded base. A final example is a vase with semicylindrical walls and semirounded base. We also have the middle section of a pot stand.

The Cocoyol (Cream) group may correspond to the infrequent type Bill White at Tikal, but Culbert underscores that this type has a "dead white" slip ([65]: E25, E26), while the Buenavista slips are generally cream, but with some variety. In his reanalysis of the Eb complex, Cheetham places the Bill White in Cocoyol Cream, noting the amount of variation in the thin, dull to low-polish slip, from white to gray to yellowish-red to greenish-brown ([67]: 63-64). We suspect that some examples of this group have been classified as Huetche, the Rio Pasion type, in the Central Peten Lakes region as Rice describes them as having a thin, eroded, stained, dull slip (10YR 8/1-8/2) of the same color as the Buenavista examples ([69]: 257, 264-265, Figures 139f-j; [67], 64-65). Furthermore, Rice [69] also mentions that some of these have remains of specular hematite, just like the few examples from Buenavista-Nuevo San José. Cocoyol Cream was also found at Yaxha-Sacnab as Rice describes the early pottery very close to our examples: "Thin, wash-like cream slips, distinct from the waxy slips of the Pital group, are reminiscent of Huetche White ceramics at Seibal" ([23]: 44). The high frequency of Huetche-like material at Nixtun-Ch'ich' connects this Lake Peten Itza site with the Pasion region, but we suspect that it is Cocoyol Cream, based on personal observation of this collection by Foias. The frequency of cream-slipped pottery at Nixtun-Ch'ich' is distinct from the pattern among the pre-Mamom assemblages at Tikal, Cahal Pech, and Buenavista, where cream-slipped pottery is uncommon.

The Cocoyol group is, indeed, the counterpart of Huetche White of the Real and Xe phases at Ceibal and Altar de Sacrificios ([112]: 225-237, Figures 16-17, 339-341, Figures 21-24; [46]: 25, Figure 1v, cc-ff). Huetche White at Seibal is similar to the Buenavista examples in that the slip is often thin, almost wash-like, allowing the reddish paste to come through, a feature also found at Buenavista. Contrary to the situation at Tikal, Cahal Pech, and Buenavista-Nuevo San José, pottery with dull white-cream slips is more frequent in the Pasion region [4]. Huetche represents $11-12 \%$ at Ceibal and Altar, respectively, while at Tikal and Cahal Pech, creamslipped pottery is only $1-2 \%$ of their respective complexes [4]. Cheetham [4] argues that this higher preference for whitecream slips in the Pasion region is due to more intense contact with the Chiapas region, where such pottery forms an important tradition.

Cocoyol Cream is present at Cahal Pech, but as just mentioned, in low frequencies, and bichromes (cream and red) are rare ([7]: 323). The Cocoyol paste at Cahal Pech is very distinct ("smooth creamy paste ... [with] a high percentage of volcanic ash") ([64]: 164), and it is unlike the Buenavista examples. Pottery with cream slips appears in North Belize in the Bladen complex as the Quamina group, but it is quite rare ([117]: 62).

In contrast to the relative low incidence of cream slips in the Maya lowlands, the tradition is dominant at this time in the central Mexican highlands, Gulf Coast, Pacific Coast, Chontalpa, and Chiapas ([67]: 67-69). Similarities between these non-Maya materials and Cocoyol is the dull, matte, and almost fugitive white-to-cream slips and even some forms are shared, such as the wide everted-rim plates [67]. In fact, Cheetham writes, "dull to low sheen white-slipped pottery (often incised) is found in virtually all regions of Mesoamerica during the 900-700 BC time frame. Its presence in the Maya lowlands in pre-Mamom contexts is a solid indicator of early interaction with neighboring regions" ([67]: 66). The unique example from Buenavista of a cream-slipped tecomate with a differentially fired black rim (see Figure 34) connects this site with the Gulf Coast and the Pacific Coast where differentially fired black and cream pottery is a strong tradition [67].

Cheetham [67] sees this group as the precursor of Pital Cream as defined at Uaxactun for the Mamom horizon ([111]: 161). Although this may true, we also want to point out that Cocoyol's wash-like cream slip which allows the paste color to come through, seems to intend the creation of a bichrome, in contrast to Pital Cream with its hard, thick waxy slip.

The final group of slipped ceramics remains unnamed: Unnamed Volcanic Ash (Gray-orange) Group (Figure 35). It is not even clear whether this group pertains to the Belize Valley Dull Ware. This material resembles $\mathrm{Cu}$ Orange and Savana Orange: Ash-Tempered Variety, as described by Cheetham [67], Brown [85], and Gifford [103]. We have chosen to leave the few sherds we found at Buenavista as unnamed until we are able to compare them directly with $\mathrm{Cu}$ Orange in the Belize Valley. The paste includes abundant fine volcanic ash and possibly mixed with very fine calcite. All have dark-gray cores. The paste color varies from light orange tonalities (7.5 YR 7/6) to more grayish tones. The sherds are very light weight, which may be due to leaching from acidic soils, or may be an inherent characteristic of the paste itself, a feature similar to the light weight of later Mars Orange. As the material is highly eroded, it is hard to say if these sherds were slipped or not. The main decoration consists of parallel lines either vertical or diagonal on the exterior of the vessels, or circumferential lines directly below the rims. One example may have tiny reed punctuation or impression (Figure 35(k)). Another vessel (Figure 35(1)) has a more complex design, which may be a part of the avian serpent motif. The sample 


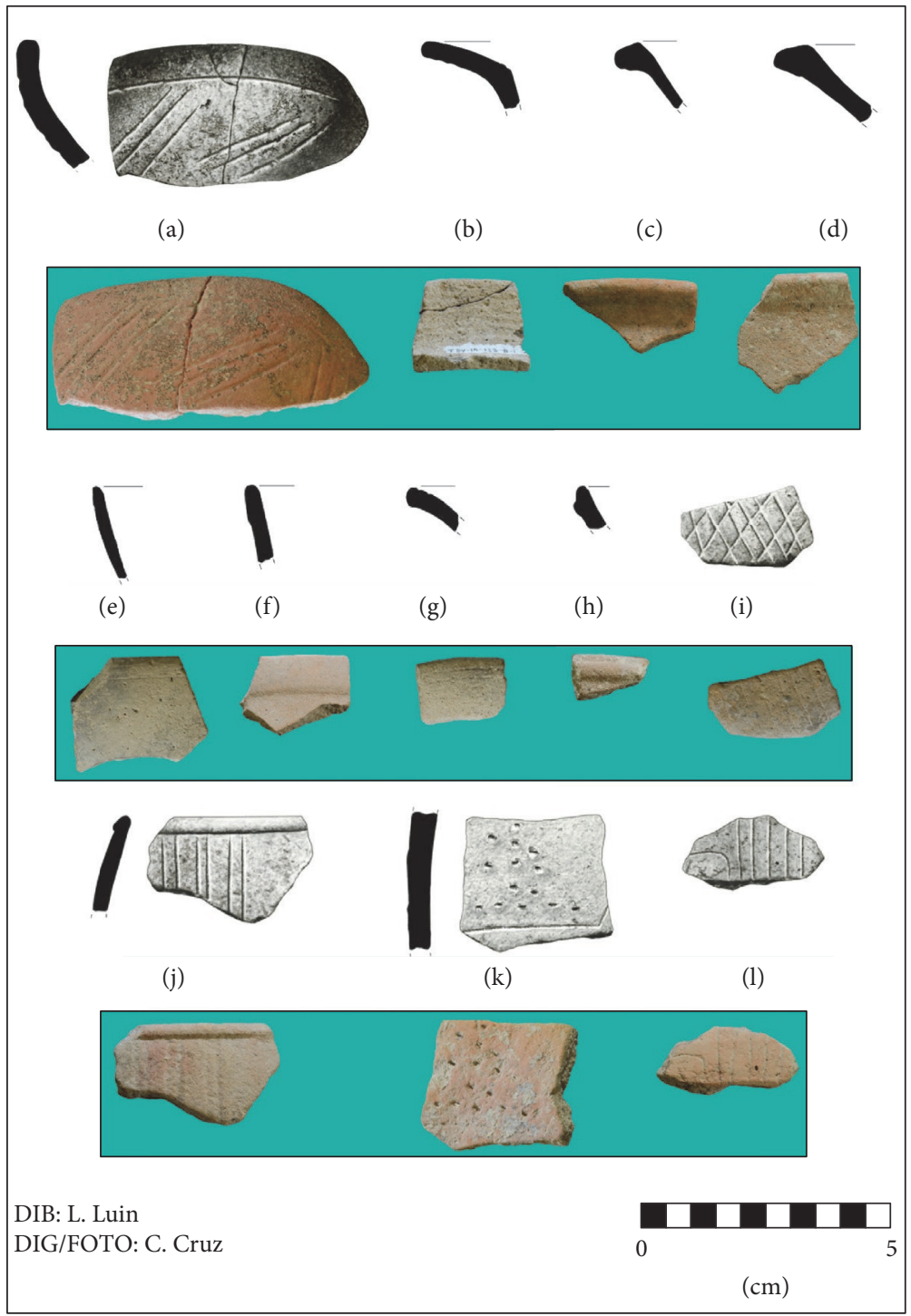

FIgURE 35: Examples of Unnamed Coarse Volcanic Ash, Group Unnamed Gray-Orange.

from Buenavista-Nuevo San José is extremely small, suggesting that it is an import. The majority of the sherds represent open serving vessel forms, and, according to the few rims, they are bowls with direct or exterior-thickened rims, slightly incurved walls, and possibly rounded bases.

At this point, it is hard to make comparisons with other sites. If indeed the Buenavista examples are $\mathrm{Cu}$ Orange or Savana Orange: Ash-tempered Variety, these types are very common in the Belize Valley, with $\mathrm{Cu}$ Orange as the predecessor of Mars Orange [4]. By the criterion of abundance, both $\mathrm{Cu}$ and Savana were likely produced in the Belize River Valley from where they were traded broadly into the rest of the Maya lowlands, although in small quantities.

$\mathrm{Cu}$ Orange also has a very fine volcanic ash temper, a gritty paste but yellowish-orange surfaces, and it is either unslipped or fire-clouded or has a black wash (which may explain why our examples have grayish-orange surfaces)
([67]: 87-88). In contrast to Cu Orange, Savana Orange: Ashtempered Variety has both calcite and ash inclusions, and its paste tends towards red, although there are also reddishbrown and yellowish-red or orange toned pastes ([67]: 8890). Savana Orange has a red wash, rather than the black wash of $\mathrm{Cu}$ Orange [67]. Based on this comparison of $\mathrm{Cu}$ and Savana Orange, the Buenavista examples seem to be closer to the former type which is diagnostic of the Cunil complex.

\section{Conclusions}

Current scholarship shows that, by $3400-1500$ BC, the southern Maya lowlands were sparsely populated by tribal societies, consisting of highly mobile horticulturalists-foragers or collectors $[1,7,19,27,123]$. Continuities in stone tool technologies from this time on support cultural continuity 
between these Late Archaic horticulturalists and the earliest sedentary pottery-making communities which were established in the southern Maya lowlands between 1000 and 800 BC $[1,13,14]$.

These first sedentary agricultural groups are identified by the earliest pottery traditions of the Maya lowlands: the Xe tradition in the Pasion region; the Cunil tradition of central and northern Belize; the Eb tradition of centralnorthern Peten; and the slightly later Swasey tradition in northern Belize. The cultural affiliations of and relationships between these four traditions remain under scrutiny, with some scholars seeing them as highly distinct [5], and other scholars proposing that they pertain to the same Cunil horizon (with the exception of Swasey) [4].

More recently, two aspects of the lifeways of these early Maya have been contested. Inomata et al. have argued convincingly that most Maya lowlanders may have remained relatively mobile for as long as two hundred years after the appearance of the first pottery in the Pasion, central-northern Peten, and Belize [43]. Furthermore, Lohse has reviewed the importance of maize in the earliest Maya burials and found that even the Mamom period populations did not depend on maize as much as in later times [1]. Therefore, it is possible that agriculture was not the mainstay of the pre-Mamom populations either. Our understanding of the Neolithic Revolution in the Maya lowlands has been transformed by these studies: no abrupt fracture from the pre-Neolithic occurs at $1000 \mathrm{BC}$ when pottery appears in the Maya lowlands; domesticates do not come in with pottery, but rather they had already been cultivated for hundreds of years, if not millennia; sedentism and nomadism coexisted for hundreds of years after pottery began to be used.

Currently, these critical centuries when sedentism and pottery were first introduced are known from only a handful of sites in central and northern Peten, and often from only a handful of sherds, often misclassified as Mamom pottery. These sites are Tikal, Uaxactun, Yaxha Hill, Ixtinto, Nixtun-Ch'ich', Ixlu, Trinidad de Nosotros, Holmul, Cival, and possibly Nakbe. Because of the rarity of pre-Mamom settlements, the discoveries at Buenavista-Nuevo San José on the north shore of Lake Peten Itza are important. These discoveries show that pre-Mamom settlements are buried underneath tiny sites as well as major ones, suggesting that human occupation was more widespread in this early time than we think. Excavations conducted by the Motul de San José Archaeological Project in 2001 and 2005 at BuenavistaNuevo San José showed a vibrant Middle Preclassic village that superseded a pre-Mamom settlement. This pre-Mamom occupation is made visible by the Eb-sphere pottery which we found in the deepest deposits at the site and by the possible remains of a post-in-bedrock dwelling which was covered by the subsequent substructures of Str. 4 .

The earliest pottery of Buenavista-Nuevo San José is closest to the Eb/Early Eb complex at Tikal in vessel forms, slip qualities, and paste characteristics [65-67]. We can, therefore, place it as a member of the Eb ceramic sphere of the pre-Mamom horizon. Furthermore, as Cheetham has argued, Tikal's Eb complex is closely connected to the Cunil ceramic traditions first identified at Cahal Pech and now found at other Belize River sites [4, 60, 67]. The similarities between the $\mathrm{Eb}$ and Cunil pottery detailed by Cheetham and his colleagues $[4,7,60,61,67]$ suggest that BuenavistaNuevo San José and the other central Peten pre-Mamom sites were in close contact with the Cunil sites of the Belize River Valley. At the same time, the Uck (Red), Chi (Black), and Cocoyol (Cream) groups are related to the similarly dull slips and vessel forms of the Abelino (Red), Crisanto (Black), and Huetche (White) groups of the Pasion region. In our opinion, these ties between the $\mathrm{Xe}, \mathrm{Eb}$, and Cunil ceramic spheres support Cheetham's, Clark's, and Lohse's proposals that these pre-Mamom lowlanders were part of the same Maya cultural tradition $[1,4,7]$.

The relationships between the $\mathrm{Xe}, \mathrm{Eb}$, and Cunil pottery are not as close in the unslipped cooking and storage pottery, as noted by several scholars $[4,5,7]$ : for example, compare the reconstructions of Real-Xe, Eb, and Cunil pottery in Figures 6-8 in Clark and Cheetham [7]. This is understandable within the social context of this early time period. The $\mathrm{Xe}, \mathrm{Eb}$, and Cunil communities were separated by long distances, and while contact must have been close, distinct customs must have also developed, maybe on the level of different tribal identities as suggested by Clark and Cheetham [7]. The differences between these traditions are indeed suggestive of interactions between them and adjacent non-Maya or highland regions: for example, the higher frequency of whiteslipped pottery in the Pasion Xe tradition than in the $\mathrm{Eb}$ or Cunil traditions indicates relationships with adjacent Chiapas, while the importance of the Jocote ceramic group and of its antecedent Ardagh Orange-Brown in the Cunil complex speaks to contact between Belize and the southeastern highlands $[4,5,64]$. But, in spite of these differences, the commonalities between the Buenavista-Nuevo San José preMamom pottery and the Eb, Cunil, and Xe traditions suggest that the earliest pottery-making communities of the southern Maya lowlands were all part of the same culture.

Furthermore, the complex incised symbols present on this early pottery in the Cunil, Eb, and Xe ceramic spheres are shared with the wider Mesoamerican cultural area and indicate that the earliest lowlanders were not isolated as previously believed, but rather fully immersed in a panMesoamerican ideological interaction sphere as argued by Cheetham, Garber, and Awe $[4,6,60]$. Cheetham has identified a number of motifs on the pre-Mamom pottery, which appear to have religious connotations, including lightning, shark tooth, music bracket, Kan cross, cleft head, flame eyebrow, double-line break, and avian serpent $[4,60]$. The Buenavista-Nuevo San José early pottery includes some of these symbols: we have identified six possible examples of the avian serpent, as well as one example each of the were-jaguar's cleft head, the music bracket, and the quadripartite motif. As such, this small settlement appears to be invested in the same interaction sphere as the inhabitants of Tikal and Cahal Pech.

Many of these motifs are well known as they are part of a horizon style which may have ultimately originated in the Olmec civilization of the Gulf Coast, from where it spread broadly in Mesoamerica in the Early to the Middle Formative ([60]: 12). The florescence of San Lorenzo between 1250 and 1000 BC had a deep impact on Mesoamerica 
as seen in the spread of the Early Olmec Horizon Style, while its subsequent decline and the rise of La Venta as the major Olmec center led to the spread of a second wave of Olmec or Olmecoid symbolism, dubbed the Late Olmec Horizon Style between 900 and 500 BC [60, 79-81, 124-128]. The most important of the Olmec or Olmecoid symbols in these horizon styles are mythological beings or supernatural entities: were-jaguars which are represented by their cleft heads, diagonal lines that meet, or the double-line break motif and sky dragons (fire serpents, avian serpents) which may be represented by flame eyebrows, paw-wing appendages, and trough-shaped eyes $[60,129]$. The were-jaguar may represent a feline supernatural tied to the earth and maize, while the sky dragon may be a reptilian supernatural of the sky realm [130-133].

Much ink has been spilled on whether the Early Olmec Horizon Style originated at San Lorenzo and then spread to the rest of Mesoamerica, the position promoted by those who argue that the Gulf Coast Olmecs were the "mother culture" of all other Mesoamerican civilizations [80, 125, 134]. The "mother-culture" model has evolved into two distinct threads, one that places great importance on elite emulation of the Gulf Coast Olmecs by other Mesoamerican groups and the second that accords the Gulf Coast Olmecs the role of an expanding empire [80,125, 135-137]. Critics of the "mother-culture" model believe that the Early Formative and Middle Formative Horizon Styles do not have one origin, but rather emerge out of interactions between sister cultures that share some basic religious beliefs which are then made visible through common motifs $[60,138-141]$. This position has also been called the peer-polity model in that the Formative Mesoamerican cultures are presumed to evolve together and develop jointly the iconography of the Early Formative Horizon $[81,138,142]$.

Cheetham maintains a middle ground by proposing that although these symbols appear first in the Olmec heartland, they are adopted in the Maya lowlands (and elsewhere in Mesoamerica) "only by virtue of local familiarity with the concepts/supernatural entities being portrayed, [but] not [with] the symbols themselves" ([60]: 47) (see also Lesure [143] in regard to the role of Olmec motifs in the Soconusco region). Paralleling a position close to the elite emulation model, Cheetham writes that, in the Maya lowlands and in regions beyond the Gulf Coast, charismatic leaders inscribed the Olmec/Olmecoid symbols in a highly visible manner on their serving ware as a powerful way to display their religious knowledge, which may have allowed these leaders to institutionalize their political aspirations to power by restricting access to the incised pottery as well as to the hidden meanings behind the stylized motifs [60]. The excavations at Cahal Pech do indeed show that among the four Cunilphase residences exposed in the immediate Plaza B, only one received more architectural elaboration and consumed more exotics (including jade and marine shell) and the special pottery incised with the Cunil-horizon motifs [60]. More recently, Rosenswig provides a rigorous review of the three models (peer-polity; elite emulation; Aztec-empireanalogy) applied to the role of the Gulf Coast Olmecs in Formative Mesoamerica [81]. Based on his excavations at the site of Cuauhtémoc in the Soconusco region of Chiapas, he concludes that the elite emulation model is the best in explaining the relationship between the Soconusco polities and the Gulf Coast Olmecs [81].

Resolving the debate on the origins of the Early and Late Olmec Horizons is beyond the scope of this paper, but the new discoveries of pre-Mamom pottery incised with Earlyto-Late Olmec/Olmecoid symbols, and the new research on the significant pre-Mamom ceremonial architecture at Ceibal in the Pasion region cast further doubt on the simple "mother-culture" perspective. Cheetham was the first to note the presence of the Olmecoid symbols on pre-Mamom pottery found in the Belize River Valley, the Pasion, and the central Peten [60]. Lohse's and Inomata and his colleagues' efforts to accurately place the pre-Mamom pottery in absolute time allow us to state that the incised Olmec/Olmecoid symbols appear between 1000 and 800 BC [1-3, 43]. On the Gulf Coast, these two centuries mark important transformations as San Lorenzo was in decline by 1000 BC (or even earlier, 1150 BC, [2]), and La Venta did not enter its Golden Age until after $800 \mathrm{BC}[2,80,81,144]$. If this revised chronology is correct, San Lorenzo is too early to be the direct source of the Cunil-horizon symbolism, while La Venta postdates the pre-Mamom horizon and again cannot be the source of these pre-Mamom motifs.

The construction of an E-group at Ceibal at the beginning of the Real phase (or around 1000-950 BC [2]) also poses problems for the "mother-culture" model of the Gulf Coast Olmecs. The origins of the E-group spatial plan lie in Central Chiapas, and not in the Olmec heartland. Many Middle Formative sites in Central Chiapas, including Mirador, San Isidro, Chiapa de Corzo, and Finca Acapulco, have this site plan which has been named the Middle Formative Chiapas (MFC) pattern by Clark and Hansen $[2,145]$. However, the majority of these are built later than at Ceibal, c. 800-700 BC, possibly with the exception of Chiapa de Corzo and Finca Acapulco $[2,146,147]$. Inomata and his colleagues look to Ojo de Agua, a major Jocotal-phase site on the Pacific Coast of Chiapas (1150-1000 BC), as the possible origin of the MFC plan as its impressive "pyramids, substantial platforms, and plazas exhibit a vague resemblance to the MFC pattern" ([2]: 470). All of this discussion is to say that San Lorenzo was not the origin of the E-group plan, while La Venta's E-group arrangement is too late to explain the early constructions at Ceibal [2]. The E-group plan becomes widespread in the Maya lowlands in the subsequent Late Middle Preclassic and Late Preclassic times, so that some scholars had suggested that the Maya adopted it from the Gulf Coast Olmecs $[145,148]$. In view of the recent discoveries at Ceibal, this is untenable. The early construction of an E-group at Ceibal shows strong two-way interaction between the Pasion Maya and Chiapas, as Inomata et al. have stressed, and not with the Gulf Coast Olmecs [2, 43]. And, even so, the Ceibal Maya, put their own twist on the MFC complex as, instead of emphasizing the northsouth axis as the Chiapas centers do ([145]: 4), they shifted the focus to the eastwest direction $[2,43]$. While the tallest platform is located in the north in the MFC plan ([145]: 4), the Maya made the western platform the highest building in the complex $[2,43,86]$. We agree with Inomata and his 
colleagues that the emerging picture of the earliest potteryusing farmers in the Maya lowlands suggests a complex mixture of autochthonous development and interregional interaction, where the Gulf Coast Olmecs were only one of many political actors. At the same time, there is now sufficient evidence for the Archaic occupation of the Maya lowlands to suggest that the earliest sedentary and potteryproducing farmers of the southern Maya lowlands were the descendants of these Archaic horticulturalists, and probably already Maya ethnically and/or culturally. More excavations of the deepest layers of occupation at Maya sites, both major and minor, like Buenavista-Nuevo San José, are needed in order to reconstruct more fully the lifeways of these first farmers of the heartland of Maya civilization in central Peten.

\section{Disclosure}

The authors declare any mistakes in this final version as their own.

\section{Competing Interests}

The authors declare that they have no competing interests.

\section{Acknowledgments}

The authors would like to thank the following funding agencies for their support of the research reported here: NSF (Grant no. SBR-9905456) to A. Foias and K. Emery and FAMSI (Grant no. 05039) to J. Castellanos, as well as Williams College whose support made the Motul de San José Archaeological Project possible. They thank the Guatemalan Institute of Anthropology and History for their permission to conduct archaeological investigations at Buenavista-Nuevo San José. Numerous other individuals contributed to the success of this research, through logistical assistance during the field seasons and through their specific expertise, including Kitty Emery, Matthew Moriarty, Christina Halperin, Erin Thornton, and Crorey Lawton. Fernando Luin and Carlos Cruz helped tremendously in illustrating the pottery and in designing/digitizing the figures, respectively. They are grateful to David Cheetham who examined the whole Buenavista-Nuevo San José ceramic collection in 2006 and confirmed the presence of Cunil-related pottery. He has also provided advice and access to unpublished materials. Finally, they want to thank all of their workers from San José and Nuevo San José for their hard labor and dedication during the many field seasons we conducted in the Lake Peten Itza region. They are deeply grateful to David Cheetham, Takeshi Inomata, and Rob Rosenswig, who read versions of this paper and provided many suggestions for improvement.

\section{References}

[1] J. C. Lohse, "Archaic origins of the Lowland Maya," Latin American Antiquity, vol. 21, no. 3, pp. 312-352, 2010.

[2] T. Inomata, D. Triadan, K. Aoyama, V. Castillo, and H. Yonenobu, "Early ceremonial constructions at Ceibal, Guatemala, and the origins of lowland Maya civilization," Science, vol. 340, no. 6131, pp. 467-471, 2013.
[3] T. Inomata, R. Ortiz, B. Arroyo, and E. J. Robinson, "Chronological revision of Preclassic Kaminaljuyú, Guatemala: implications for social processes in the Southern Maya Area," Latin American Antiquity, vol. 25, no. 4, pp. 377-408, 2014.

[4] D. Cheetham, "Cunil: a pre-Mamom horizon in the Southern Maya Lowlands," in New Perspectives on Formative Mesoamerican Cultures, T. G. Powis, Ed., vol. 1377 of BAR International Series, pp. 27-38, British Archaeological Reports, Oxford, UK, 2005.

[5] J. W. Ball and J. T. Taschek, "Reconsidering the Belize Valley Preclassic: a case for multiethnic interactions in the development of a regional culture tradition," Ancient Mesoamerica, vol. 14, no. 2, pp. 179-217, 2003.

[6] J. F. Garber and J. J. Awe, "A Terminal Early Formative symbol system in the Maya lowlands: the iconography of the Cunil phase (1100-900BC) at Cahal Pech," Reports in Belizean Archaeology, vol. 6, pp. 151-159, 2009.

[7] J. E. Clark and D. Cheetham, "Mesoamerica's tribal foundations," in The Archaeology of Tribal Societies, W. A. Parkinson, Ed., vol. 15 of Archaeological Series, pp. 278-339, International Monographs in Prehistory, Ann Arbor, Mich, USA, 2002.

[8] D. E. Puleston and O. S. Puleston, "An ecological approach to the origins of Maya civilization," Archaeology, vol. 24, pp. 330$337,1971$.

[9] T. G. Garrison and N. P. Dunning, "Settlement, environment, and politics in the San Bartolo-Xultun Territory, El Peten, Guatemala," Latin American Antiquity, vol. 20, no. 4, pp. 525552, 2009.

[10] R. D. Hansen, S. Bozarth, J. Jacob, D. Wahl, and T. Schreiner, "Climatic and environmental variability in the rise of Maya civilization: a preliminary perspective from Northern Peten," Ancient Mesoamerica, vol. 13, no. 2, pp. 273-295, 2002.

[11] D. Wahl, R. Byrne, T. Schreiner, and R. Hansen, "Holocene vegetation change in the northern Peten and its implications for Maya prehistory," Quaternary Research, vol. 65, no. 3, pp. 380389, 2006.

[12] J. S. Jacob, "Ancient Maya wetland agricultural fields in Cobweb Swamp, Belize: construction, chronology, and function," Journal of Field Archaeology, vol. 22, no. 2, pp. 175-190, 1995.

[13] H. B. Iceland, The Preceramic origins of the Maya: the results of the Colha Preceramic project in Northern Belize [Ph.D. dissertation], Department of Anthropology, University of Texas at Austin, 1997.

[14] J. C. Lohse, J. Awe, C. Griffith, R. M. Rosenswig, and F. Valdez Jr., "Preceramic occupations in Belize: updating the Paleoindian and Archaic record," Latin American Antiquity, vol. 17, no. 2, pp. 209-226, 2006.

[15] R. M. Rosenswig, "A mosaic of adaptation: the archaeological record for Mesoamerica's Archaic period," Journal of Archaeological Research, vol. 23, no. 2, pp. 115-162, 2015.

[16] R. N. Zeitlin and J. F. Zeitlin, "The Paleoindian and Archaic cultures of Mesoamerica," in The Cambridge History of the Native Peoples of the Americas, R. E. W. Adams and M. MacLeod, Eds., vol. 2, pp. 45-121, Cambridge University, New York, NY, USA, 2000.

[17] T. Beach, N. Dunning, S. Luzzadder-Beach, D. E. Cook, and J. Lohse, "Impacts of the ancient Maya on soils and soil erosion in the central Maya Lowlands," Catena, vol. 65, no. 2, pp. 166-178, 2006.

[18] J. G. Jones, "Pollen evidence for early settlement and agriculture in northern Belize," Palynology, vol. 18, pp. 205-211, 1994. 
[19] M. D. Pohl, K. O. Pope, J. G. Jones et al., "Early agriculture in the Maya Lowlands," Latin American Antiquity, vol. 7, no. 4, pp. 355-372, 1996.

[20] N. Dunning, D. J. Rue, T. Beach, A. Covich, and A. Traverse, "Human-environment interactions in a tropical watershed: the paleoecology of Laguna Tamarindito, El Petén, Guatemala," Journal of Field Archaeology, vol. 25, no. 2, pp. 139-151, 1998.

[21] U. M. Cowgill and G. E. Hutchinson, "El Bajo de Santa Fé," Transactions of the American Philosophical Society, vol. 53, no. 7, pp. 3-51, 1963.

[22] U. Cowgill and G. E. Hutchinson, "The chemical history of Laguna de Petenxil, El Peten, Guatemala," Connecticut Academy of Arts and Sciences Memoir, New Haven, vol. 17, 1966.

[23] D. S. Rice, "Middle Preclassic Maya settlement in the central Maya lowlands," Journal of Field Archaeology, vol. 3, no. 4, pp. 425-445, 1976.

[24] E. S. Deevey, D. S. Rice, P. M. Rice, H. H. Vaughan, M. Brenner, and M. S. Flannery, "Mayan urbanism: impact on a tropical karst environment," Science, vol. 206, no. 4416, pp. 298-306, 1979.

[25] E. S. Deevey Jr., M. Brenner, and M. W. Binford, "Paleolimnology of the Peten Lake district, Guatemala, III: Late Pleistocene and Gamblian environments of the Maya area," Hydrobiologia, vol. 103, no. 1, pp. 211-216, 1983.

[26] M. Brenner, M. F. Rosenmeier, D. A. Hodell, and J. H. Curtis, "Paleolimnology of the Maya Lowlands: Long-term perspectives on interactions among climate, environment, and humans," Ancient Mesoamerica, vol. 13, no. 1, pp. 141-157, 2002.

[27] J. H. Curtis, M. Brenner, D. A. Hodell, R. A. Balser, G. A. Islebe, and H. Hooghiemstra, "A multi-proxy study of Holocene environmental change in the Maya Lowlands of Peten, Guatemala," Journal of Paleolimnology, vol. 19, no. 2, pp. 139-159, 1998.

[28] F. S. Anselmetti, D. A. Hodell, D. Ariztequi, M. Brenner, and M. F. Rosenmeier, "Quantification of soil erosion rates related to ancient Maya deforestation," Geology, vol. 35, no. 10, pp. 915918, 2007.

[29] A. D. Mueller, G. A. Islebe, M. B. Hillesheim et al., "Climate drying and associated forest decline in the lowlands of northern Guatemala during the late Holocene," Quaternary Research, vol. 71, no. 2, pp. 133-141, 2009.

[30] M. F. Rosenmeier, D. A. Hodell, M. Brenner, J. H. Curtis, and T. P. Guilderson, "A 4000-year lacustrine record of environmental change in the southern Maya lowlands, Petén, Guatemala," Quaternary Research, vol. 57, no. 2, pp. 183-190, 2002.

[31] M. B. Hillesheim, D. A. Hodell, B. W. Leyden et al., "Climate change in lowland central America during the Late Deglacial and Early Holocene," Journal of Quaternary Science, vol. 20, no. 4, pp. 363-376, 2005.

[32] H. B. Iceland, "The Preceramic to Early Middle Formative transition in Northern Belize: evidence for the ethnic identity of the Preceramic inhabitants," in New Perspectives on Formative Mesoamerican Cultures, T. G. Powis, Ed., vol. 1377 of $B A R$ International Series, pp. 15-26, 2005.

[33] E. C. Gibson, "A preliminary functional and contextual study of constricted adzes from Northern Belize," in Proceedings of the Maya Stone Tools: Selected Papers from the Second Maya Lithic Conference, T. R. Hester and H. J. Shafer, Eds., pp. 229237, Prehistory Press, 1991.

[34] T. R. Hester, H. B. Iceland, D. B. Hudler, and H. J. Shafer, "The Colha Preceramic Project: preliminary results from the 19931995 field seasons," Mexicon, vol. 18, pp. 45-50, 1996.
[35] R. M. Rosenswig, "The Late Archaic occupation of Northern Belize: new archaeological excavation data," in Research Reports in Belizean Archaeology, vol. 1, pp. 267-277, Institute of Archaeology, NICH, Belize City, Belize, 2004.

[36] R. M. Rosenswig and M. A. Masson, "Seven new preceramic sites documented in Northern Belize," Mexicon, vol. 23, pp. 138140, 2001.

[37] R. M. Rosenswig, D. M. Pearsall, M. A. Masson, B. J. Culleton, and D. J. Kennett, "Archaic period settlement and subsistence in the Maya lowlands: new starch grain and lithic data from Freshwater Creek, Belize," Journal of Archaeological Science, vol. 41, pp. 308-321, 2014.

[38] R. Hansen, "Continuity and disjunction: the Pre-Classic antecedents of Classic Maya architecture," in Function and Meaning in Classic Maya Architecture, S. D. Houston, Ed., pp. 49-122, Dumbarton Oaks, Washington, DC, USA, 1998.

[39] P. M. Rice, "Mound ZZ1, Nixtun-Ch'ich', Petén, Guatemala: rescue operations at a long-lived structure in the Maya Lowlands," Journal of Field Archaeology, vol. 34, no. 4, pp. 403-422, 2009.

[40] T. W. Killion, "Nonagricultural cultivation and social complexity: the Olmec, their ancestors, and Mexico's southern Gulf Coast lowlands," Current Anthropology, vol. 54, no. 5, pp. 569606, 2013.

[41] P. J. Arnold III, "Settlement and subsistence among the Early Formative Gulf Olmec," Journal of Anthropological Archaeology, vol. 28, no. 4, pp. 397-411, 2009.

[42] R. M. Rosenswig, A. M. VanDerwarker, B. J. Culleton, and D. J. Kennett, "Is it agriculture yet? Intensified maize-use at $1000 \mathrm{cal}$ BC in the Soconusco and Mesoamerica," Journal of Anthropological Archaeology, vol. 40, pp. 89-108, 2015.

[43] T. Inomata, J. MacLellan, D. Triadan et al., "Development of sedentary communities in the Maya lowlands: coexisting mobile groups and public ceremonies at Ceibal, Guatemala," Proceedings of the National Academy of Sciences of the United States of America, vol. 112, no. 14, pp. 4268-4273, 2015.

[44] F. S. Anselmetti, D. Ariztegui, D. A. Hodell et al., "Late Quaternary climate-induced lake level variations in Lake Petén Itzá, Guatemala, inferred from seismic stratigraphic analysis," Palaeogeography, Palaeoclimatology, Palaeoecology, vol. 230, no. 1-2, pp. 52-69, 2006.

[45] E. W. Andrews, "The early ceramic history of the lowland Maya," in Vision and Revision in Maya Studies, F. Clancy and P. D. Harrison, Eds., pp. 1-19, University of New Mexico Press, Alburquerque, Spain, 1990.

[46] R. E. W. Adams, The Ceramics of Altar De Sacrificios, Guatemala, vol. 63, no. 1, Harvard University, Cambridge, Mass, USA, 1971, Papers of the Peabody Museum of Archaeology and Ethnology.

[47] R. J. Sharer and J. C. Gifford, "Preclassic ceramics from Chalchuapa, El Salvador, and their relationships with the Maya Lowlands," American Antiquity, vol. 35, no. 4, pp. 441-462, 1970.

[48] G. R. Willey, "The rise of Maya civilization: a summary view," in The Origins of Maya Civilization, R. E. W. Adams, Ed., pp. 383423, University of New Mexico Press, Albuquerque, NM, USA, 1977.

[49] N. Hammond, “The earliest Maya," Scientific American, vol. 236, no. 3, pp. 116-133, 1977.

[50] N. Hammond, Ed., Cuello: An Early Maya Community in Belize, Cambridge University Press, Cambridge, UK, 1991.

[51] N. Hammond, S. Donaghey, R. Berger, S. De Atley, V. R. Switsur, and A. P. Ward, "Maya Formative phase radiocarbon dates from Belize," Nature, vol. 267, pp. 608-610, 1977. 
[52] N. Hammond and C. H. Miksicek, "Ecology and economy of a Formative Maya site at Cuello, Belize," Journal of Field Archaeology, vol. 8, no. 3, pp. 259-269, 1981.

[53] N. Hammond, A. Clarke, and S. Donaghey, "The long goodbye: Middle Preclassic Maya archaeology at Cuello, Belize," Latin American Antiquity, vol. 6, no. 2, pp. 120-128, 1995.

[54] E. W. Andrews V and N. Hammond, "Redefinition of the Swasey phase at Cuello, Belize," American Antiquity, vol. 55, no. 3, pp. 570-584, 1990.

[55] L. J. Kosakowsky, Preclassic Maya Pottery at Cuello, Belize, Anthropological Papers of the University of Arizona, No. 47, University of Arizona, Tucson, Ariz, USA, 1987.

[56] J. A. Sabloff, "Excavations at Seibal, Department of Peten, Guatemala: ceramics," in Memoirs of the Peabody Museum of Archaeology and Ethnology, vol. 13, no. 12, Harvard University, Cambridge, Mass, USA, 1975.

[57] B. R. Bachand, “The Pre-classic ceramic sequence of Punta De Chimino, Petén, Guatemala," Mayab, vol. 19, pp. 5-26, 2007.

[58] K. J. Johnston, "Preclassic Maya occupation of the Itzan escarpment, lower Río de la Pasión, Petén, Guatemala," Ancient Mesoamerica, vol. 17, no. 2, pp. 177-201, 2006.

[59] J. Awe, Dawn in the land between the rivers: Formative occupation Cahal Pech, Belize and its implications to Preclassic development in the central Maya lowlands [Ph.D. dissertation], Institute of Archaeology, University College of London, 1992.

[60] D. Cheetham, Interregional interaction, symbol emulation and the emergence of socio-political inequality in the central Maya lowlands [M.S. thesis], Department of Anthropology and Sociology, University of British Columbia, Vancouver, Canada, 1998.

[61] D. Cheetham, D. W. Forsyth, and J. E. Clark, "La cerámica Pre-mamom de la cuenca del río Belice y del centro de Peten: Las correspondencias y sus implicaciones," in XVI Simposio de Investigaciones Arqueológicas en Guatemala, 2002, J. P. Laporte, B. Arroyo, H. L. Escobedo, and H. Mejía, Eds., pp. 609-634, Museo Nacional de Arqueología y Etnología, Guatemala City, Guatemala, 2003.

[62] J. F. Garber, M. K. Brown, J. J. Awe, and C. J. Hartman, "Middle Formative prehistory of the central Belize valley: an examination of architecture, material culture, and sociopolitical change at Blackman Eddy," in The Ancient Maya of the Belize Valley: Half a Century of Archaeological Research, J. F. Garber, Ed., pp. 25-47, University Press of Florida, Gainesville, Fla, USA, 2004.

[63] P. F. Healy, D. Cheetham, T. G. Powis, and J. J. Awe, "Cahal Pech: the Middle Formative period," in The Ancient Maya of the Belize Valley: Half a Century of Archaeological Research, J. F. Garber, Ed., pp. 103-124, University Press of Florida, Gainesville, Fla, USA, 2004.

[64] L. A. Sullivan, M. K. Brown, and J. J. Awe, "Refining the Cunil ceramic complex at Cahal Pech, Belize," in Research Reports in Belizean Archaeology, vol. 6, pp. 161-168, Institute of Archaeology, NICH, Belize City, Belize, 2009.

[65] T. P. Culbert, "Ceramics of Tikal: Eb, Tzec, Chuen and Manik complexes," Manuscript, Department of Anthropology, University of Arizona, Tucson, 1979.

[66] T. P. Culbert, The Ceramics of Tikal: Vessels from the Burials, Caches and Problematical Deposits, Tikal Reports vol. 25, part A, University Museum, Monograph 81, University of Pennsylvania, Philadelphia, Pa, USA, 1993.

[67] D. Cheetham, The Eb Ceramic Complex and Early Interregional Interaction at Tikal, Guatemala, Papers of the New World
Archaeological Foundation, Brigham Young University, Provo, Utah, USA, 2016.

[68] P. M. Rice, "Ceramic and nonceramic artifacts of lakes YaxhaSacnab, El Peten, Guatemala, part I, the ceramics, section A, Introduction and middle preclassic ceramics of Yaxha-Sacnab, Guatemala," Cerámica de Cultura Maya, vol. 10, pp. 1-36, 1979.

[69] P. M. Rice, "La cerámica del Proyecto Maya Colonial," in Proyecto Maya Colonial: Geografía Política del Siglo XVII en el Centro del Peten, Guatemala. Informe Preliminar al Instituto de Antropología e Historia de Guatemala Sobre Investigaciones del Campo en los Años 1994 y 1995, D. S. Rice, P. Rice, R. Sánchez Polo, and G. D. Jones, Eds., pp. 247-318, 1996.

[70] M. D. Moriarty, "History, politics, and ceramics: the ceramic sequence of trinidad de nosotros, el peten, guatemala," in Motul de San José: Politics, History, and Economy in a Classic Maya Polity, A. E. Foias and K. F. Emery, Eds., pp. 194-228, University Press of Florida, Gainesville, Fla, USA, 2012.

[71] M. Callaghan, "La cerámica de la región de holmul peten: análisis preliminar," in XX Simposio de Investigaciones Arqueológicas en Guatemala, 2006, J. P. Laporte, B. Arroyo, and H. E. Mejía, Eds., pp. 1346-1362, Museo Nacional de Arqueología y Etnología, Guatemala City, Guatemala, 2007.

[72] R. D. Hansen, "Perspectives on Olmec-Maya interaction in the Middle Formative period," in New Perspectives on Formative Mesoamerican Cultures, T. G. Powis, Ed., BAR International Series No. 1377, pp. 51-72, British Archaeological Reports, Oxford, UK, 2005.

[73] J. Gifford, "The earliest and other intrusive population elements at Barton Ramie may have come from central America," Ceramica de Cultura Maya, vol. 6, pp. 1-10, 1970.

[74] L. Campbell and T. Kaufman, "A linguistic look at the Olmecs," American Antiquity, vol. 41, no. 1, pp. 80-89, 1976.

[75] T. Kaufman, "Archaeological and linguistic correlations in mayaland and associated areas of mesoamerica," World Archaeology, vol. 8, pp. 101-118, 1976.

[76] S. Wichmann, "A conservative look at diffusion involving Mixe-zoquean languages," in Archaeology and Language II: Correlating Archaeological and Linguistic Hypotheses, R. Blench and M. Spriggs, Eds., pp. 297-323, Routledge Press, New York, NY, USA, 1998.

[77] S. Houston, J. Robertson, and D. Stuart, "The language of Classic Maya inscriptions," Current Anthropology, vol. 41, no. 3, pp. 321356, 2000.

[78] T. P. Culbert, "The ceramics of Tikal," in Tikal: Dynasties, Foreigners, and Affairs of State, J. A. Sabloff, Ed., pp. 47-81, School of American Research Press, James Currey, Santa Fe, NM, USA, 2003.

[79] R. J. Sharer and D. Grove, Eds., Regional Perspectives on the Olmec, Cambridge University Press, Cambridge, UK, 1989.

[80] J. E. Clark and M. E. Pye, Eds., Olmec Art and Archaeology in Mesoamerica, Studies in the History of Art no. 58, Center for Advanced Study in the Visual Arts, National Gallery of Art, Yale University Press, New Haven, Conn, USA, 2000.

[81] R. M. Rosenswig, The Beginnings of Mesoamerican Civilization: Inter-Regional Interaction and the Olmec, Cambridge University Press, New York, NY, USA, 2000.

[82] G. R. Willey, The Altar de Sacrificios Excavations: General Summary and Conclusions, vol. 64, no. 3, Harvard University, Cambridge, Mass, USA, 1973, Papers of the Peabody Museum of Archaeology and Ethnology. 
[83] G. R. Willey, Excavations at Seibal, Department of Peten, Guatemala: General Summary and Conclusions, vol. 17, no. 4 of Memoirs of the Peabody Museum of Archaeology and Ethnology, Harvard University, Cambridge, UK, 1990.

[84] G. R. Willey, A. L. Smith, G. Tourtellot III, and I. Graham, Excavations at Seibal, Department of Peten, Guatemala: Introduction: The Site and Its Setting, vol. 13, no. 1, Harvard University, Cambridge, Mass, USA, 1975, Memoirs of the Peabody Museum of Archaeology and Ethnology.

[85] M. K. Brown, Ritual Ceramics in the Early and Middle Preclassic at the sites of Blackman Eddy and Cahal Pech, Belize, Report to the Foundation for the Advancement of Mesoamerican Studies Inc (FAMSI), electronic document, 2007, http://www.famsi.org/ reports/02066.

[86] T. Inomata and D. Triadan, "Middle Preclassic caches from Ceibal, Guatemala," Maya Archaeology, vol. 3, pp. 56-90, 2015.

[87] T. G. Powis and D. Cheetham, "From house to holy: Formative development of civic-ceremonial architecture in the Maya Lowlands," in Proceedings of the Annual Meetings of the Society for American Archaeology, San Juan, Puerto Rico, April 2006.

[88] A. Foias, "Perspectivas teóricas y la dinámica del estado Clásico Maya: resultados preliminares del Proyecto Motul de San José 1988-2003," Mayab, vol. 16, pp. 15-32, 2003.

[89] K. F. Emery, "Natural resources use and Classic Maya economics: environmental archaeology at Motul de San José, Guatemala," Mayab, vol. 16, pp. 33-48, 2003.

[90] M. D. Moriarty, "Settlement archaeology at Motul de San José, Peten, Guatemala. Preliminary results from the 1998-2003 seasons," Mayab, vol. 17, pp. 21-44, 2004.

[91] A. E. Foias and K. F. Emery, Eds., Motul de San José: Politics, History, and Economy in a Classic Maya Polity, University Press of Florida, Gainesville, Fla, USA, 2012.

[92] J. E. Castellanos and F. Guffey, "Excavaciones en un centro secundario de Motul de San José: Buenavista," in Proyecto Arqueológico Motul de San José Informe \#4, Temporada de Campo 2001, A. E. Foias, Ed., pp. 67-85, Institute of Anthropology and History, Guatemala City, Guatemala, 2001, http://motul-archaeology.williams.edu/excavation.

[93] J. E. Castellanos, Buenavista-Nuevo San José, Peten, Guatemala: Otra Aldea del Preclásico Medio (800-400 a.C.), Foundation for the Advancement of Mesoamerican Studies Inc (FAMSI), 2007, http://www.famsi.org/reports/05039es/.

[94] J. E. Castellanos, "Informe temporada de campo junioagosto 2055, Buenavista-Nuevo San José, Peten, Guatemala," in Proyecto Arqueológico Motul de San José Informe \#7, Temporada de Campo 2005-2006, M. Moriarty, E. Spensley, J. Castellanos, and A. Foias, Eds., pp. 9-36, Institute of Anthropology and History, Guatemala City, Guatemala, 2007, http://motul-archaeology.williams.edu/excavation.

[95] P. A. McAnany, Ancestral Maya Economies in Archaeological Perspective, Cambridge University Press, New York, NY, USA, 2010.

[96] J. F. Garber, "Patterns of jade consumption and disposal at Cerros, Northern Belize," American Antiquity, vol. 48, no. 4, pp. 800-807, 1983.

[97] W. R. Coe, Piedras Negras Archaeology: Artifacts, Caches and Burials, University Museum Monograph 18, University of Pennsylvania, Philadelphia, Pa, USA, 1959.

[98] M. J. Becker, "Earth offerings among the Classic period Lowland Maya: burials and caches as ritual deposits," in Perspectivas
Antropológicas en el Mundo Maya, J. Iglesias Ponce de León and F. Ligorred Perramon, Eds., no. 2, pp. 45-74, Publicaciones de ls Sociedad Española de Estudios Mayas, Girona, España, 1993.

[99] R. Joyce, "Ideology in action: Classic Maya ritual practice," in Proceedings of the 23rd Annual Chaccmool Conference Ancient Images, Ancient Thought: Archaeology of Ideology, A. S. Goldsmith, S. Garvie, D. Selin, and J. Smith, Eds., pp. 497-505, Archaeological Association of the University of Calgary, 1992.

[100] R. Joyce, "Archaeology of ritual and symbolism," in International Encyclopedia of the Social and Behavioral Sciences, N. J. Smelser and P. B. Baltes, Eds., vol. 20, pp. 13371-13375, Elsevier, Oxford, UK, 2001.

[101] R. E. Smith, G. R. Willey, and J. C. Gifford, "The type-variety concept as a basis for the analysis of Maya pottery," American Antiquity, vol. 25, no. 3, pp. 330-340, 1960.

[102] J. A. Sabloff and R. E. Smith, "The Importance of both analytic and taxonomic classification in the type-variety system," American Antiquity, vol. 34, no. 3, pp. 278-285, 1969.

[103] J. C. Gifford, Prehistoric Pottery Analysis and the Ceramics of Barton Ramie in the Belize Valley, vol. 18 of Memoirs of the Peabody Museum of Archaeology and Ethnology, Harvard University, Cambridge, UK, 1976.

[104] D. W. Forsyth, The Ceramics of El Mirador, Peten, Guatemala, El Mirador Series, part 4, no. 63, Brigham Young University, Provo, Utah, USA, Papers of the New World Archaeological Foundation, 1989.

[105] D. W. Forsyth, "The ceramic sequence at Nakbe, Guatemala," Ancient Mesoamerica, vol. 4, no. 1, pp. 31-53, 1993.

[106] D. W. Forsyth, "La secuencia cerámica de la Isla de Flores, Peten," Mayab, vol. 10, pp. 5-14, 1996.

[107] A. E. Foias and R. L. Bishop, "Changing ceramic production and exchange in the Petexbatun region, Guatemala: reconsidering the Classic Maya collapse," Ancient Mesoamerica, vol. 8, no. 2, pp. 275-291, 1997.

[108] A. E. Foias and R. L. Bishop, Ceramics, Production and Exchange in the Petexbatun Region: The Economic Parameters of the Classic Maya Collapse, VIMA Petexbatun Monograph Series No. 7, Vanderbilt University Press, Nashville, Tenn, USA, 2013.

[109] J. P. Laporte and V. Fialko, "Análisis cerámico de tres depósitos problemáticos de fase Eb, Mundo Perdido, Tikal," in Tikal y Uaxactun en el Preclásico, J. P. Laporte and J. A. Valdés, Eds., pp. 53-69, Instituto de Investigaciones Antropologicas, Universidad Nacional Autónoma de México, Mexico City, Mexico, 1993.

[110] J. P. Laporte and V. Fialko, "Un reencuentro con Mundo Perdido, Tikal, Guatemala," Ancient Mesoamerica, vol. 6, pp. 4194, 1995.

[111] R. E. Smith and J. Gifford, Maya Ceramic Varieties, Types and Wares at Uaxactun: Supplement to 'Ceramic Sequence at Uaxactun, Guatemala', vol. 28 of Middle American Research Institute Publication, Tulane University, New Orleans, Louis, USA, 1966.

[112] G. R. Willey, "The Real Xe ceramics of Seibal, Peten, Guatemala," in Monographs and Papers in Maya Archaeology, W. R. Bullard Jr., Ed., vol. 61 of Papers of the Peabody Museum of Archaeology and Ethnology, pp. 313-355, Harvard University, 1970.

[113] A. F. Chase, A contextual consideration of the Tayasal-Paxcaman zone, El Peten Guatemala [Ph.D. dissertation], Department of Anthropology, University of Pennsylvania, Philadelphia, Pa, USA, 1983. 
[114] J. P. Laporte, "Una actualización a la secuencia cerámica del Area de Dolores, Peten," in Atlas Arqueológico de Guatemala: Algunos Resultados de Investigación, no. 3, J. P. Laporte, Ed., pp. 35-64, Ministerio de Cultura y Deportes, IDAEH, KfW Kreditanstalt fur Wiederaufbau, Guatemala City, Guatemala, 1995.

[115] A. F. Chase, "Regional development in the Tayasal-Paxcaman Zone, El Peten, Guatemala: a preliminary statement," Cerámica de Cultura Maya, vol. 11, pp. 86-119, 1979.

[116] B. Hermes, "Industria cerámica," in El Sitio Maya de Topoxte: Investigaciones en una Isla del lago Yaxhá, Peten, Guatemala, W. W. Wurster, Ed., pp. 164-202, Kommission für Allgemeine und Vergleichende Archäologie des Deutschen archäologischen Instituts, Bonn, Germany, 2000.

[117] L. J. Kosakowsky and D. Pring, "Ceramic chronology and typology," in Cuello: An Early Maya Community in Belize, N. Hammond, Ed., pp. 60-69, Cambridge University Press, Cambridge, UK, 1991.

[118] P. A. McAnany and S. L. López Varela, "Re-creating the Formative Maya village of K'axob: chronology, ceramic complexes, and ancestors in architectural context," Ancient Mesoamerica, vol. 10, no. 1, pp. 147-168, 1999.

[119] W. Ashmore, "La dirección norte en la arquitectura Precolombina del Sureste de Mesoamérica," Yaxkin, vol. 11, no. 1, pp. 83107, 1988.

[120] W. Ashmore, "Site-planning principles and concepts of directionality among the ancient Maya," Latin American Antiquity, vol. 2, no. 3, pp. 199-226, 1991.

[121] V. R. Bricker, "Directional glyphs in Maya inscriptions and codices," American Antiquity, vol. 48, no. 2, pp. 347-353, 1983.

[122] C. Coggins, "The shape of time: some political implications of a four-part figure," American Antiquity, vol. 45, no. 4, pp. 727-739, 1980.

[123] N. Hammond, "Recovering Maya civilisation," Proceedings of the British Academy, vol. 151, pp. 361-385, 2007.

[124] J. E. Clark, "Una Reevaluacion de la Entidad Politica Olmeca: Imperio, Estado, o Cacicazgo?" in Segundo y Tercer Foro de Arqueologia de Chiapas, T. A. Lee Jr., Ed., pp. 159-169, Instituto Chiapaneco de Cultura, Tuxtla Gutiérrez, Mexico, 1993.

[125] J. E. Clark, "The arts of government in early Mesoamerica," Annual Review of Anthropology, vol. 26, pp. 211-234, 1997.

[126] J. E. Clark and M. Blake, "El origen de la civilización en Mesoamerica: los Olmecas y Mokoya del Soconusco de Chiapas, Mexico," in El Preclasico o Formativo: Avances y Perspectivas, M. C. Macias, Ed., pp. 385-403, Museo Nacional de Antropologia, Mexico City, Mexico, 1989.

[127] G. W. Lowe, "The heartland Olmec: evolution of material culture," in Regional Perspectives on the Olmec, R. J. Sharer and D. C. Grove, Eds., pp. 33-67, Cambridge University Press, Cambridge, Mass, USA, 1989.

[128] C. A. Pool, Olmec Archaeology and Early Mesoamerica, Cambridge University Press, Cambridge, UK, 2007.

[129] F. K. Reilly III, "Art, ritual, and rulership in the Olmec world," in The Olmec World: Ritual and Rulership, J. Kerr and B. M. White, Eds., pp. 27-45, The Art Museum, Princeton University, Princeton, NJ, USA, 1995.

[130] N. M. Pyne, "The fire-serpent and were-jaguar in Formative Oaxaca: a contingency table analysis," in The Early Mesoamerican Village, K. V. Flannery, Ed., pp. 272-282, Academic Press, New York, NY, USA, 1976.
[131] J. Marcus, "Zapotec chiefdoms and the nature of Formative religions," in Regional Perspectives on the Olmec, J. Sharer and C. Grove, Eds., pp. 148-197, Cambrigde University Press, Cambridge, UK, 1989.

[132] K. A. Taube, "Lightning celts and corn fetishes: the Formative Olmec and the development of maize symbolism in Mesoamerica and the American Southwest," in Olmec Art and Archaeology in Mesoamerica, J. E. Clark and M. E. Pye, Eds., pp. 297-337, National Gallery of Art, Washington, DC, USA, 2000.

[133] B. L. Stark, "Out of Olmec," in The Political Economy of Ancient Mesoamerica: Transformations during the Formative and Classic Periods, V. L. Scarborough and J. E. Clark, Eds., pp. 47-63, University of New Mexico Press, Albuquerque, NM, USA, 2007.

[134] P. Tolstoy, "Coapexco and Tlatilco: sites with Olmec materials in the Basin of Mexico," in Regional Perspectives on the Olmec, R. J. Sharer and D. C. Grove, Eds., pp. 85-121, Cambridge University Press, Cambridge, Mass, USA, 1989.

[135] J. P. Blomster, Etlatongo: Social Complexity, Interaction, and Village Life in the Mixteca Alta of Oaxaca, Mexico, Wadsworth, Belmont, Calif, USA, 2004.

[136] P. Tolstoy, "Western Mesoamerica and the Olmec," in Regional Perspectives on the Olmec, R. J. Sharer and D. C. Grove, Eds., pp. 275-302, Cambridge University Press, Cambridge, UK, 1989.

[137] J. E. Clark, "Mesoamerica's first state," in The Political Economy of Ancient Mesoamerica: Transformations during the Formative and Classic Periods, V. L. Scarborough and J. E. Clark, Eds., pp. 11-48, University of New Mexico Press, Albuquerque, NM, USA, 2007.

[138] D. C. Grove, "Olmec: what's in a name?" in Regional Perspectives on the Olmec, R. J. Sharer and D. C. Grove, Eds., pp. 8-14, Cambridge University Press, Cambridge, Mass, USA, 1989.

[139] D. C. Grove, "Olmec archaeology: a half century of research and its accomplishments," Journal of World Prehistory, vol. 11, no. 1, pp. 51-101, 1997.

[140] K. V. Flannery and J. Marcus, Early Formative Pottery of the Valley of Oaxaca, vol. 27 of Memoirs of the Museum of Anthropology, University of Michigan, Ann Arbor, Mich, USA, 1994.

[141] A. A. Demarest, "The Olmec and the rise of civilization in Eastern Mesoamerica," in Regional Perspectives on the Olmec, R. J. Sharer and D. C. Grove, Eds., pp. 303-344, Cambridge University Press, Cambridge, UK, 1989.

[142] J. Marcus and K. V. Flannery, Zapotec Civilization: How Urban Society Evolved in Mexico's Oaxaca Valley, Thames and Hudson, London, UK, 1996.

[143] R. G. Lesure, "Animal imagery, cultural unities, and ideologies of inequality in Early Formative Mesoamerica," in Olmec Art and Archaeology in Mesoamerica, Studies in the History of Art no. 58, pp. 193-215, Center for Advanced Study in the Visual Arts, National Gallery of Art, Yale University Press, New Haven, Conn, USA, 2000.

[144] M. Coe and R. A. Diehl, The Land of the Olmec, University of Texas Press, Austin, Tex, USA, 1980.

[145] J. E. Clark and R. D. Hansen, "Architecture of early kingship: comparative perspectives on the origins of the Maya royal court," in Royal Courts of the Ancient Maya, Volume 2: Data and Case Studies, T. Inomata and S. D. Houston, Eds., pp. 1-45, Westview Press, Boulder, Colo, USA, 2001.

[146] A. J. McDonald, Tzutzuculi: A Middle-Preclassic Site on the Pacific Coast of Chiapas, Mexico, vol. 47 of Papers of the New World Archaeological Foundation, Brigham Young University, Provo, Utah, USA, 1983. 
[147] D. B. Bryant, J. E. Clark, and D. Cheetham, Ceramic Sequence of the Upper Grijalva Region, Chiapas, Mexico, vol. 67 of Papers of the New World Archaeological Foundation, Brigham Young University, Provo, Utah, USA, 2005.

[148] G. W. Lowe, "The Mixe-Zoque as competing neighbors of the Early Lowland Maya," in The Origins of Maya Civilization, R. E. W. Adams, Ed., pp. 197-248, University of New Mexico Press, Albuquerque, NM, USA, 1977.

[149] M. Stuiver and P. J. Reimer, "Extended C14 data base and revised CALIB 3.0 14C age calibration program," Radiocarbon, vol. 35, no. 1, pp. 215-230, 1993.

[150] P. J. Reimer, M. G. L. Baillie, E. Bard et al., "IntCal04 terrestrial radiocarbon age calibration, 0-26 cal kyr BP," Radiocarbon, vol. 46, no. 3, pp. 1029-1058, 2004. 


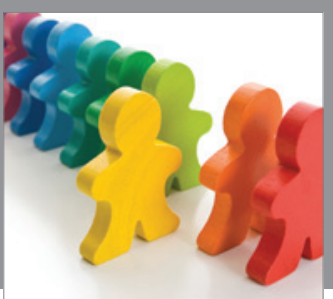

Autism

Research and Treatment
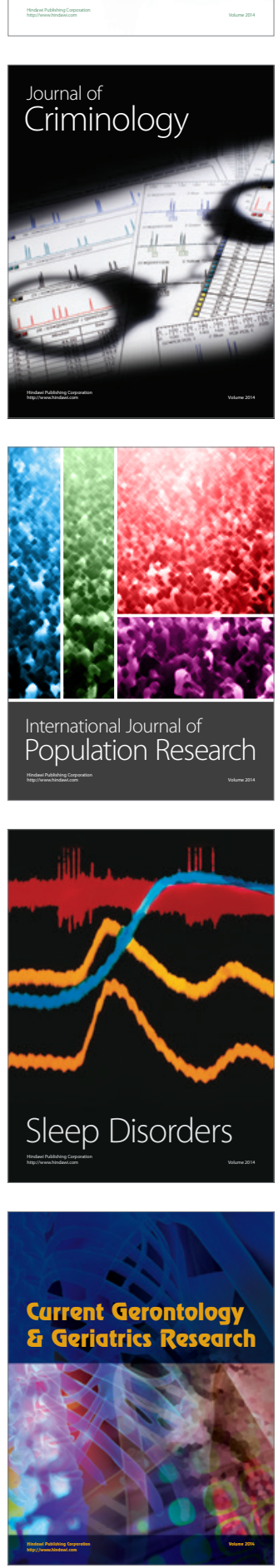

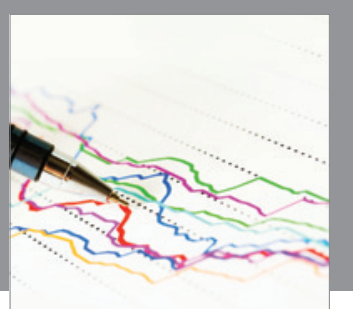

Economics

Research International
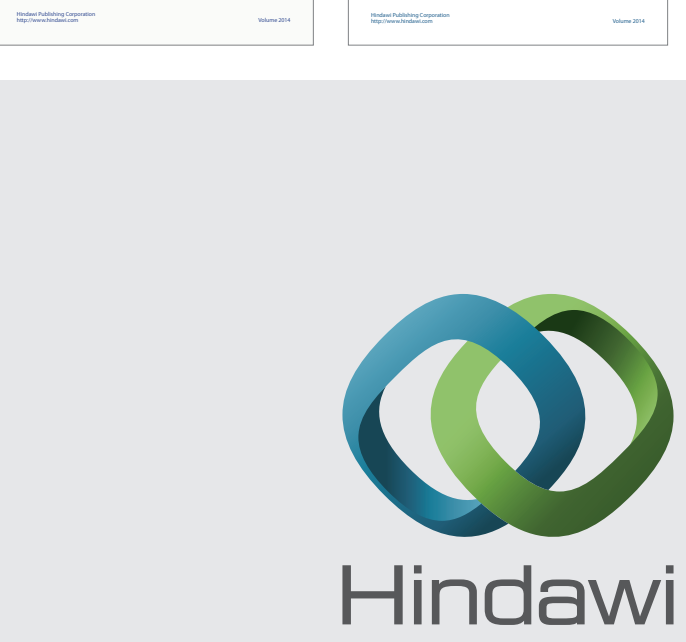

Submit your manuscripts at

https://www.hindawi.com
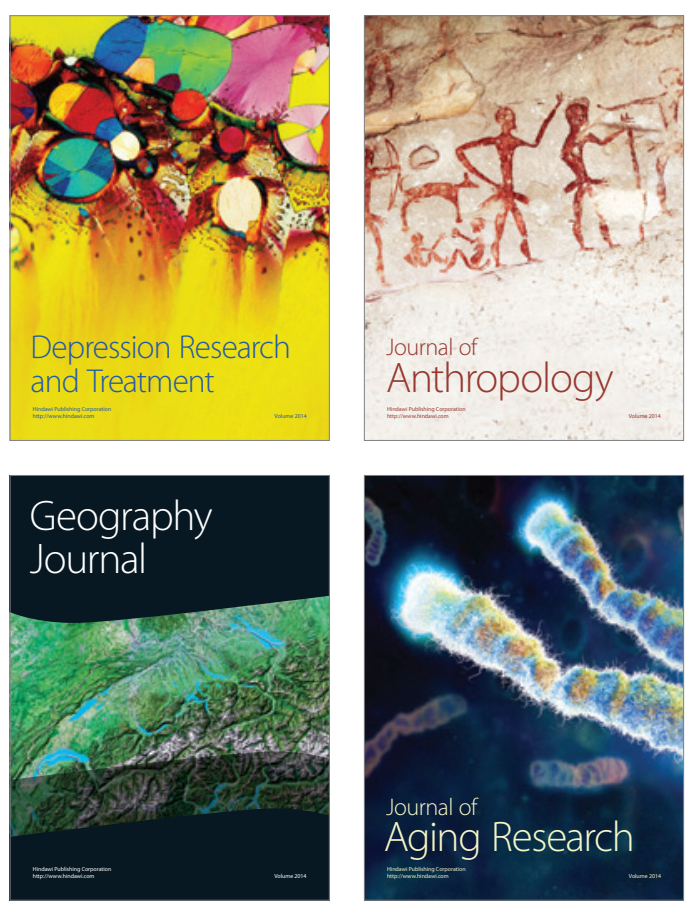
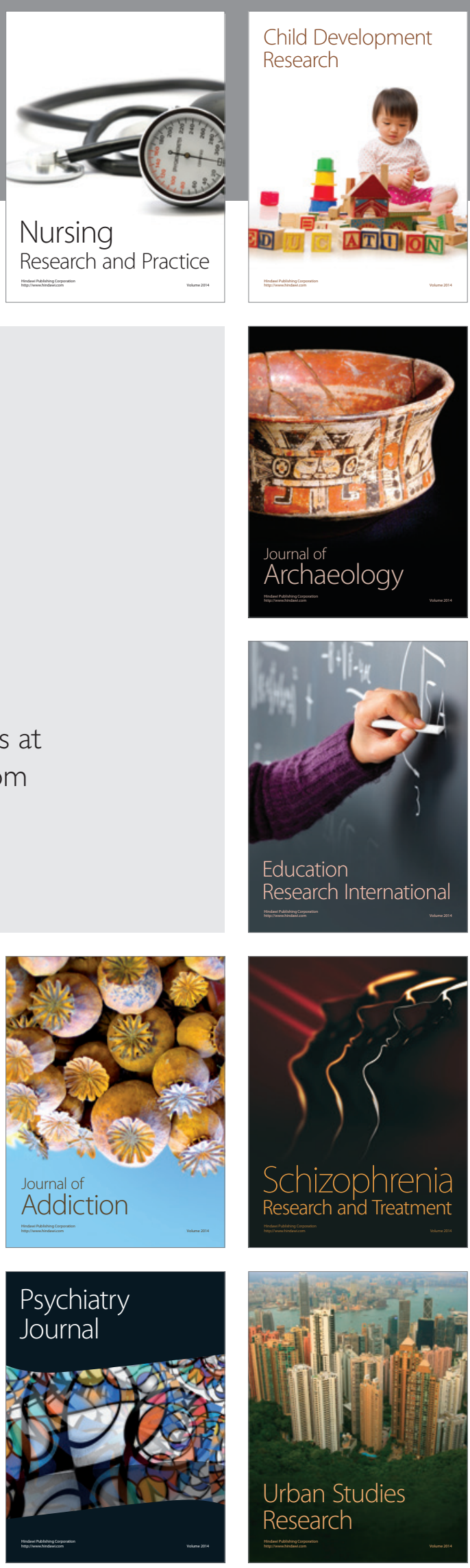